\title{
THE MYTH OF THE HIPPO-LIKE ANTHRACOTHERE: THE ETERNAL PROBLEM OF HOMOLOGY AND CONVERGENCE
}

\author{
Martin PICKFORD \\ Collège de France, and Département Histoire de la Terre, UMR 5143 du CNRS, \\ Case postale 38, 57 rue Cuvier, 75005, Paris. e-mail: pickford@mnhn.fr
}

Pickford, M. 2008. The myth of the hippo-like anthracothere: The eternal problem of homology and convergence. [El mito de la similitud entre antracoterios e hipopótamos: el eterno problema entre homología y convergencia.] Revista Española de Paleontología, 23 (1), 31-90. ISSN 0213-6937.

\begin{abstract}
The notion that anthracotheres had hippo-like body proportions, locomotion and lifestyles has been in the literature for so long, and has been repeated so many times, that it has taken on the aura of unquestionable truth. However, right from the beginning of studies into hippo-anthracothere relationships over a century and a half ago, observations were made that revealed the existence of fundamental differences in dental, cranial and postcranial anatomy in the two groups. From 1836 to 1991 two skeletal characters (a descending plate at the angle of the mandible, and raised orbits) have overshadowed all others in suggesting close relationships between hippos and a single anthracothere genus (Merycopotamus) later to be joined by a second genus, Libycosaurus, in 1991 for the descending angle, and 2003 for the raised orbits (Lihoreau, 2003; Pickford, 1991). Close examination of these structures reveals that they are not homologous in the two groups, yet they have played an inordinately stubborn role in interpretations of the relationships between them, featuring in papers as recently as 2005 . The rest of the skeleton and many cranio-dental features revealed, as early as 1836, that anthracotheres did not look particularly similar to hippos, either in gross body plan, or in details of the skeletal anatomy, observations that have been confirmed at irregular intervals ever since. Yet, despite the divergent morphology, most authors continued to attribute hippo-like locomotion, behaviour and ecology to the anthracotheres that they studied, whether anthracotheriines or bothriodontines.

Two broad themes have run side by side in the long history of study of hippo-anthracothere relationships, «homology versus convergence» and «early versus late divergence», early divergence implying the existence of a ghost proto-hippo lineage of some 30 million years duration. Indeed these two themes are linked together, in the sense that proponents of early divergence have tended to interpret the similarities between hippos and anthracotheres as convergences, whereas those who have proposed late divergence usually took the perceived similarities to represent homologies.

All these interpretations were played out within the context of a much broader background debate about monophyly or paraphyly of the artiodactyls, which was actively discussed in the Victorian era just as it is today. More recently, molecular studies have altered the scope of the debate, principally by indicating closer affinities between whales and hippos than between hippos and other artiodactyls. In the search for the ghost lineage that should link hippos to whales, some authors have recently suggested that anthracotheres fill the role «robustly», whereas others have suggested that anthracotheres are not closely related to hippos, whilst yet others have proposed that palaeochoerids or cebochoerids may represent the missing lineage. The aim of this paper is to review the possible role of anthracotheres in the evolution of hippopotamids. It is concluded that they played no part in it, whereas palaeochoerids could well represent the ghost lineage that has evaded scientists for more than a century.
\end{abstract}

Keywords: Hippopotamidae, Anthracotheriidae, Palaeochoeridae, evolution, homology, convergence, early/late divergence, history, phylogeny.

\section{RESUMEN}

La idea de que los antracoterios tienen proporciones, locomoción y modo de vida similar a los hipopótamos se encuentra desde hace tiempo en la bibliografía, y se ha repetido en tantas ocasiones que ha alcanzado un aura de verdad incontestable. Sin embargo, desde el inicio de los estudios de las relaciones entre hipopótamos y antraco- 
terios, hace más de 150 años, las observaciones realizadas han revelado que existían diferencias fundamentales entre ambos grupos en la anatomía dental, craneal y postcraneal. Desde 1836 a 1991 dos caracteres esqueléticos (rama mandibular prolongada inferiormente en su ángulo y órbitas elevadas) han obscurecido a todos los demás a la hora de sugerir la proximidad entre hipopótamos y un único género de antracoterios (Merycopotamus), al que después se le ha unido un segundo género, (Libycosaurus), por la prolongación inferior del ángulo de la mandíbula (Pickford, 1991) y por las órbitas elevadas (Lihoreau, 2003). El examen detallado de estas estructuras revelan que nos son homólogas en estos dos grupos, aunque de manera constante hayan jugado un importante papel en las interpretaciones de las relaciones entre ambos grupos, figurando incluso en trabajos del año 2005. El resto del esqueleto y muchos caracteres craneodentales conocidos ya desde 1836 revelan que los antracoterios no son particularmente semejantes a los hipopótamos, ni en la morfología corporal gruesa ni en detalles de la anatomía esquelética; estas observaciones se han confirmado repetidas veces desde entonces. A pesar de esta morfología divergente todavía hay numerosos autores que continúan atribuyendo a los antracoterios, sean antracoterinos o botriodontinos, una locomoción, comportamiento y ecología similar a los hipopótamos.

Dos ideas principales han ido paralelas a lo largo de la historia de los estudios sobre las relaciones entre hipopótamos y antracoterios, "homología versus convergencia" y "divergencia temprana versus divergencia tardía"; una divergencia temprana implicaría la existencia de un linaje proto-hipopótamo fantasma, con una duración de unos 30 millones de años. Señalar que estas dos ideas están muy ligadas, en el sentido de que los que propugnan una divergencia temprana tienden a interpretar las similitudes entre hipopótamos y antracoterios como convergencias, mientras aquellos quienes propugnan una divergencia tardía usualmente consideran las similitudes percibidas como homologías.

Todas estas interpretaciones también juegan un papel muy importante en un contexto mucho más amplio del debate sobre la monofilia o parafilia de los artiodáctilos, que se viene discutiendo activamente desde la era Victoriana hasta la actualidad. Recientemente, los estudios moleculares han alterado el ámbito del debate, principalmente al señalar una mayor afinidad entre las ballenas y los hipopótamos que entre éstos y los artiodáctilos. En la búsqueda de este linaje fantasma que debería enlazar hipopótamos y ballenas, algunos autores han sugerido que los antracoterios no tendrían una relación cercana con los hipopótamos, mientras otros sugieren que los paleoquéridos o ceboquéridos podrían representar el linaje perdido. La idea de este trabajo es revisar el posible rol jugado por los antracoterios en la evolución de los hipopotámidos. La conclusión es que los antracoterios no juegan ningún papel en ella, además los paleoquéridos bien podrían representar el linaje fantasma, que se ha evadido a las pesquisas de los científicos durante más de un siglo.

\section{Palabras clave: Hippopotamidae, Anthracotheriidae, Paleochoeridae, evolución, homología, convergencia, divergencia temprana/tardía, historia, filogenia.}

\section{INTRODUCTION}

The origin of Hippopotamidae has been the subject of enquiry for more than a century and a half, yet at the beginning of the 21 st Century it is still a matter for lively debate. Once it was realised that pachyderms [an early concept (Cuvier, 1822) linking divergent mammalian groups on the basis of their thick skin] in which hippos were once classified, was not a natural grouping (or clade) the family Hippopotamidae has been included in the Order Artiodactyla (or conceptual precursors of this order such as Paridigitata) on account of its even toed acropodes, double-trochleated talus, the keeled occipital condyles and the presence of a three-lophed $\mathrm{d} / 4$ in the milk dentition, and usually within the Suborder Suiformes because of its pig-like talar anatomy, bunodont cheek teeth and non-ruminating digestive system.

Recent molecular work has stimulated interest in the family because the analyses suggest that hippos have molecular signatures that are closer to those of whales than to those of other artiodactyls, including other Suiformes.
Underpinning the long debate about hippopotamid origins is the enduring uncertainty about the monophyly of the Order Artiodactyla. In the Victorian era, the debate was lively, although not couched in the same terms that we would use today. Nevertheless, much of the literature of the period reveals that many fossil artiodactyls did not fit into the two broadly accepted suborders - Suiformes and Ruminantia -into which extant forms could be classified. Because of this researchers tended to look for evidence to link their fossils either with the ruminants or with the suiforms [groups such as Pachysimia (eg Lydekker, 1883) which were for a time linked with Artiodactyla, are no longer recognised as being valid - genera such as Cebochoerus Gervais, 1848, formerly classed within them have been absorbed into the Suiformes]. Hippopotamidae were classified by most workers in Suiformes (or variants of the same, such as Suina) clearly distinguished from Ruminantia by the talar morphology among other features (dentition, cranial morphology, non-ruminating stomach).

The challenge of hippo-whale relationships was taken up by Boisserie et al. (2005a, 2005b) who postulated that 
anthracotheres, in particular bothriodonts, represent the ghost lineage linking the base of the whale radiation (ca $55 \mathrm{Ma}$ ) to that of the hippos (ca $15 \mathrm{Ma}$ ). Two characters in particular (raised orbit and descending angle of the jaw) featured prominently in these papers, just as they did in publications by Lydekker $(1876,1883)$ more than a century ago. However, Boisserie (pers. comm. 2006) agrees that these two characters are not synapomorphies shared by hippos and anthracotheres, and that they should no longer be used as such in cladistic analyses.

The history of interpretations of the Artiodactyla is extremely complicated, mainly because the order is rich in species and has a lengthy fossil record (ca 55 million years) and is geographically widespread (all continents except Antarctica and Australia) (Matthew, 1934). Since molecular biologists entered the arena, the diversity of interpretations has increased.

The Victorian view of a rather clearcut subdivision of living Artiodactyla into two broad subgroups (ruminants and non-ruminants) (Kowalevsky, 1874; Lydekker, 1883) was rendered less evident once fossils were included, because there were some groups, notably the anthracotheres, that showed a puzzling mixture of characters, some such as the talar morphology suggesting affinities to Suiformes, others such as the selenodont dentition indicating relationships to Ruminantia (Lydekker, 1883). For a while the intermediate nature of anthracotheres was taken by those who considered Artiodactyla to be monophyletic, as evidence that they linked the Suiformes to the Ruminantia (Lydekker, 1883) thereby supporting their hypothesis of monophyly, but others such as Kowalevsky $(1873,1874)$ considered that the Suiformes (his Paridigitata bunodonta or Suina) and Ruminantia (his Paridigitata selenodonta) diverged before the Eocene (note that at the time, the Eocene was considered to be preceded immediately by the Cretaceous and succeeded by the Miocene) (Fig. 1). This led Lydekker (1877) to comment that «according to Kowalevsky's plan of evolution there can have been no connection between the original stocks of Hippopotamus Linnaeus, 1758, and Merycopotamus Falconer \& Cautley,

\section{Paridigitata selenodonta}

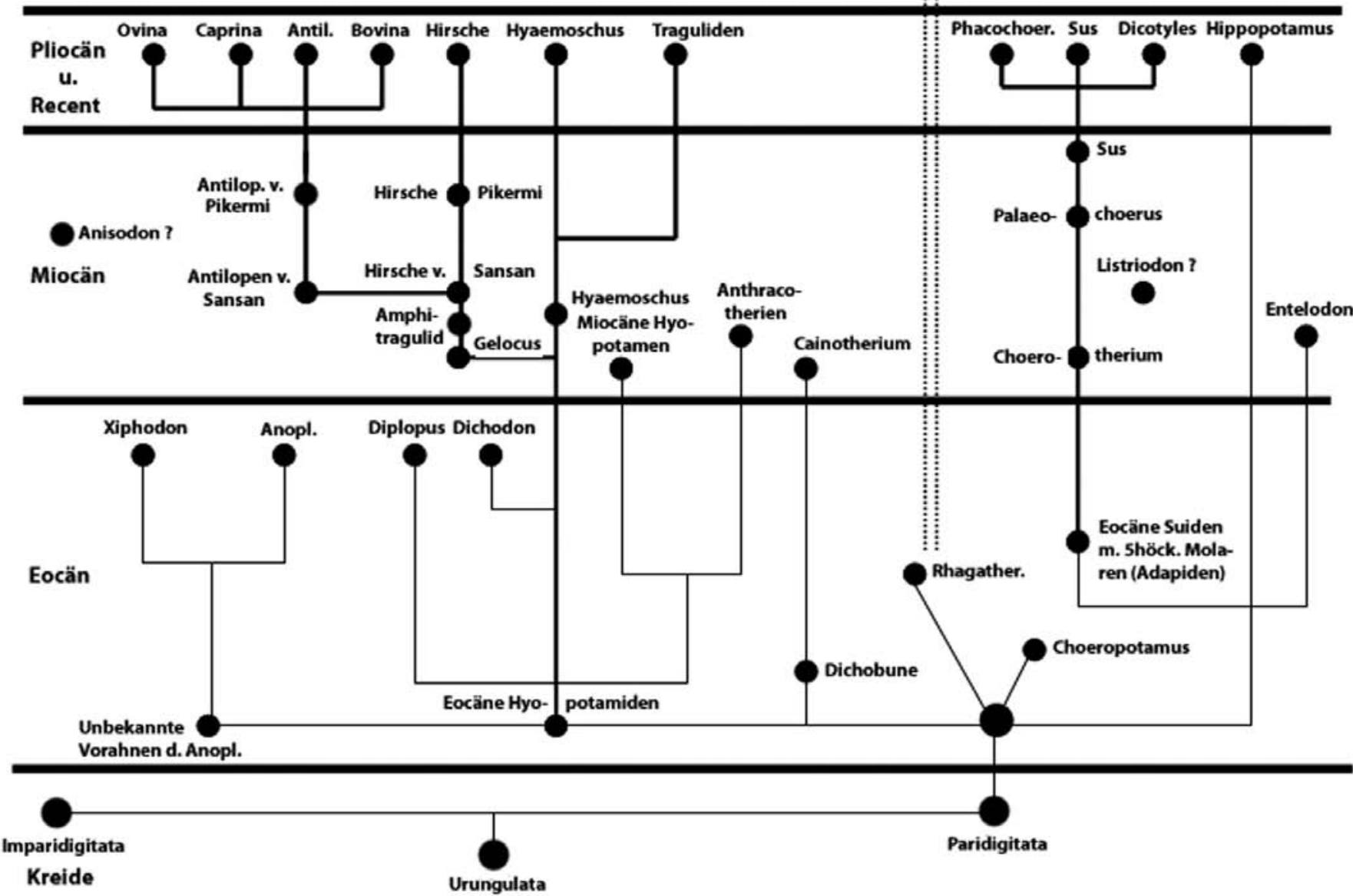

Figure 1. Artiodactyl phylogeny published by Kowalevsky (1874). In the interests of clarity, I have omitted the Imparidigitata (perissodactyls) and some of the morphological comments. 
1848, since the lower Eocene period». Lydekker (1876, 1883) envisaged a much closer «cousinship» as he put it, linking these genera as recently as the end of the Miocene or even the Pliocene. The geologically youthful linking of these genera has recently resurfaced (Boisserie \& Lihoreau, 2006; Boisserie et al. 2005a, 2005b) but the phylogenetic context has changed. In the latest scenario, the anthracotheres were envisaged as representing the missing link between Cetacea and Hippopotamidae, with other artiodactyls considered as outgroups of a HippoWhale clade within Cetartiodactyla (combined Cetacea and Artiodactyla).

It is within this changing panorama of artiodactyl phylogeny that researchers have endeavoured to resolve the issue of hippopotamid origins. It is not only the concepts and contents of the Order Artiodactyla that have changed over the years, but also the concepts and contents of lower rank groups such as families within it. The family Suidae provides a fine example. In the early part of the last century, Matthew $(1929 b, 1934)$ wrote that hippos certainly did not descend from anthracotheres but from Suidae. At the time of his writing the family Suidae was an amalgam of what we would today classify into four or five different families [Suidae (sensu stricto), Tayassuidae (New World Peccaries), Sanitheriidae and Palaeochoeridae (Old World Peccaries), and possibly Cebochoeridae depending on how one reads his 1934 chart]. Even though Matthew has been credited with the suid hypothesis of hippo origins (Colbert, 1935) detailed reading of his works indicate that he envisaged a closer relationship between North American Oligo-Miocene peccaries and hippos than between true pigs and hippos, although his 1934 chart is not consistent with his $1929 \mathrm{~b}$ text. This did not prevent subsequent authors from comparing hippos only with pigs and anthracotheres (Colbert, 1935) just as Lydekker (1876) had done before him, neglecting the Oligo-Miocene peccaries and other suoids, thereby compromising their research efforts, and as a result producing incomplete comparisons and flawed results.

Since the advent of cladistics, it has become evident, if it weren't before, that sample choice is of primordial importance for any phylogenetic analysis. The problem of missing taxa and missing data (of included taxa) is universal, and renders all phylogenetic analyses liable to modification. Thus Colbert's (1935) analysis of hippopotamid origins was bound to fail, because he did not include all the relevant groups in his study. Recent propositions by Boisserie et al. (2005a, 2005b) are compromised for much the same reason, the Palaeochoeridae (although not named as such) in their analyses being represented by a single genus, for which more than $22 \%$ of the characters analysed could not be scored, while the post-cranial skeleton was represented by only the talus and the distal metapodials.

\section{MATERIALS AND METHODS}

This examination of the relationships between hippopotamids, palaeochoerids and anthracotheres is based on comparative osteology and odontology, but because the palaeochoerids and anthracotheres are extinct, it mentions only briefly the debate concerning the place of hippopotamids in the Cetartiodactyla based on molecular analyses. The approach is basically historical and summarises the various hypotheses of hippopotamid origins and the evidence used to support those hypotheses.

\section{A WORD ABOUT Palaeochoerus AND THE FAMILY PALAEOCHOERIDAE}

The attribution of certain fossils from St-Gérand-lePuy, Allier, France, to the genus Palaeochoerus erected by Pomel (1847) has caused unending problems which still bedevil the interpretation of the suoid fossil record. In effect, there are at least two genera of pig-like suoids at the locality (Orliac, pers. comm. suggests that there are four suoid taxa at the site) a small form with two cusps in the upper $\mathrm{P} 4 /$, no pentacone in the $\mathrm{M} 3$ / and no ridges on the anterior aspect of the distal metapodial epiphysis. These are genuine Palaeochoerus by definition (see discussion in Ginsburg, 1974). In contrast the larger fossils with tricuspid P4/s, M3/s with a pentacone, and distal metapodial epiphyses with a well developed anterior crest belong to Hyotherium Von Meyer, 1834. Both Kowalevsky (1874) and Pearson (1927) and many other researchers (see a partial list in Van der Made, 1996) failed to notice the misattribution of these fossils, as did Viret (1961) who even erroneously identified the large skull of Hyotherium as the type specimen of Palaeochoerus typus Pomel, 1847. It wasn't until Ginsburg's (1974) publication that the confusion was clarified, although his correction passed almost unnoticed because it is hidden in the general discussion of his paper. Van der Made (1996) erroneously includes Ginsburg's (1974) paper among those that failed to make the distinction, despite the fact that his was the first paper since Pomel (1847) to correctly identify the skull. The confusion has proved remarkably difficult to eradicate as it is still present in papers by Boisserie et al. (2005a, 2005b).

Matthew (1924) erected the subfamily Palaeochoerinae for a subgroup of Suidae comprising Palaeochoerus from Europe, and Perchoerus Leidy, 1869, Thinohyus Marsh, 1875, Bothrolabis Cope, 1888, and Chaenohyus Cope, 1879, from America. This name initially failed to make any impact for two reasons. Firstly, New World Peccaries were already classified in Tayassuidae (Palmer, 1897) or Dicotylidae (Gray, 1868) depending on the researcher, and secondly, most scientists considered that Palaeochoerus was a suid, being confused by the mix-up in the material from St-Gérand-le-Puy, as explained above. Naturally, interpretation of Palaeochoeridae will differ if 


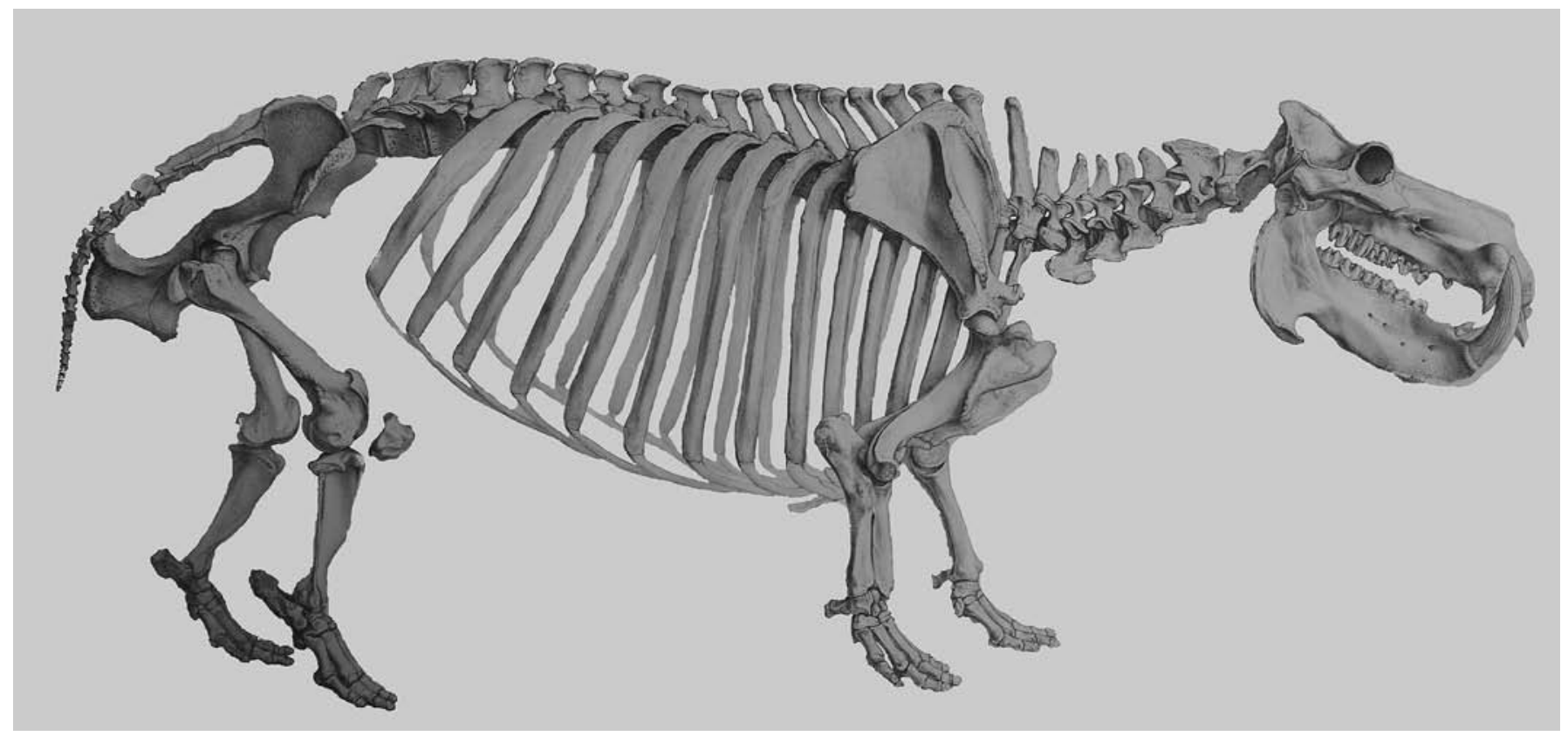

Figure 2. Lateral view of skeleton of Hippopotamus Linnaeus, 1758, showing the deep barrel-shaped thorax and the short limbs (modified from de Blainville, 1846).

one includes the skull and postcranials of Hyotherium in it or excludes them.

Van der Made $(1996,1997)$ resurrected the name, raising it to family rank (Palaeochoeridae) but he excluded the North American taxa from it.

\section{A WORD ABOUT AMPHIBIOUS ADAPTATIONS OF HIPPOPOTAMIDS AND THE IMPORTANCE OF POST-CRANIAL BONES}

Kowalevsky (1874) Lydekker (1876) and Matthew (1929a) were all of the opinion that for gaining an understanding into the relationships between artiodactyl genera, it was essential to examine the post-cranial skeleton. The main interest in the post-cranial bones, apart from the evidence they provide of a systematic nature, lies in what they can reveal about body proportions and locomotor repertoires as was shown by Kowalevsky (1874) for the Anthracotheriinae, Geais (1934) for the bothriodontine anthracotheres, and Boekschoten \& Sondaar (1966, 1972), Houtekamer \& Sondaar (1979) and Spaan (1996) for the hippopotamids.

Hippopotamids possess a unique set of features of the post-cranial skeleton and soft anatomy linked to their amphibious lifestyle, which requires that they move efficiently in water as well as on dry land. On the one hand their limbs and body show adaptations for terrestrial locomotion of up to several $\mathrm{km}$ per night while they forage and on the other they show adaptations for streamlining the body and limbs for efficient aquatic locomotion. In order to minimise the effects of drag, hippos have developed a unique body plan in which the body is barrel-shaped with such a deep rib cage that the humerus does not extend downwards beyond the ribs, but lies alongside them (Fig. 2). The humerus thus has skin covering only its lateral side, the medial part being entirely within the body. Indeed, in adults even the proximal part of the radio-ulna is within the body when the forearm is in flexed positions (Figs 3, 4). During swimming, the joints of the fore limb are hyperflexed onto each other to such an extent that the

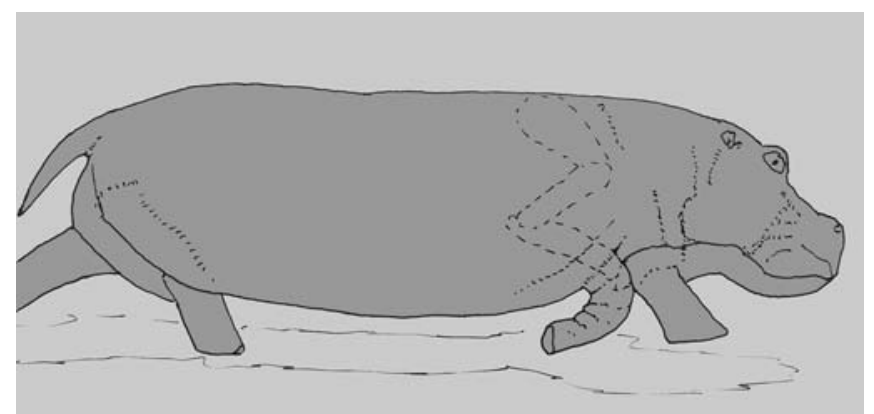

Figure 3. Hippopotamus amphibius Linnaeus, 1758, swimming. Note the position of the humerus and the proximal end of the radio-ulna retracted into the region of the thorax (the elongated appearance of the body is due to optical distortion by the lens of the camera). 


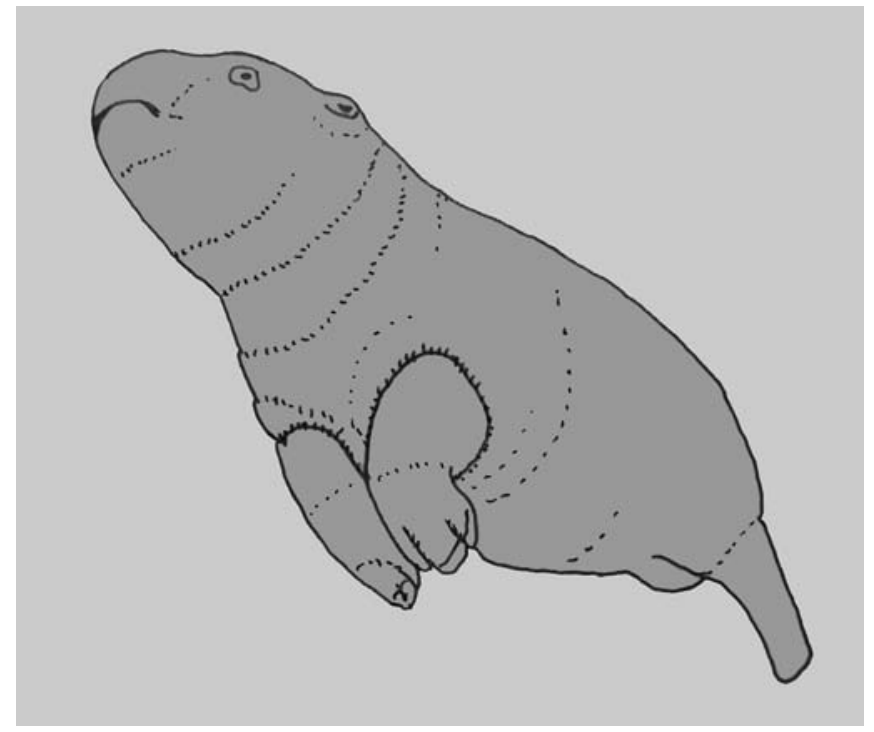

Figure 4. Choeropsis liberiensis (Morton, 1849) swimming. Note the fully retracted humerus and proximal radio-ulna, and the hyper-flexed metapodials and feet of the forelimbs as well as the streamlined positioning of the hind limbs, all of which minimise drag.

proximal half of the radius and ulna are withdrawn into the body around a deep fold in the skin, leaving only the distal part outside but held close to the rib cage beneath the neck, with the carpals, metapodials and phalanges folded back beneath, thereby reducing their coefficient of drag to a minimum (Figs 3,4). The hind limbs do not pose a significant streamlining problem, because during underwater swimming, they are pointed backwards in line with the rear of the barrel-shaped body. However, the femur is largely enveloped in a fold of skin that continues the profile of the side of the body, so that when the leg is swung forwards during underwater walking or swimming, only the distal part of the tibia, the metapodials and phalanges are exposed to the water column (Fig. 4). This unique limb system of hippos resembles a semi-retractable undercarriage.

Furthermore, for an animal of its size and bulk, the hippopotamus is incredibly agile (Figs 3,5 ) both on land and in the water, being well known for its ability to turn 'on a dime', roll over in the water and twist and turn rapidly during ritual or real agonistic encounters with conspecifics. Hippos are however, unable to jump when on land and won't even step over low hurdles in their path. Hippos are exposed to predation in aquatic and terrestrial environments and the ability to turn rapidly is an important factor in predator avoidance.

The body of hippopotamids is slightly denser than water, but is bouyant enough that relatively minor forces are required to raise the body to the surface or to move it through the water. Hippos have been described as 'danc-

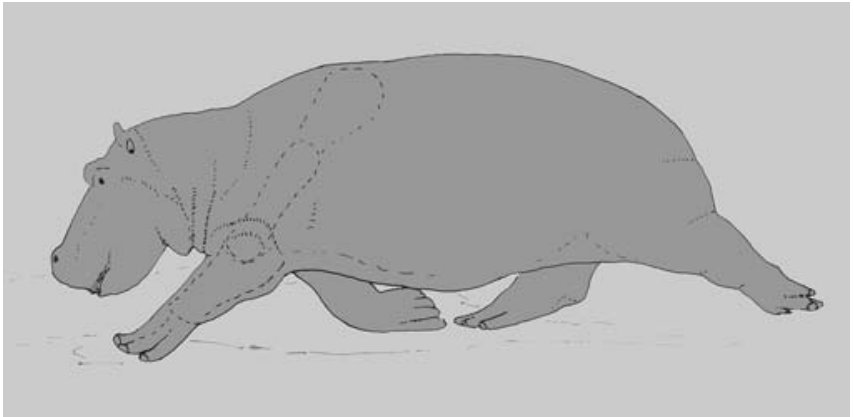

Figure 5. Hippopotamus amphibius Linnaeus, 1758, running on land. Note that even in the fully extended position, the humerus does not extend beneath the thorax.

ing' or 'gliding' above the bottom of the lakes and rivers that they inhabit, the limbs touching the ground relatively lightly to provide thrust, with the body 'floating' above the bottom (Fig. 3) often with all four legs off the ground while the body is moving forwards (Fig. 4). During «swimming», the front legs can be actively used for propulsion (broad radio-ulna, webbed foot) but foot contact with the bottom usually provides the main propulsive force.

Detailed examination of the anatomy of hippopotamid limb bones reveals that amphibious adaptations have occurred at several scales, from the overall shape and length of the diaphyses to the orientation of the articular epiphyses on the diaphyses, all of which increase the possibility of hyperflexion of the joints compared with the same joints in exclusively terrestrial artiodactyls. Other Suiformes, such as suids and anthracotheres, have proportionally longer limbs, straighter long bones with the epiphyses more in line with the diaphyses, less well developed potential for hyperflexion of the articulations, and the humerus extends well outside the body of the rib cage, and is completely surrounded by skin. In detail therefore, anthracotheres (Figs 6,7) did not have locomotor repertoires like those of hippopotamids, but more like those of suids and even some ruminants.

Given that many anthracothere fossils occur in lignites and other swamp deposits, it is possible that they lived somewhat like the extant sitatunga (Tragelaphus spekei Speke, 1863) an African bovid with comparable body proportions that spends much of its life in papyrus swamps and reed beds, foraging on dry land in the evenings, at night and in the early morning. Other ruminants with somewhat comparable habits are the Swamp Deer [Blastocerus dichotomus (Illiger, 1815)] of South America, the Sambar [Cervus unicolor (Kerr, 1792)] of India, and the Lechwe [Kobus leche (Gray, 1850)] of Africa. The major difference between these water-loving ruminants and hippos, is that they habitually keep the head and body emergent from the water, whereas hippos generally completely submerge their heads and bodies for long periods. 


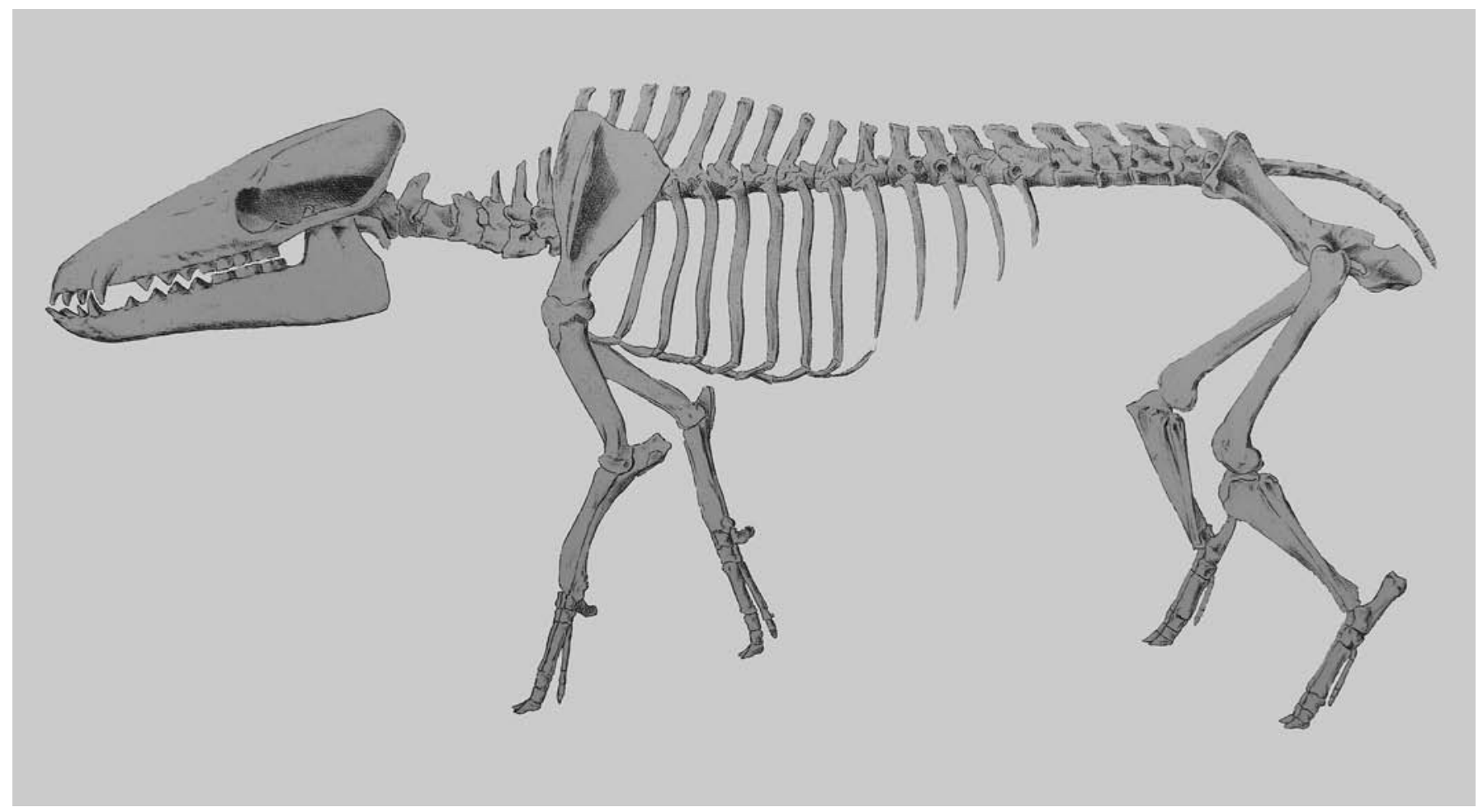

Figure 6. Anthracotherium magnum Cuvier, 1822, lateral view of skeleton, showing the elongated aspect of the limbs which extend well beneath the thorax (modified from Kowalevsky, 1874).

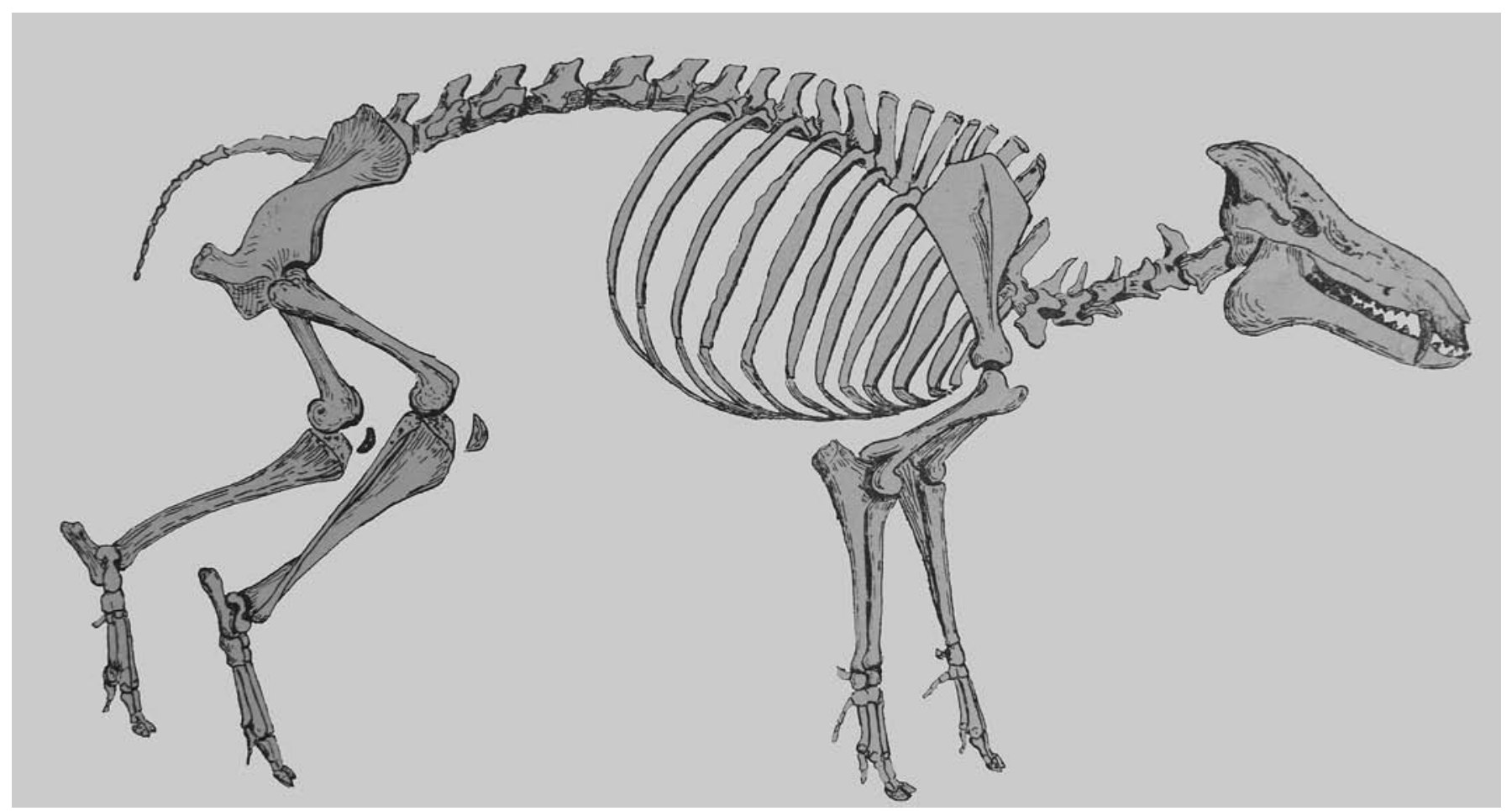

Figure 7. Elomeryx borbonicus (Gervais, 1852) lateral view of skeleton, showing the elongated aspect of the limbs which extend well beneath the thorax, as in suids and ruminants (modified from Geais, 1934). 
Even the huge Water Buffalo (Bubalus bubalis Linnaeus, 1758) of India, which has about the same dimensions as the large bothriodont, Brachyodus aequatorialis MacInnes, 1951, usually retains much of its body as well as its head emergent from the water, even when lying down in rivers and ponds.

When disturbed or threatened while in the water, Blastocerus, Cervus unicolor and Kobus leche all bound away, generally lifting the entire body well clear of the water at each bound. Hippos in contrast, when disturbed in shal- low water or on land, generally rush towards deeper water where they immediately submerge their heads and bodies completely. The strategies for dealing with danger in these two groups are thus radically different, and this is reflected in the locomotor apparatus and overall body plan. Because their post-cranial skeletons more closely resemble those of ruminants than hippos, bothriodont anthracotheres possibly behaved more like water-loving ruminants than hippos, generally keeping their bodies emergent while in shallow water, and usually avoiding deep water.

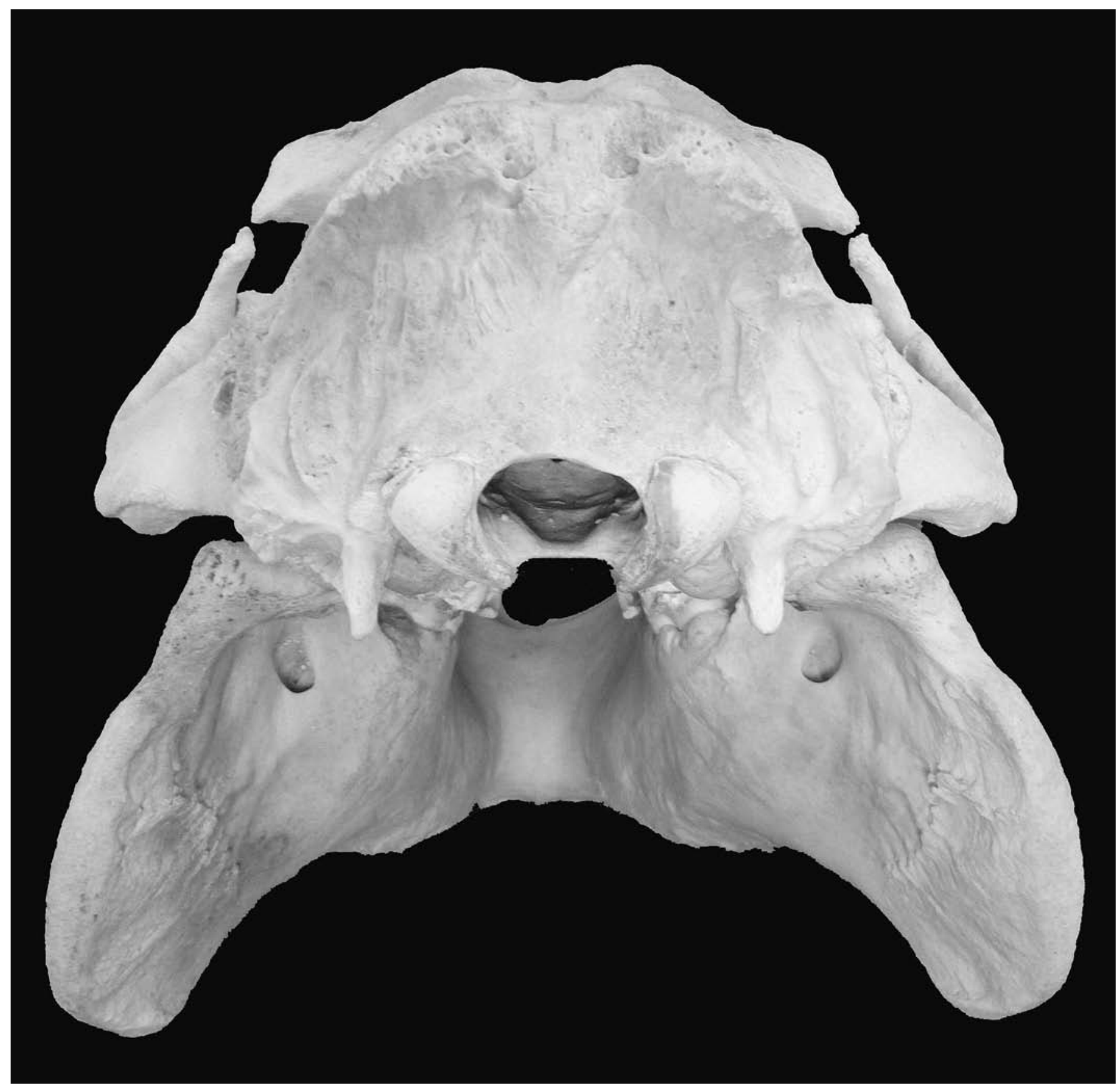

Figure 8. Choeropsis liberiensis (Morton, 1849) distal view of skull and mandible showing that the mandible is broader than the cranium, a feature unique to hippopotamids among mammals. 


\section{THE FLARED REAR OF THE MANDIBLE IN HIPPOS}

In hippos, the back of the mandibles flare laterally to a marked extent, producing a morphology unique among mammals, in that the back of the lower jaws is wider than the cranium (Fig. 8). In ventral view, the flared mandibles resemble the prow of a ship (Fig. 9) and in terms of amphibious locomotion, this peculiar morphology might play a role in reducing drag at the front of the body by streamlining the profile of the head and neck onto the barrel-like body. However, it is more likely that the flaring of the base of the mandible relates to the extraordinary gape that hippos have, especially during ritual "agonistic" or «intimidation» behaviour (inappropriately named the «yawning» display) (Fig. 10). If the distal part of the base of the two rami of the mandible were not flared, they would impinge on the neck when gape is wide, but splaying them laterally allows the jaw to be opened wide without interfering with it, the flared parts coming into position beside the neck. In extremely wide gape positions, the axis vertebra comes to lie between the upper parts of the flared plates of the lower jaw, something that would not be possible without the flaring.

\section{MOLECULAR EVIDENCE FOR AFFINITIES OF HIPPOPOTAMIDS}

During the 1990s, almost contemporary with the discovery of primitive fossil cetaceans preserving talar anatomy that suggested links between artiodactyls and whales (Thewissen et al., 1983, 1998, 2001; Gingerich et al., 2001) molecular biologists added to the debate about hippopotamid origins (Grauer \& Higgins, 1994; Xu et al., 1996; Gatesy, 1997, 1998; Gatesy et al., 1996, 1999; de Jong, 1998; Hasegawa \& Adachi, 1996; Hasegawa et al., 1997; Milinkovitch \& Thewissen, 1997; Montgelard et al., 1997a, 1997b; Shimamura et al., 1997, 1999; Milinkovitch et al., 1998; Nomura et al., 1998; Ursing \& Arnason, 1998; Kleineidam et al., 1999; Miyamoto, 1999; Nikaido et al., 1999; Nomura \& Yasue, 1999; Arnason et al., 2000, 2004; Shedlock et al., 2000; Ursing et al., 2000; Naylor \& Adams, 2001, 2003). Most molecular biologists have found the molecular evidence in support of a whale-hippo clade to be compelling, although not all morphologists agree with them (Geisler \& O’Leary, 1997; Geisler \& Luo, 1998; Luckett \& Hong, 1998; Gingerich \& Uhen, 1998; O'Leary, 1998, 1999, 2001; O'Leary \& Geisler, 1999; O'Leary \& Uhen, 1999; Gatesy \& O’Leary, 2001; Geisler, 2001; Langer, 2001; Geisler \& Uhen, 2003, 2006; O'Leary et al., 2003; Meisner et al., 2005; Theodor \& Foss, 2006). The molecular viewpoint culminated in the proposal of a Cetartiodactyla clade, the reality of which is the subject of debate, as are the details of relationships within this clade.

\section{HISTORICAL REVIEW: OSTEOLOGICAL STUDIES}

\author{
Falconer \& Cautley
}

Falconer \& Cautley (1836) were the first authors to describe fossil remains of what was eventually to be called Merycopotamus dissimilis (Falconer \& Cautley, 1836). In their initial paper they classified the fossils in the genus Hippopotamus, subgenus Hexaprotodon Falconer \& Cautley, 1836, but recognised that in some features, notably the dentition, it resembled ruminants more than hippos. They furthermore noted that the mandible was «peculiar» when compared to that of Hippopotamus, mainly in the slenderness of the ramus and the presence of a large notch between the descending plate at the angle of the jaw and the rest of the body (Fig. 11a, 12) in contrast to the «straight, thick, massive jaw» of hippos. They also noted the «elevated ridge pointing angularly forwards and pushing forward a nearly flat surface to the centre of the rear tooth» (Fig. 11a). After discussing the marked differences in breadth between the upper and lower molars, the authors closed by proposing to «establish a species with (in this respect) rather unusual peculiarities. To this smaller species we propose the name dissimilis, from the differences of form from the rest of the genus» (Hippopotamus). The authors also noted the ruminant-like narrowness of the lower molar row compared with the much broader upper molars, whereas suoids and hippos have less divergent molar row breadths.

The same authors erected the genus Merycopotamus in 1845 combining the Greek words for ruminant (merux) and river (potamos) (in Owen, 1845) but without naming a type species. Lydekker (1886) nominated the species dissimilis as the type species of the genus Merycopotamus, although the combination had been in use for some time before this publication (Falconer, 1868; Lydekker, 1876, 1883).

From these first hesitant interpretations of the fossils emerged the extremely tenacious but erroneous view that Merycopotamus was a hippo-like creature, even though Falconer \& Cautley (1836) recognised from the outset that within a hippo context it was «peculiar» and that it possessed ruminant-like features of the dentition (repeated in Owen, 1845). Falconer (1868) summarised Merycopotamus, stressing the ruminant-like aspect of the cheek dentition, contrasting with the hippo-like «cranium, incisors and canines, together with the leafy expansion of the angle of the lower jaw». His conclusion was that «Merycopotamus is a most interesting and well-marked genus, connecting Hippopotamus with Anthracotherium», a conclusion that was supported by Huxley (1871) and which echoes to this day (Boisserie et al., 2005a, 2005b). But is the skull, mandible, and anterior dentition of Merycopotamus similar to those of Hippopotamus, and if so, are the resemblances due to commonality of descent or to convergence? 


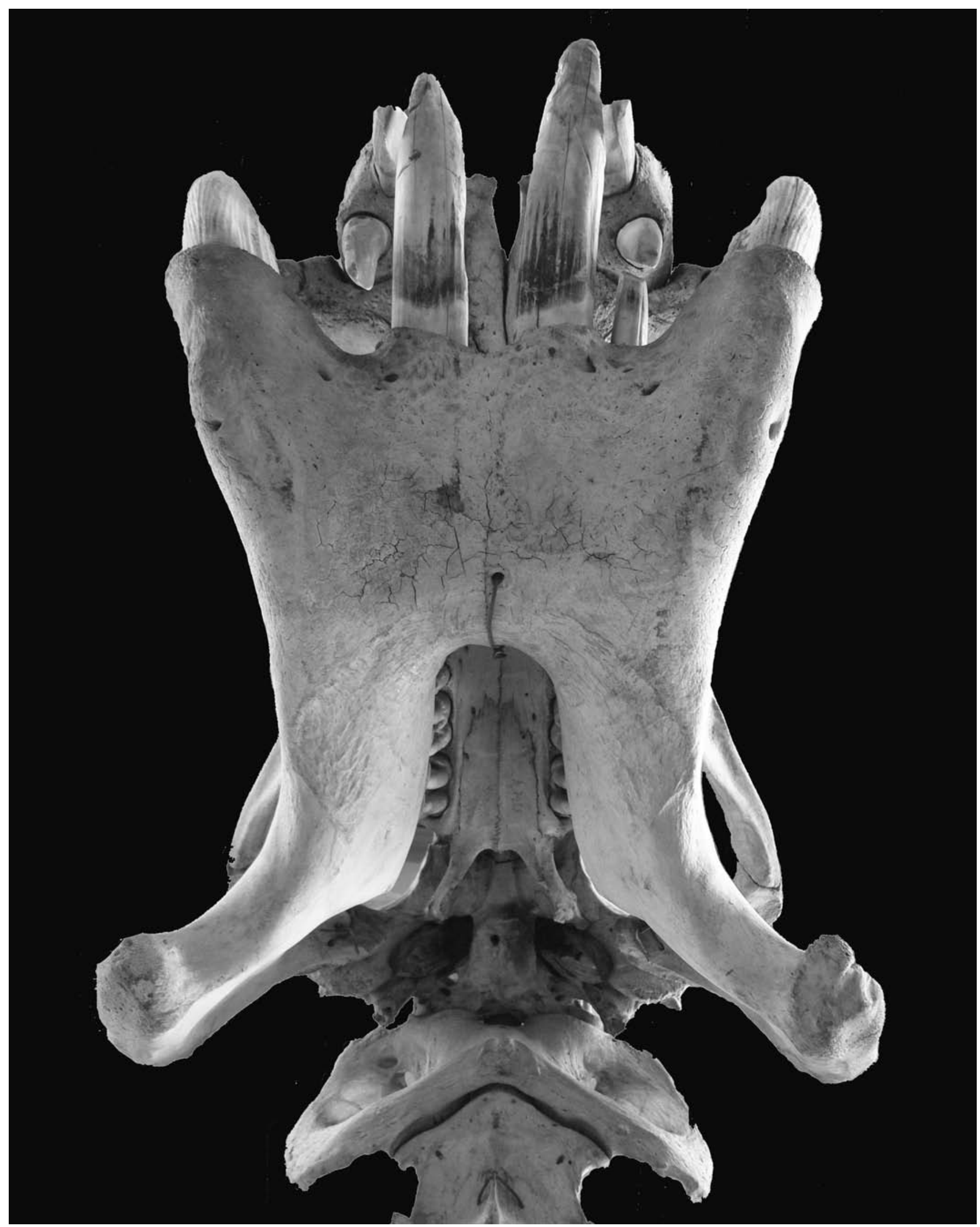

Figure 9. Hippopotamus amphibius Linnaeus, 1758, ventral view of skull and mandible showing the prow-shaped flare of the rear of the mandibles. The same morphology occurs in Choeropsis Leidy, 1853, but is unknown in anthracotheres and all other artiodactyls. 


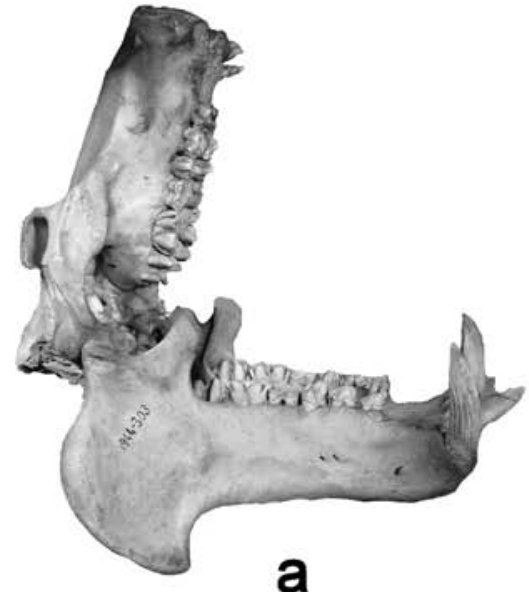

b

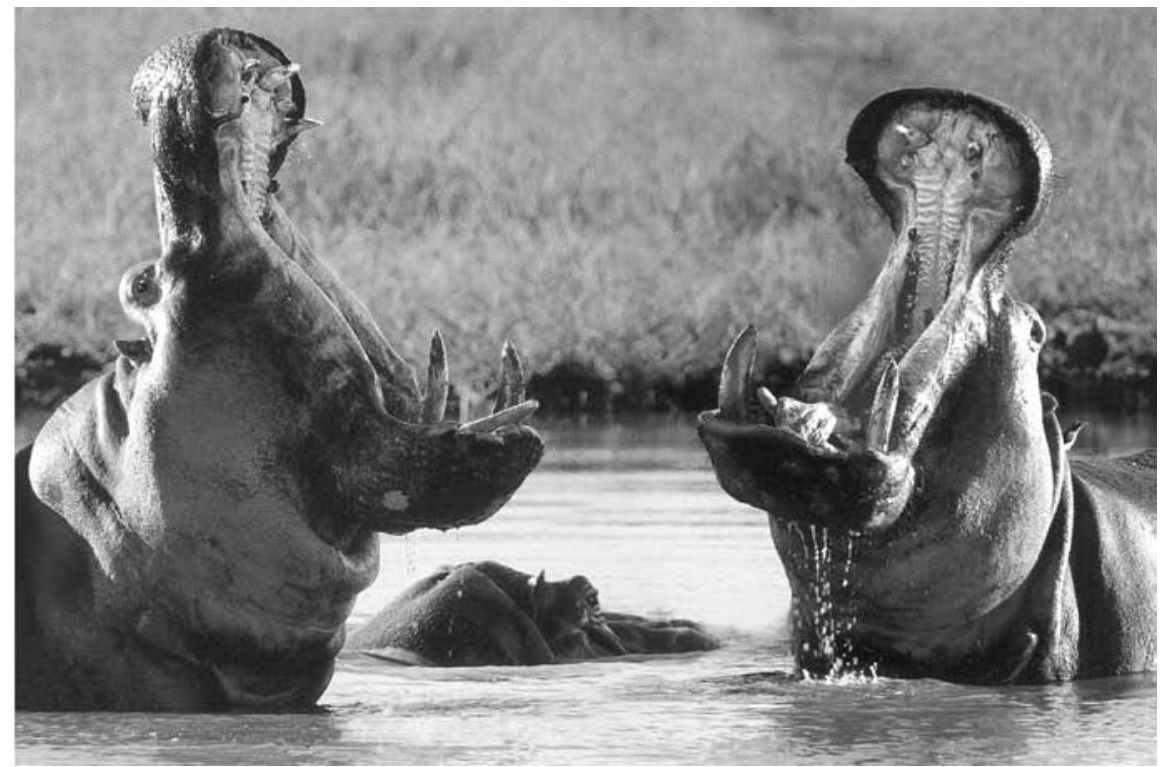

Figure 10. During the yawning display, Hippopotamus amphibius Linnaeus, 1758, opens the mouth extremely widely making a right angle between the cranium and the neck, and between the upper and lower jaws (left image skull and mandible in gape position, right image in the flesh). The live hippo on the left of the sparring pair has its jaws opened about $5-10^{\circ}$ wider than in the mounted skull and mandible.

The combination of the word potamus (Greek for river) in the generic name Merycopotamus - with its repetition in Hippopotamus - and the word dissimilis for the species, epitomises the ambivalence that has characterised interpretations of the relationship between these two taxa for over a century and a half, alternatively approaching Merycopotamus to Hippopotamus, or distancing it from it. In parallel with this phylogenetic ambivalence there has been a chronological one, those authors who approach the two genera to each other demanding a Late Miocene of Pliocene descendence of hippos from anthracotheres (Owen, 1845; Lydekker, 1876, 1883; Matthew, 1934; Boisserie et al., 2005a, 2005b) whilst those who distance the two genera from each other envisage a much more ancient dichotomy (Kowalevsky, 1873, 1874; Stehlin, 1899-1900, 1908; Pearson, 1927, 1929). The tension between early divergence and late divergence has been ever present in the study of hippo-anthracothere relationships, spiced with divergent interpretations about the polarity of the morphological characters examined.

But were the early morphological observations valid? In some instances they were, but in others they were not. For instance, Falconer \& Cautley (1836) wrote that in Hippopotamus dissimilis the cross section of the lower canine was «pear-shaped» as in Hippopotamus sivalensis Falconer \& Cautley, 1836, which strengthened their opinion that the species dissimilis was a kind of Hippopotamus. But examination of the sections of lower canines of these two species reveals that they are not the same. Hippopotamus has canines that are D-shaped, with the upright of the D (the lingual surface) concave (sometimes described as reniform or kidney-shaped). Furthermore the dentine in hippo canines is hemicentrically organised (in section looking like semi-circular onion rings, joined along a slightly curved junction between the buccal and lingual halves) (Fig. 13) and the pulp cavity is narrow except at the growing extremity. In Merycopotamus, in contrast, the lower canine section is ovoid with a distal crest, has no concavity on the lingual aspect, the dentine is massive, and the pulp cavity invades the tooth further than it does in Hippopotamus, and there is no subdivision between buccal and lingual halves. On account of their internal structure, lower canines of hippos tend to split longitudinally when they become desiccated, whereas those of Merycopotamus and other anthracotheres do not.

\section{Kowalevsky}

Kowalevsky $(1873,1874)$ published two monographs on the Anthracotheriidae, in which he made extensive comparisons of their dental, cranial and post-cranial anatomy with those of other artiodactyls. He did not enter into much detail about hippopotamid origins because he considered that the family belonged to a separate «suborder» [Paridigitata bunodonta (Suina)] from anthracotheres [Paridigitata selenodonta] and was therefore of peripheral interest to the focus of his research. In his second monograph (Kowalevsky, 1874, chart opposite p. 152) he postulated a dichotomy among primitive artiodactyls at the base of the 

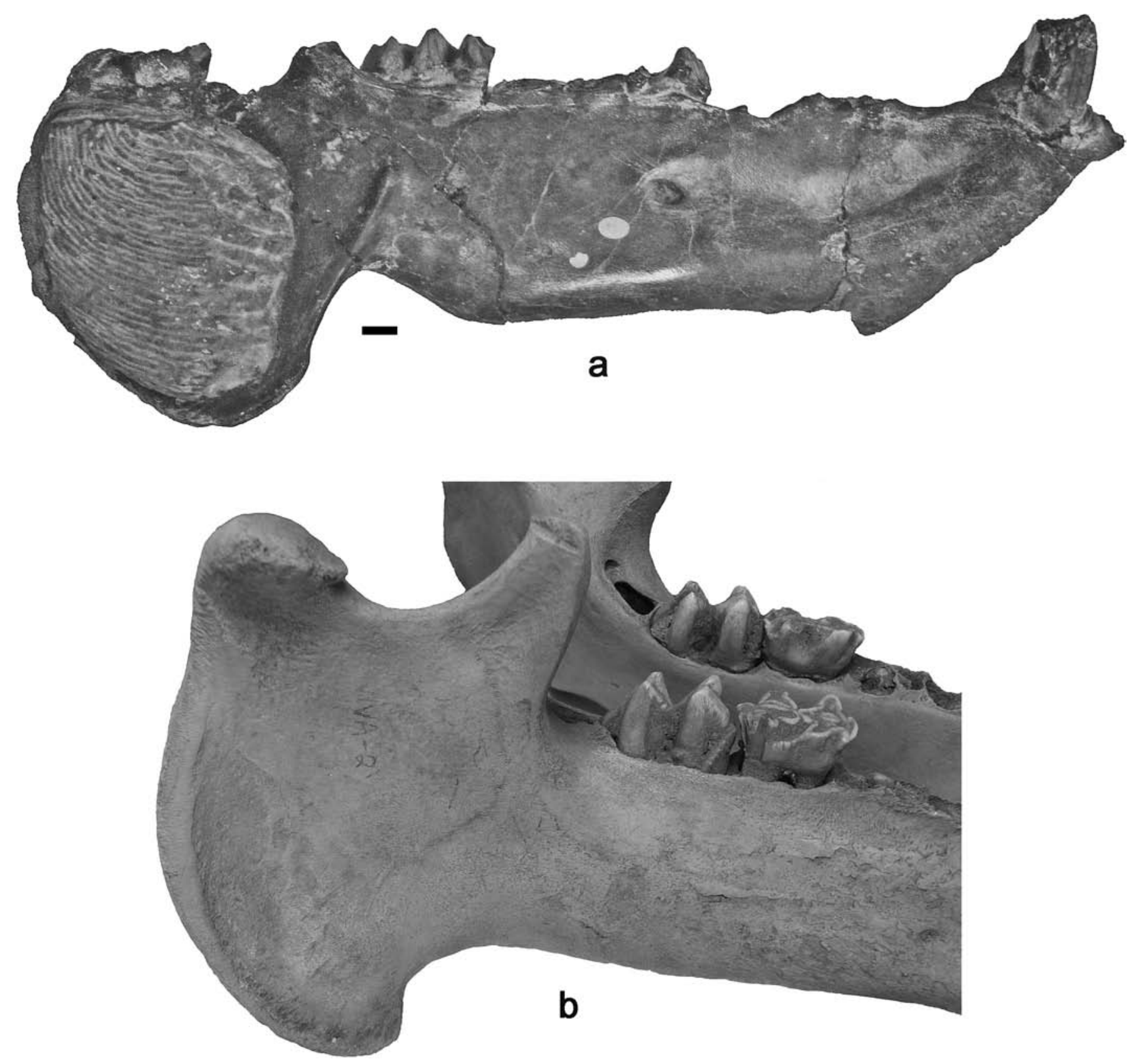

Figure 11. Mandibles of (a) Merycopotamus dissimilis (Falconer \& Cautley, 1836) showing the notch in the base of the ramus anterior to the descending plate and a well developed ridge delimiting the masseteric fossa, and (b) Hippopotamus madagascariensis Guldberg, 1883, showing absence of notch at the base of the ramus in front of the descending plate and the absence of a pre-masseteric ridge on the lateral aspect of the jaw (scale: $10 \mathrm{~mm}$ ).

Eocene, giving rise to these two «suborders». Note that at the time of his study Kowalevsky (1874) considered that the Eocene immediately succeeded the Cretaceous and that the order Paridigitata (ie Artiodactyla) originated during the Cretaceous. The Oligocene had not been recognised by the time of his work, so in his chart the Eocene is followed directly by the Miocene. His phylogenetic schema (Fig. 1) was soon criticised by Lydekker (1883) who preferred a much closer relationship between anthracotheres and hippopotamids, with the dichotomy envisaged as occurring during the Late Miocene.

It should also be noted that Kowalevsky (1873, Pl. 7) was among the first scientists to record that the metapodials of Choeromorus Gervais, 1848, from the Middle Miocene of Sansan, France, (his Choerotherium Lartet, 1851, for a while also known as Taucanamo Simpson, 1945) did not possess a ridge on the anterior aspect of the distal epiphysis. Kowalevsky (1874) accepted the status of the Pal- 


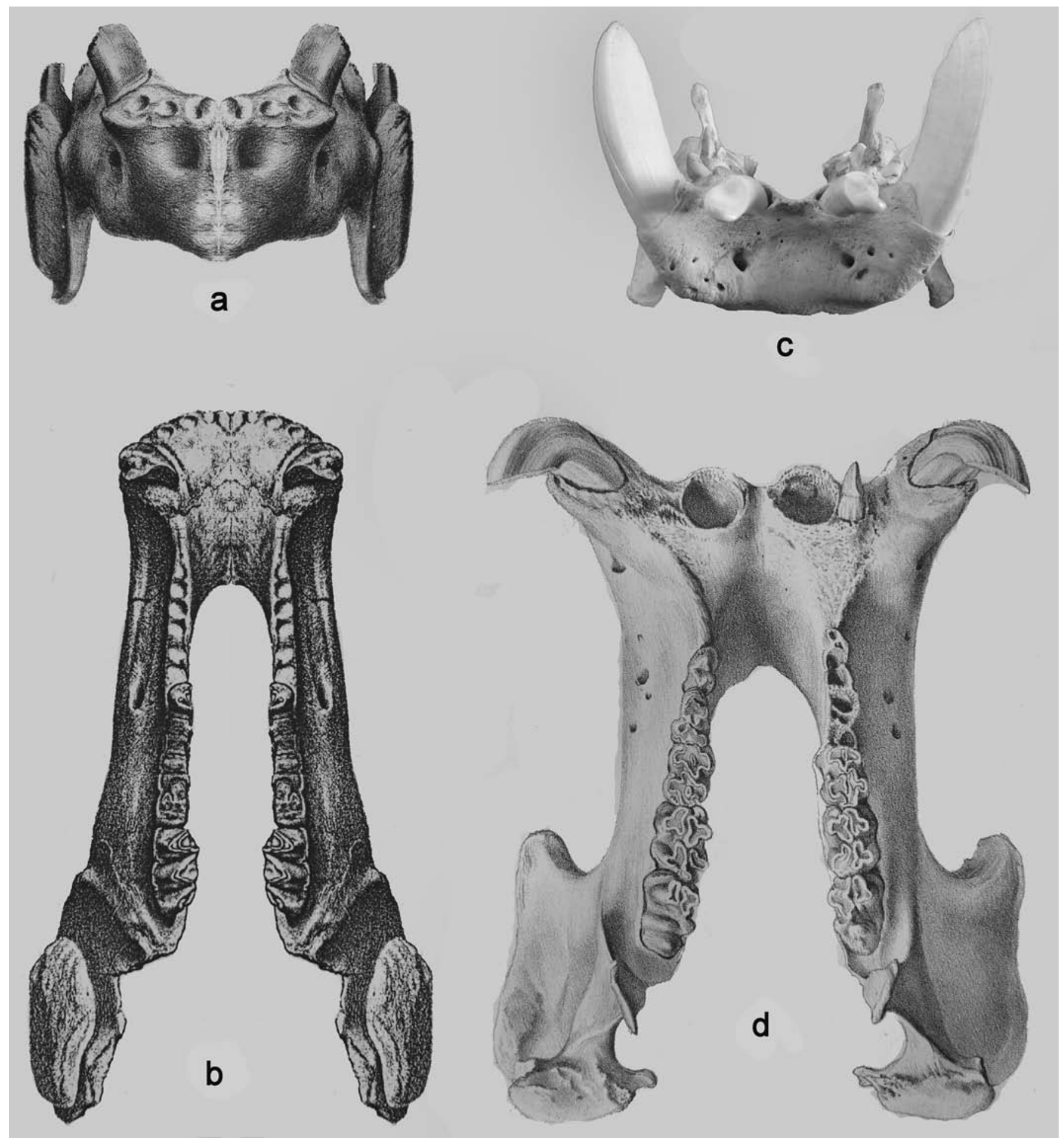

Figure 12. Anterior and dorsal views of mandibles of $(\mathrm{a}, \mathrm{b})$ Merycopotamus dissimilis (Falconer \& Cautley, 1836) showing the vertical orientation of the descending plate (modified from Falconer \& Cautley, 1848), (c) anterior view of mandible of Choeropsis liberiensis (Morton, 1849) and (d) dorsal view of mandible showing the flared orientation in Hippopotamus amphibius Linnaeus, 1758, (a) and (b) modified from Falconer \& Cautley, 1848, (d) modified from de Blainville, 1846) (not to scale).

aeochoerus Pomel, 1847, fossils from St-Gérand-le-Puy, France, unaware that some of the fossils belonged to Hyotherium. Thus the metapodials with a strongly developed ridge on the anterior aspect of the distal epiphysis that he attributed to Palaeochoerus, belong in fact to Hyotherium. This generic misattribution, like that of the skull 


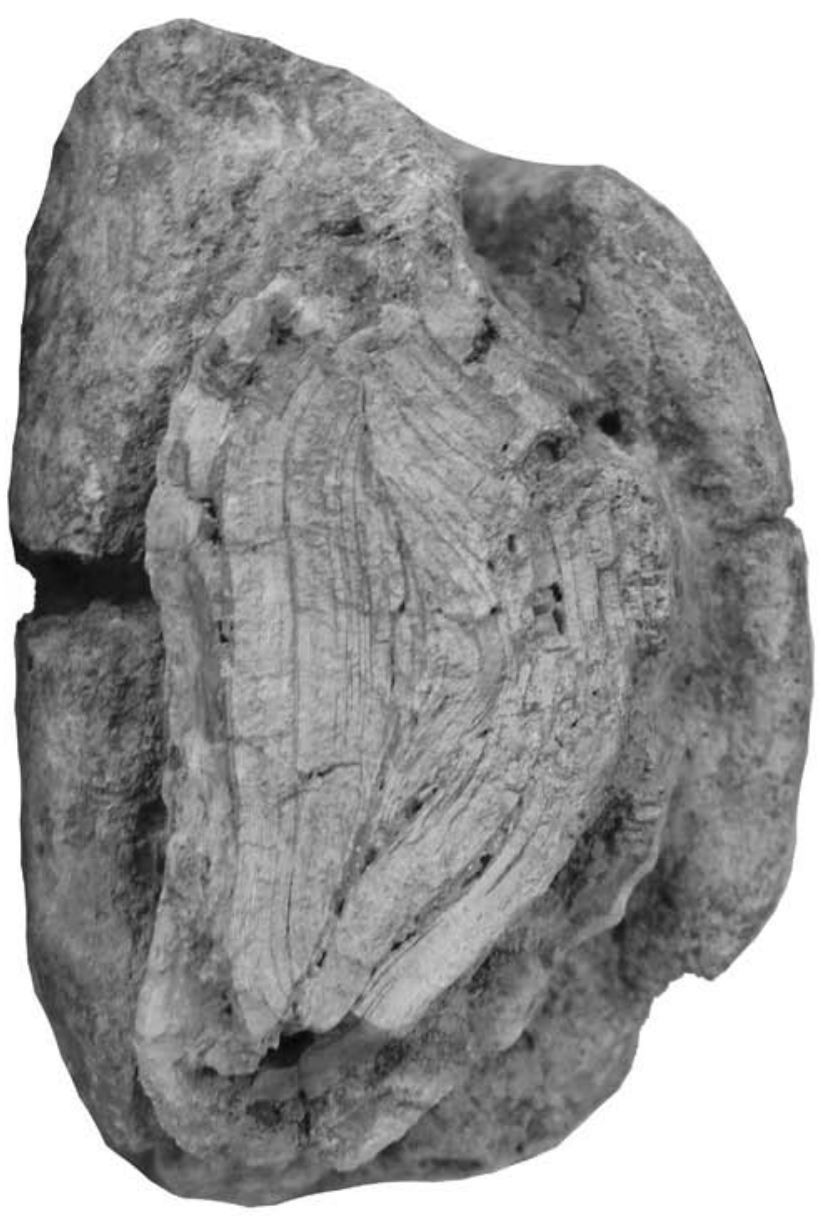

a

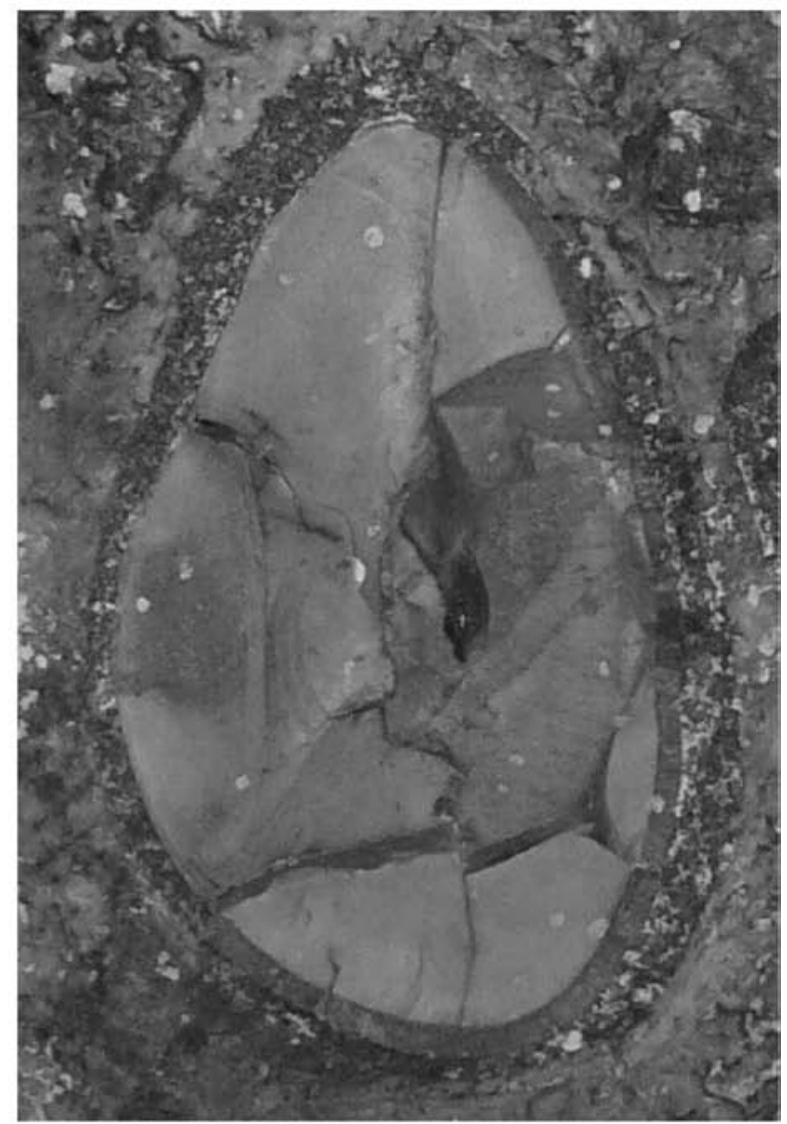

b

Figure 13. Transverse sections through lower canines of (a) Hippopotamus major Cuvier, 1804, Palermo, Italy, and (b) Merycopotamus dissimilis (Falconer \& Cautley, 1836). Note the hemicentric arrangement of the dentine in the hippo canine and the distinct curved junction between the buccal and lingual halves of the tooth in the hippo, and the massive dentine in Merycopotamus (not to scale).

of the same species (Pearson, 1927; Viret, 1961) greatly influenced interpretations of the Early Miocene suoids of Europe for more than a century (Ginsburg, 1974) and has caused an inordinate amount of confusion. Recent interpretations of the phylogenetic relationships of hippopotamids and anthracotheres (Boisserie et al., 2005a, 2005b) are affected by this misidentification.

In his 1874 paper, Kowalevsky depicted a reconstruction of the skeleton of Anthracotherium magnum Cuvier, 1822, based on fossils from La Rochette (Fig. 7). This drawing is interesting in that it shows limb proportions and thorax depth that differ markedly from those of hippopotamids. In hippos, the humerus does not emerge beyond the deep barrel-shaped thoracic mass, but is enveloped inside the thick skin that covers the body, being part of the streamlining adaptation of the animal. When in the water hippos expose only the distal half of the radio-ulna, wrist and foot outside the barrel-like body mass, thereby reducing to a minimum the effect of drag due to limb ex- posure. In the anthracotheriine Anthracotherium magnum the humerus extends clearly beneath the thoracic cage, as in suids, to such an extent that most of the humerus is visible outside the thoracic mass and when in water, it and the rest of the forelimb would have presented a large surface area with a consequently large coefficient of drag. The bothriodontine Elomeryx borbonicus (Gervais, 1852) has a similar long-limbed and slender rib cage aspect to its body plan (Geais, 1934).

\section{Lydekker}

Richard Lydekker wrote extensively on Siwalik mammals, in particular the artiodactyls. He was especially interested in the suprageneric relationships of the species that came under his investigation, the end of the 19th Century being a period during which many investigators including Huxley (1871) and Kowalevsky (1873) were research- 
ing such higher taxonomic issues. Nowadays we would describe the debate in terms of questioning whether the Artiodactyla are monophyletic or paraphyletic. Lydekker focussed in particular on the subdivision of the Artiodactyla into non-ruminating and ruminating animals. He evidently considered, like many of his contemporaries, that the former equate with the bunodont types and the latter with selenodont types, although he stressed that extinct forms were sometimes intermediate in dental morphology and thus could not be easily classified into one or other of the groups.

The comprehensive collection of anthracotheres that he had available, in particular that of Merycopotamus dissimilis from the Plio-Pleistocene Upper Siwaliks of India, posed particular problems to Lydekker, on account of the presence of what he took to be hippopotamoid features in the skull, mandible and dentition indicating to him the possibility of links to Hippopotamidae, yet showing many features that differed fundamentally from hippos, not only in the cranium, but also in the dentition and post-cranium (Table 1). His writings on the subject of the affinities of Merycopotamus and its relationships to Hippopotamus show a curious ambivalence, with the text sometimes highlighting similarities to hippos whereas the tables show Merycopotamus to be an anthracothere, well removed from the hippos, not only at the family level but also at a higher superfamilial or even subordinal level (Bunodontia versus Selenodontia for example) (Table 2).

Lydekker's publications reveal a person struggling to make sense of what we would today refer to as derived or primitive morphology (apomorphies or plesiomorphies respectively) and homology and homoplasy (similarities due respectively to common ancestry or to convergence). To Lydekker $(1876,1877)$ the exaggeratedly descending angle of the mandible in Merycopotamus, for example, represented shared derived morphology found only in Hippopotamus and Merycopotamus among the artiodactyls and thereby denoting cousinship (as he put it) between these two genera. Many subsequent authors such as Colbert (1935) concurred with Lydekker's opinion. In his detailed description of the osteology of Merycopotamus, Lyddeker (1876) compared the fossil Merycopotamus remains with extant Hippopotamus and Sus Linnaeus, 1758, and barely mentioned other artiodactyls. Colbert (1935) made a similar restricted comparison (Merycopotamus, Hippopotamus, and the suid Conohyus Pilgrim, 1925) and came to a similar conclusion, the sample analysed almost guaranteeing the result. As a consequence of the sample choice, Merycopotamus appeared to Lydekker to have greater affinities with hippos than with suids from which he was "inclined to place the genus in the family Hippopotamidae, forming a link between that and the Anthracotheridae (sic)". In subsequent publications he noted that the words "Hippopotamidae" and "Anthracotheridae" had been transposed in the 1876 paper, completely altering the conclusion by removing Merycopotamus from Hippopotamidae and classifying it in Anthracotheriidae, but being more consistent with his subsequent writings. The suprageneric categories that Lydekker was employing were at the time a subject of active debate, with very little consensus emerging about how to arrange the artiodactyls into subordinal categories, and this shows clearly in Lydekker's own results.

Superficial resemblances between Hippopotamus mandibles and those of Merycopotamus were noted as soon as fossils of the latter genus were discovered (Falconer $\&$ Cautley, 1836) which is why the discoverers initially classified the remains as Hippopotamus dissimilis. Lydekker (1876) was so impressed by the descending angle of the jaw that he repeatedly remarked on its significance, taking it to be an apomorphy shared by the two genera. However, he made a peculiar error (Lydekker, 1883) when describing the 'angle' in the mandibles of Hippopotamus and Merycopotamus, which he wrote was, in both genera, «produced into a large plate, preceded by a deep notch in the inferior border of the horizontal ramus». This notch is present in Merycopotamus (Fig. 11a) but not in Hippopotamus in which the jaw deepens beneath the $\mathrm{m} / 3$ (Fig. 11b). Furthermore, the descending plate in Merycopotamus is oriented almost vertically, not splayed out laterally as in Hippopotamus (Fig. 12) in which it is part of the adaptation for opening the jaw extremely widely during ritual displays. In Merycopotamus there is a well defined, almost rectilinear, obliquely descending ridge of bone on the lateral aspect of the mandible that is in line with the leading edge of the descending plate and its upper end points towards the middle of the $\mathrm{m} / 3$ (Falconer \& Cautley, 1836). Superiorly this ridge, which marks the anterior margin of the insertion of the masseter, terminates in the upper third of the ramus, the area above it being flat (Fig. 11a). In hippos there is no corresponding ridge of bone, the jaw being smooth in the equivalent region (Fig. 11b). These differences reveal that the derived structures of the angular region of the mandible in Merycopotamus and Hippopotamus are not homologous. The resemblances of the descending plate and its surrounding structures in the two genera are superficial, and are due to convergence rather than to commonality of descent.

Despite these rather prominent differences, already evoked by Falconer \& Cautley (1836), Lydekker (1877) evidently considered the similarities in mandibular morphology of hippos and Merycopotamus to be homologous. He wrote that "the very remarkable similarity in the form of the mandible of Hippopotamus and Merycopotamus .... admit that these two genera must have descended from some common ancestor which had a similarly shaped mandible". He mentioned that "no other pig-like animal, either recent or fossil has a similarly shaped lower jaw, though there is a very slight rudiment of the descending process in the American Peccari and Hyopotamus". Because of the supposed homology of the mandibular characters of 


\begin{tabular}{|c|c|c|}
\hline Skeletal Character & Merycopotamus & Hippopotamus \\
\hline Profile of occipital crest to nasals & evenly sloping & evenly sloping \\
\hline Depth of the upper portion of cranium & slight & slight \\
\hline Zygomatic arches & wide & wide \\
\hline Sagittal crest & deep, strong & deep, strong \\
\hline Muzzle & slightly expanded & enormously expanded \\
\hline Orbits & elevated & elevated \\
\hline Orbits & closed posteriorly & closed posteriorly \\
\hline Position of inferior portion of orbit & unusually far forwards (over M1/) & backwards (over M2/) \\
\hline Proximal extremity of nasals & low & high \\
\hline Distal extremity of nasal & acute with re-entering angle & expanded \\
\hline Facial surface of nasals & nearly flat & rounded \\
\hline Facial surface of nasals & at right angles to lateral surface of maxilla & no angle \\
\hline Nasal articulation with premaxilla & small & longer \\
\hline Premaxilla & long & short \\
\hline Naso-maxilla suture & straight & not straight \\
\hline Premaxilla overlap of facial surface of nasals & none & none \\
\hline Foramen for 5th nerve & above $\mathrm{P} 4 /$ & anteriorly positioned \\
\hline Jugal & continuous with maxilla & overhangs maxilla \\
\hline Maxillary process for articulation with jugal & none & present \\
\hline Lachrymal & elongated & different proportions \\
\hline Lachrymal foramen & single & single \\
\hline Position of lachrymal foramen & close to angle of lachrymal bone & not close to angle of lachrymal bone \\
\hline Frontals in front of orbits & expanded laterally & not expanded laterally \\
\hline Supraorbital foramen & above centre of orbits & above centre of orbits \\
\hline Hinder portion of parietals & greatly longer & short \\
\hline Sagittal crest & long & short \\
\hline Cranial and facial portions of skull & approximately equal & facial part much longer than cranial \\
\hline Temporal fossa & in line with lateral edge of orbit & inside lateral edge of orbit \\
\hline Form of occiput & close to $\mathrm{Sus}$ & unlike Sus \\
\hline Occiput breadth to height ratio & less & more \\
\hline Occipital surface of squamosal & more advanced of supraoccipital plane & less advanced of supraocciptal plane \\
\hline Median groove on basi-occiptal & absent & present \\
\hline Tubercles on basi-occiptal & absent & two present \\
\hline Tympanic bulla & larger & smaller \\
\hline Distal extension of palatines & behind M3/ & behind M3/ \\
\hline Upward bend of palato-maxillary suture & rounded & elongated \\
\hline Tooth rows & nearly parallel & diverging anteriorly \\
\hline Glenoid cavity & flat, large & large flat \\
\hline Jugal process bordering glenoid & none & none \\
\hline Posterior extremity of mandible & descending & descending \\
\hline Incisors & small & large \\
\hline Canine position & close to $\mathrm{i} / 3$ in line with molars & outside line of molars \\
\hline Canine section & trihedral & not trihedral \\
\hline Upper canine & no posterior groove & posterior groove present \\
\hline Axis vertebra & long & short \\
\hline Axis rim connecting facets for the atlas & less developed & greater development \\
\hline Axis transverse processes & slightly wider & narrower \\
\hline Femur greater trochanter & high & low \\
\hline Femur greater trochanter & recurved & straighter \\
\hline Femoral head orientation on neck & more nearly perpendicular & not perpendicular \\
\hline Femur digital fossa & deeper & shallower \\
\hline Femur distal trochlea & elongated & short \\
\hline Femur distal trochlea & parallel to long axis of bone & not parallel to long axis of bone \\
\hline Tibia, region between the two articular surfaces & notched & not notched \\
\hline Tibia posterior border of proximal end & notched & not notched \\
\hline Talus breadth/length ratio & long $(b=1 / 21)$ & short $(b=2 / 31)$ \\
\hline Talus trochlea surface for calcaneum & oblong & almost square \\
\hline Talus pit between calcanear and tibial articulations & shallower & deeper \\
\hline Calcaneum & similar & similar \\
\hline Metacarpal distal articulation & similar & similar \\
\hline Foot position relative to line separating 3 rd and 4 th digits & less symmetrical & symmetrical \\
\hline Ist phalanx & similar & similar \\
\hline Humerus greater tuberosity & less developed & more developed \\
\hline Humerus bicipital groove & unusually wide & narrower \\
\hline Humerus bicipital groove & less closed in by bone & more closed in by bone \\
\hline Deltoid ridge & strong & strong \\
\hline Posterior extension of greater tuberosity & more continuous & less continuous \\
\hline Distal humerus ridge on radial half of trochlea & more prominent & less promient \\
\hline Ulnar condyle of humerus & more prominent & less prominent \\
\hline Fusion of radio-ulna & not ankylosed & ankylosed \\
\hline Radius mid-shaft & not contracted & contracted \\
\hline Distal ulna & enlarged & enlarged \\
\hline
\end{tabular}

Table 1. Osteological comparison between Merycopotamus and Hippopotamus summarised from Lydekker (1876) (some of these characters such as orbital closure, are now known to be variable - I have summarised them as Lydekker reported). 
A - Bunodontia

1. Suidae

2. Dicotylidae

Sus, Porcula, Babirusa, Hippohyus (?), Sanitherium (1), Amphichoerus (2), Heterohyus (3),

Choeromorus (4), Potamochoerus, Palaeochoerus (5)

3. Acotherulidae

Dicotyles, Hyotherium (?) (6), Thinohyus, Platygonus

Acotherulum, Leptacotherulum

4. Phacochoeridae (7)

Phacochoerus

5. Entelodontidae

Entelodon, Tetraconodon (8), Achaenodon

6. Hippopotamidae

?

Hippopotamus, Choeropsis

Leptochoerus, Parahyus, Eohyus, Helohyus

B - Selenodontia

a. Pentacuspidati

1. Anthracotheridae (sic)

Anthracotherium, Hyopotamus, Rhagatherium, Choeropotamus, Hemichoerus

(?) 2. Mixtotheriodontidae

Mixtotherium

(?) 3. Diplopidae

b. Tetracuspidati

Diplopus

1. Merycopotamidae

2. Oreodontidae

Merycopotamus, Choeromeryx, Hemimeryx, Sivameryx (9)

c. Anoplotherina

Oreodon, Eporeodon, Agriochoerus, Merycochoerus

1. Anoplotheridae

Anoplotherium, Eurytherium, etc.

(?) II - PACHYSIMIA

Cebochoeridae

Cebochoerus

\section{III - RUMINANTIA}

Notes:

1 Sanitherium is now classified in its own family Sanitheriidae

2. Amphichoerus is no longer considered a suid.

3. Heterohyus is no longer considered a suid.

4. Choeromorus is now classed in Palaeochoeridae (for a while it was called Taucanamo).

5. Palaeochoerus is the type genus of Palaeochoeridae and is not a suid.

6. Hyotherium is now classified in Suidae.

7. Phacochoeridae is a synonym of Suidae. Phacochoerus is a suid.

8. Tetraconodon is now classified as Suidae, being the type genus of the subfamily Tetraconodontinae.

9. Sivameryx is pentacuspidate.

In addition, Lydekker (1877) noted similarities between the upper molars of the giant suid Hippopotamodon and those of Hippopotamus, hence the name of his new genus, which did not figure in his 1883 chart, although he evidently considered it to be allied to the hippos.

These changes affect the context of the comparative arguments of Lydekker outlined above.

Table 2. Lydekker's 1883 classification of the Suina relative to the Pachysimia and Ruminantia.

Hippopotamus and Merycopotamus, Lydekker (1877) was forced to question Kowalevsky's thesis that the Bunodonta separated from the Selenodonta during the Eocene, and he surmised that "the Bunodonta and Selenodonta are more closely connected than Kowalevsky supposes". Furthermore, the selenodont dentition of Merycopotamus indicated to Lydekker that its ancestor "must have been selenodont or hemi-selenodont" and therefore that "Hippopotamus is descended from a selenodont and not a bunodont ancestor" providing "an instance of reversion to an older type".
But countering this explanation in his summary, Lydekker (1877, p. 81) classed the pigs and hippopotamoids as Suina Bunodonta (sic) and the hyopotamoids (ie anthracotheres) and anoplotherioids as Suina Selenodonta (sic).

Table 1 reveals that the morphology of the postcranial skeleton of Merycopotamus is highly divergent from that of Hippopotamus except in the calcaneum, distal end of the metapodials and phalanges, and that the skull and mandible are overall rather different, but with some similar features, and the dentition is highly divergent (seleno- 
dont as opposed to bunodont, as well as in details of tooth position, incisor and canine morphology, etc). To this list should be added that the $\mathrm{p} / 1$ is close to $\mathrm{p} / 2$ in Merycopotamus and well separated from $\mathrm{p} / 2$ in Hippopotamus and that the morphology of the limb bones of Merycopotamus are nearer to those of anthracotheres, whereas those of hippos are far from anthracotheres (Lydekker, 1883).

When Lydekker $(1876,1877,1883)$ was discussing supra-generic relationships he cast aside most of the detailed osteological comparisons that he made between Merycopotamus, Sus and Hippopotamus which showed that in many features Merycopotamus differed fundamentally from Hippopotamus (Table 1) and instead his classificatory decisions were based almost exclusively on the form of the angle of the lower jaw. In 1883, Lydekker's classification shows Merycopotamidae in Selenodontia (Tetracuspidati) well separated from Hippopotamidae which is classed in the Bunodontia, yet in the text in the previous page (Lydekker, 1883, p. 145) he lamented that in the table "the relationship of Hippopotamus to Merycopotamus is not apparent" the former genus being placed nearer to Pachysimia (ie Cebochoeridae) which is closer to Hyotherium (questionably classified in Dicotylidae by Lydekker) and Acotherulum Gervais, 1850 (Acotherulidae) both of which are included in Bunodontia by Lydekker. There is thus a curious ambiguity in Lydekker's writings, alternatively linking Merycopotamus to, and distancing it from, Hippopotamus. This ambiguity is highlighted by the sentence (Lydekker, 1883, p. 166) "The intimate resemblance of the molars (of Merycopotamus) to those of the Anthracotheridae and Oreodontidae leaves, however, little doubt but that the true position of the genus is in immediate juxtaposition to those families: the form of the mandible indicates, on the other hand, a distant cousinship with the hippopotamus".

\section{Stehlin}

Stehlin (1899-1900) considered that the hippo lineage emerged from Eocene Suiformes on the basis of the morphology of the back of the skull and the milk dentition, which reflected that of Choeromorus (not the Middle Miocene Sansan material, but Eocene fossils that are today referred to the Cebochoeridae or at the beginning of the 20th Century to Choeromoridae). He considered that the hippo ancestor would have been of medium size, bunodont, with a distally open orbit, flat skull roof, normal zygomatic arch, moderately elongated extremities and four toes. He stressed that the difficulty with «Choeromorus» resided in insufficient knowledge of Eocene skulls, and the lack of useful Oligocene or Miocene forms, but proposed «possibly at the end of the Eocene, one of the Choeromoridae, nearly related to Acotherulum, found a refuge in the southern continent (ie Africa) where during the Oligocene and
Miocene periods it gradually farther differentiated in the direction of the Hippopotamidae» (translation in Forsyth Major, 1902). Recent support for a choeromorid ancestry of hippos has been published by Theodor \& Foss (2006).

\section{Andrews}

C. W. Andrews (1906) wrote a paper that unduly influenced subsequent research into hippo origins, despite his comments about hippo-anthracothere relationships being based on similarities between a single bone (the pelvis) of each group. Colbert (1935) for instance was greatly impressed with the paper and cited from it in extenso in support of his thesis that hippos descended from anthracotheres. In fact, Andrews (1906, p. 186) restricted his comments to the pelvis, which he noted was of similar construction in Ancodon Pomel, 1847, Brachyodus Depéret, 1895, and Hippopotamus. None of the other bones of Ancodon from the Fayum, Egypt, described by Andrews (1906) resemble in detail those of hippopotami. The few resemblances that there are, are due to the fact that both are suiform artiodactyls. The cranium and dentition of Ancodon gorringei Andrews, 1906 (later put into the genus Brachyodus) and Hippopotamus are entirely divergent as are most of the post-cranial bones (long and slender in Ancodon, short and robust in Hippopotamus).

\section{Joleaud: Depéret}

Joleaud (1920) proposed that the Indian hippo lineage descended from Aprotodon Forster Cooper, 1915, a genus from the Oligocene of Baluchistan, an idea reiterated by Depéret (1921). As it happens, Aprotodon is a rhinocerotid (McKenna \& Bell, 1997; Guérin, pers. comm.).

\section{Pearson}

Pearson $(1927,1929)$ compared the basicranium and otic region of a wide diversity of artiodactyls, making a significant contribution to the understanding of the relationships of the genera to each other. Unfortunately she failed to realise that what she described as a skull of Palaeochoerus from St-Gérand-le-Puy, was in fact a cranium of Hyotherium, a suid. This misattribution in no way detracts from her anatomical analysis of the specimen, but it does affect her conclusions regarding the relationship between «Palaeochoerus» and other artiodactyls. This misattribution has confused many subsequent workers (Boisserie et al., 2005a, 2005b) even though the correct identification was first published in 1974 by Ginsburg, and confirmed by Van der Made (1996, 1997). 
Pearson $(1927,1929)$ who carried out extremely detailed comparisons on many artiodactyls, considered that hippos were most likely descended from Cebochoerus Gervais, 1848 , although she noted several similarities between the skulls of peccaries and hippos. She was adamant that Merycopotamus was radically divergent from Hippopotamus, going to the extent of making a detailed study of the hinder part of the skull of the two genera. This study resulted in Merycopotamus being reclassed as an anthracothere. Where its basicranium and occiput differed from that of other anthracotheres (and in her opinion, it did not differ much) it was not in the direction of Hippopotamus. The cebochoerid hypothesis has taken on renewed interest (Theodor \& Foss, 2006) with the realisation that it and some close relatives possess deciduous dentitions which recall cetacean teeth.

\section{Dietrich}

Dietrich (1928) described the fossil Pleistocene hippopotami from Tanzania, and briefly discussed the origin of the family. He dismissed Joleaud's (1920) derivation of hippos from Aprotodon rather harshly «führt zu phantastischer Absurdität» explaining that the natural sequence of reduction of the incisors would be Hexa - Tetra $-D i$ - A-protodon, which is the opposite of the sequence proposed by Joleaud. Dietrich seems to have been unaware that Aprotodon is in fact a rhinocerotid. He appears to have agreed more or less with Stehlin's (1899-1900, 1908) views on hippo origins, and went on to propose that in its appearance, the ancestor of the hippos would have approximately resembled Tayassu Fischer de Waldheim, 1814, among the living suids (at the time New World peccaries were included in suids by some authors) but he did not venture to identify any possible ancestor.

\section{Matthew}

Matthew (1929b, 1934) wrote of hippo origins «Their derivation has been supposed to be from the anthracotheres, through Merycopotamus. This is quite certainly wrong. They are derived from the Suidae.... The smaller Pleistocene species ... are very suggestively like midTertiary Suidae in construction of molars and premolars. This is especially true of Hyopotamus minutus Blainville, 1847, from Cyprus and Crete collected by Miss Bate, which strongly reminds one of such primitive Suidae as Desmathyus Matthew, 1907, etc. out of the Upper Rosebud and Lower Sheep Creek of the Western United States». Given that Matthew (1934, chart) included in Suidae what we would today classify as palaeochoerids, tayassuids and suids (and possibly cebochoerids as well) and the fact that the Cypriot fossils are now attributed to the genus Hippopotamus, his conclusion is not far from the mark. It requires nuancing, but this is often the case with scientific hypotheses. Matthew (1929a) insisted that postcranial evidence is essential for the proper assessment of relationships between artiodactyl families, but his advice has generally been ignored by subsequent researchers, although two papers published recently (Theodor \& Foss, 2006; Geisler \& Uhen, 2006) included many post-cranial characters, which led to the conclusion that hippos were not the sister-group of anthracotheres.

\section{Geais}

Geais (1934) was able to reconstruct the skeleton of Elomeryx borbonicus (at the time attributed to Brachyodus) on the basis of numerous skeletal parts from St-Henri, near Marseille (Fig. 7). She documented the elongated limb elements of the species and the neck in which the atlas and axis resembled that of the wild boar [Sus scrofa (Linnaeus, 1758)] in general aspect and dimensions. Despite these differences from hippopotamids, she envisaged that the species, which was about the size of a pig, lived like hippos in troops in swampy areas, passing part of the day swimming in water and emerging onto the banks to eat and rest. Although Geais did not specifically address the origins of hippos, her reconstruction of the lifestyle and ecology of Elomeryx borbonicus helped to perpetuate the view that anthracotheres looked, moved and behaved like hippos, despite the differences in their body plan and limb bones.

\section{Colbert}

In his discussion on the origin of the Hippopotamidae, Colbert (1935) put great weight on the form of the mandible. As he described it «In Merycopotamus the symphysis is very heavy and broad, and the angle is produced ventrally in a manner extraordinarily similar to the ventrally produced angle in the Hippopotamidae». However, the symphyseal characters were already shown by Falconer \& Cautley (1836) not to be like those of hippos when they described it as being slender and narrow, so it is somewhat surprising to find Colbert (1935, p. 12) insisting so strongly on their resemblance to those of hippos. It is perhaps due to the fact that he compared only three genera, Merycopotamus, Hippopotamus and a highly derived suid, Conohyus. In this restricted comparison, Merycopotamus does indeed come out more similar to Hippopotamus, but since there are many other suoids that could (and should) have been included in the comparison, then Colbert's analysis [like Lydekker's (1876) one] is inadequate. What is even more surprising is that Colbert (1935, Fig. 3) like Falconer \& Cautley (1847) before him, incorrectly reconstructed the angle in the hippo mandible to look similar to that of Merycopotamus, introducing a rising notch in the ventral 
margin of the ramus immediately anterior to the descending angle, something that does not exist in Recent hippopotami. The rest of his analysis of the skull, dentition and post-cranial skeleton is likewise flawed, and in any case was extremely cursory. It ignored Lydekker's (1876) detailed descriptions and interpretations of the osteology of Merycopotamus, and it did not delve in any detail into Pearson's $(1927,1929)$ work on the basicranium and otic region of the skull, simply dealing with it in a paragraph of 8 lines. Because of the missing taxa and missing data for those taxa included in the study, it was inevitable that Colbert's (1935) study would be compromised. His conclusion that hippos descended from anthracotheres similar to Merycopotamus was thus not a convincing demonstration of hippopotamid phylogenetic relationships.

\section{Lavocat: Viret}

Lavocat (1955) did not enter into much detail about hippo origins, but he did write that «they evidently came from primitive bunodont ungulates». In contrast to Lavocat (1955), Viret (1961) arranged the Hippopotamidae among the Bunoselenodonta, but «without conviction» because, as he explained «It is clear that the method which consists of comparing the ends of branches, and which in addition, are the ends of branches with the same secondary adapation (in the case of Hippopotamus and Merycopotamus) cannot lead to a solution of the problem, the resemblances due to parallelism risking being taken for the expression of relationship» (my translation). The end of the sentence is particularly perspicaceous and prescient.

\section{Leakey: Thenius}

Leakey (1966) did not specifically discuss the question of hippopotamid origins, but reported the discovery of teeth at Fort Ternan, Kenya, with affinities to anthracotheres and hippopotamids, and this led to comments being published by Thenius (1969) and Gaziry (1987a) but both these authors were unaware that the Fort Ternan specimens are in fact the milk teeth of the proboscidean Afrochoerodon Pickford, 2001, and are thus irrelevant to the debate about relationshiops between hippos and anthracotheres. In his paper, Thenius (1969) rejected the close relationship between hippos and Merycopotamus proposed by Colbert (1935) and implied by Leakey (1966) and wrote that the latter genus could not represent the ancestor of hippos.

\section{Pickford}

Pickford (1983) erected the genus Kenyapotamus for two species of extremely primitive hippopotamids from
Maboko (16 Ma), Fort Ternan (13.7 Ma), Ngeringerowa (10-9 Ma), and Nakali (10-9.5 Ma), all sites in Kenya [the genus was subsequently discovered in the Samburu Hills, Kenya (Nakaya et al., 1987; Tsujikawa, 2005)] and at Beglia, Tunisia (Pickford, 1990, 2006). At the time of the study these were by far the earliest known hippopotamids, the previous oldest specimens being about 7 Ma. This prompted Pickford to re-examine the question of hippopotamid origins, partly because it was clear that Kenyapotamus Pickford, 1983, was not only older than Merycopotamus, the previous contendor for ancestry of hippos (Falconer \& Cautley, 1836, 1848; Colbert, 1935) but also because its dentition and talus were radically different from those of Merycopotamus. Examination of the literature and fossil material resulted in the view that hippos were closer to the Suoidea than to any other artiodactyls, as maintained by Pearson $(1927,1929)$ and Matthew (1929b) so Pickford (1983) proposed a descendence from what were known at the time as Old World Tayassuidae (not to be confused with New World Tayassuidae). He realised that hippos did not descend from New World Tayassuidae, counter to the hypothesis of Matthew (1929b) (see above) but proposed that they were derived from a different family of suoids (now known as Palaeochoeridae) that is known mainly from Europe.

It has been appreciated for at least 15 years that the so-called «Old World tayassuids» or as they were sometimes called «doliochoerines» are not closely related to New World Tayassuidae (Pickford \& Morales, 1989) and that they warranted full familial status (Pickford, 1993, Fig. 1, 2). Pending formal publication of this, Pickford (1993) followed Simpson's (1945) classification, as did Ginsburg (1974) Hellmund (1992) and Sudre (1995) but he was clear in his writings that doliochoeres were not particularly close to New World tayassuids, having separated from them during the basal Oligocene or earlier. Alas, application of the word «tayassuid» to the Old World doliochoeres has caused a great deal of confusion, with many authors failing to understand the implications of the qualifying prefix «Old World» in front of it (Randi et al., 1996; Lihoreau \& Boisserie, 2004; Boisserie et al., 2005a, 2005b). In retrospect it is evident that Pickford should at the outset have scrapped the word «tayassuid» when discussing doliochoeres, but because of the historical precedent, the word remained attached to the group until Van der Made's (1996, 1997) papers. The latter papers seem to have escaped the notice of many molecularists and palaeontologists.

It was not until detailed studies of Early Miocene suoids of Europe had been published (Ginsburg, 1974; Hellmund, 1992; Van der Made, 1996, 1997) that it was possible to resolve the systematic issue in a satisfactory way. Until these works were completed, there remained considerable doubt about the familial status of the genus Palaeochoerus and some of the other suoids from the Late Oligocene and Early Miocene. The formal recognition of the separate fa- 
milial status of the «Old World Tayassuidae» took place 22 years after Ginsburg's (1974) breakthrough, in papers published by Van der Made $(1996,1997)$ who resurrected Matthew's (1924) subfamily Palaeochoerinae (Matthew, 1929a) which has priority over Simpson's (1945) Doliochoerinae, but he raised it to family rank on account of the rather fundamental differences in cranial, dental and post-cranial morphology that these suoids have from New World Tayassuidae. He also excluded all the North American genera that Matthew listed in the subfamily.

Pickford (2007) erected the genus Palaeopotamus for hippopotamid material more primitive than Kenyapotamus. The type species is Palaeopotamus ternani (Pickford, 1983) from Fort Ternan (ca $13.7 \mathrm{Ma}$ ) a species which is also present at Maboko (ca $16 \mathrm{Ma}$ ) and Kipsaraman (ca 14.7 Ma). Among Artiodactyla, the teeth of P. ternani are morphologically most similar to those of Palaeochoerus typus (see Hellmund, 1992), but they are appreciably larger.

\section{Gaziry}

Gaziry $(1982,1987 b)$ proposed that hippopotamids and Merycopotamus both descended from Hyoboops Trouessart, 1904 (now known as Sivameryx Lydekker, 1883) but he noted that even if his suggestion were the case, the lineage terminating in Merycopotamus must have separated from that leading to hippos at the time that Hyoboops lived (ie Early Miocene or base of the Middle Miocene). He noted that the latter genus did not possess a downturned mandibular angle, and that therefore the morphological similarities between hippos and Merycopotamus must be due to parallelism, a point he reiterated in a companion paper (Gaziry, 1987a). He envisaged an Asiatic origin of Merycopotamus followed by migration to Africa where it is represented by two species Merycopotamus anisae (Black, 1972) and Merycopotamus petrocchii (Bonarelli, 1947) both of which are now classified in the genus Libycosaurus Bonarelli, 1947 (Pickford, 1991). He envisaged an entirely separate African origin for Hippopotamus. On the basis of the supposed morphological similarities and a supposed common ancestor, he proposed that hippos should be classified as a subfamily of Anthracotheriidae. Alternatively, he argued that if this relationship was not correct, then hippos must have descended from Dichobunidae, citing the analysis of Pilgrimella Dehm \& Oettningen-Spielberg, 1958, from the Eocene of Pakistan.

\section{Gentry \& Hooker}

Gentry \& Hooker (1988) analysed many artiodactyl taxa using a cladistic approach and concluded that the "'Anthracotheriidae' ... become paraphyletic by the nesting of Hippopotamidae within them" and that the "old classic primary division of artiodactyls into Bunodontia and Selenodontia is supported". These authors, unlike Kowalevsky $(1873,1874)$ thus support the inclusion of hippos within the Selenodontia.

\section{Van der Made}

Van der Made (1999) classified the Families Anthracotheriidae and Hippopotamidae in the Superfamily Hippopotamoidea, on the supposed basis that «numerous dental, cranial and postcranial characters, as well as the characters of the soft tissues argue against (Pickford's) model» (that anthracotheres and hippos belong to two separate superfamilies). However, Van der Made (1999) provided no details of the numerous characters, which makes his claim somewhat unsatisfactory, mainly because no soft tissues of anthracotheres are known, and because in anthracotheres and hippos there are manifest differences in cranial, dental and postcranial morphology.

\section{Boisserie, Lihoreau \& Brunet}

Because of the perceived refutation of the «peccary» hypothesis of hippo origins by molecularists, Lihoreau \& Boisserie (2004) and Boisserie et al. (2005a, 2005b) re-examined the question of hippo origins, and came to the conclusion that hippos were most closely related to bothriodontine anthracotheres. They envisaged that hippos descended from bothriodontine anthracotheres (ie the selenodont ones) with either Merycopotamus or the pair Merycopotamus plus Libycosaurus, as the sister group of hippos. They explicitly rejected the tayassuid and cebochoerid hypotheses of hippo origins. However, examination of their analyses reveals several areas of weakness, notably the problems of missing taxa, missing characters among the included taxa and insufficient background knowledge of the Suoidea. Their analyses focussed heavily on the cranium and dentition, the postcranial skeleton being represented only by the talus and the distal end of the metapodials.

Major difficulties emerge from the studies of Boisserie et al. (2005a, 2005b) as they themselves recognised. One is that hippo descendance from bothriodont anthracotheres would imply a «spectacular reversion» of dental morphology. In order to retain this possibility, the authors invoked the concept of «dental plasticity» which is itself somewhat contentious as a hypothesis. Secondly, their hypothesis ignores the many fundamental morphological differences that exist in almost all the bones and teeth of hippos and anthracotheres, even the supposed sister taxa Merycopotamus and Libycosaurus. As Lydekker (1876) Pearson $(1927,1929)$ and others have pointed out, the 
resemblances between hippos and anthracotheres are superficial, whereas detailed examination of their morphology reveals pervasive differences throughout the skeletal and dental systems.

A further difficulty with the research programme of Boisserie et al. (2005a, 2005b) and Boisserie \& Lihoreau (2006) is that they failed to test the palaeochoerid hypothesis (which used to be called the Old World Tayassuidae hypothesis). Admittedly the literature on suoids is somewhat confusing, but it has been known for two decades that the Old World Tayassuidae differed at the family level from the New World Tayssuidae (Pickford, 1993). Once sufficiently detailed studies of European late Oligocene and Early Miocene suoids had been done (Hellmund, 1992) it became clear that their relationships to Tayassuidae (sensu stricto - ie the American forms) was no longer as close as Pearson (1927) and Simpson (1945) thought, but for the time being they continued to be classified in the same family (Hellmund, 1992; Sudre, 1995). Eventually, Van der Made (1996, 1997) resurrected the name Palaeochoeridae (Matthew, 1924) for the European taxa.

Boisserie et al. (2005a, 2005b) did not refer to these developments, and furthermore, used a skull of Hyotherium (a suid) to score the characters for Palaeochoerus. The history of this particular skull and some postcranial remains from the same locality (St-Gérand-le-Puy) is confusing, because for over a century they were attributed to Palaeochoerus (see Kowalevsky, 1873, 1874; Pearson, 1927; Lavocat, 1955; Viret, 1961). However, Ginsburg (1974) realised that they belonged to the genus Hyotherium (see also Van der Made 1996, 1997). Transposing the Palaeochoerus data to Hyotherium in the papers of Boisserie et al. reduces the representation of Palaeochoeridae in their analyses to a single genus, Doliochoerus Filhol, 1882, for which over 22\% of the characters are missing. Examination of real specimens of Palaeochoerus (see Hellmund, 1992) reveals rather divergent scoring of characters, all of which show similarities to hippopotamids. Inclusion of Palaeochoerus and other Palaeochoeridae in the cladistic analysis will certainly result in radically different phylogenies from those proposed by Boisserie et al. (2005a, 2005b) and Boisserie \& Lihoreau (2006).

\section{Theodor \& Foss: Geisler \& Uhen}

Recently, Theodor \& Foss (2006) have noted dental similarities between cebochoerids and whales, which indicates that Stehlin's (1899-1900) and Pearson's (1927, 1929) hypotheses need re-examining in detail, as suggested by Pickford (1989). Theodor \& Foss (2006) and Geisler \& Uhen (2006) concluded that anthracotheres are not closely related to hippopotamids.

\section{DETAILED COMMENTARY ON THE RECENT HYPOTHESIS THAT ANTHRACOTHERIIDAE IS THE SISTER GROUP OF HIPPOPOTAMIDAE}

\section{Systematic problems}

Lihoreau \& Boisserie (2004) and Boisserie et al. (2005a, 2005b) approached the question of hippopotamid origins as a choice between two alternative hypotheses: Anthracotheriidae or Tayassuidae (the cebochoerid hypothesis was mentioned in the latter two papers but was not retained). This summary of the problem is incomplete, because it omits Palaeochoeridae (until recently called Old World Tayassuidae) previously the strongest contendor for ancestral status (Pickford, 1983, 1993; Pickford \& Morales, 1989). In addition to the classificatory and nomenclatural problems, there are numerous difficulties with the character analyses presented by Boisserie et al. (2005a, 2005b).

\section{Taxon choice}

The problem of which taxa to include in any phylogenetic analysis is ever present. Boisserie et al. (2005a) included 32 taxa comprised of three extant peccaries, two fossil peccaries, a single palaeochoerid (listed as a tayassuid), four suids, six hippopotamids, eight anthracotheres, two archaeocetes, a cebochoerid, four ruminants and the genera Archaeotherium Leidy, 1850, and Diacodexis Cope, 1882. Palaeochoeridae did not feature as such in their analysis, which is regrettable since it is the group that Pickford (1983) considered to be the source of the hippopotamids. There are at least 7 genera of Palaeochoeridae known, of which two are represented by parts of the post-cranial skeleton. In contrast Theodor \& Foss (2006) included 51 taxa in their analysis and Geisler \& Uhen (2006) 73 taxa, many of which are not the same as those analysed by Boisserie et al. (2005a) only 14 taxa being common to the Boisserie et al. (2005a) study and one or both of the other two teams.

\section{Character choice}

Lydekker (1876) already showed that the post-cranial skeleton of Merycopotamus was markedly divergent from that of Hippopotamus. In the former the neck, basipodes and metapodials are elongated, whereas in the latter they are short. Most articulations and neighbouring osseous anatomy of the stylopodes and zeugopodes of Merycopotamus differ in morphology from those of Hippopotamus indicating divergent locomotor repertoires. Echoing the publications of Lydekker (1876) and Kowalevsky (1873, 
1874), Matthew (1929a) wrote that post-cranial evidence is essential for the proper assessment of relationships between artiodactyl families. Omission of most of the postcranial skeleton compromises the analyses of Boisserie et al. (2005a, 2005b) as shown recently by Theodor \& Foss (2006) and Geisler \& Uhen (2006).

Because of this, perhaps the most questionable aspect of the Boisserie et al. (2005a, 2005b) studies is the choice of characters used in the analyses. Only 8 out of 80 characters analysed by this team represent post-cranial features, confined to the talus (4 characters), the navicular and cuboid (1 character), the distal end of the metapodial (1 character), and the manual digits (2 characters). The remaining 72 characters were cranial (42 characters), mandibular (5 characters), and dental (25 characters). In their second paper dealing specifically with hippo origins, Boisserie et al. (2005b) included only two postcranial characters (astragalus and lateral digits) among a total of 37 characters. In the same paper 21 characters were scored for cranial morphology, 4 for the mandible and 10 for dental morphology.

\section{Missing data}

Missing data is a fundamental problem in phylogenetic analysis (Gatesy \& O'Leary, 2001) and omission of taxa or of features from most of the skeleton renders hypotheses of relationship open to modification, often quite radically.

Among the anthracotheres analysed by Boisserie et al. (2005a) there were relatively few missing characters (Table 3) whereas in the only palaeochoerid in the analysis almost a quarter of the characters (22.5\%) could not be scored.

\section{Scoring of characters}

Among the characters that could be discerned for $\mathrm{Pal}$ aeochoerus some were scored incorrectly. For example, character 8 in Boisserie et al. (2005a) (position of posterior nasal spine) is described as being in line with or anterior to the rear end of $\mathrm{M} 3 /$, yet in Palaeochoerus typus it is well behind the M3/ (Hellmund, 1992, Pl. 2, Fig. 1). Boisserie et al. (2005a, 2005b) did not score the position of the infra-orbital foramen (character 10) but it is clear from Hellmund (1992, Pl. 1, Fig. C) that it is in an anterior position above the $\mathrm{P} 3 /$ and should be scored as (0). Character 42 (mandibular symphysis fusion) should have been scored as (0) rather than missing. Character (52) (canine dimorphism) should have been scored (1) instead of missing (Hellmund 1992, Pl. 8). Character 58 (lower canine section) in Palaeochoerus is «D-shaped» (Hellmund 1992, Pl. 8) and it should therefore be scored as (1) rather than missing. In my opinion, character 60 (wrinkled or smooth enamel) in Palaeochoerus should have been scored as (0) instead of (1). Character 61 (root of P1/) is clearly doubled in Palaeochoerus (Hellmund, 1992, Pl. 1). Character 62 (form of talon of P3/, should have been scored (0) (Hellmund, 1992, Pl. 1). The P4/ of Palaeochoerus has two main cusps and a small posterior buccal one that is detached from the main cusp. The scoring categories defined by Boisserie et al. does not cater for this morphology of the P4/, but in Palaeochoerus and other palaeochoerids such as Schizochoerus and Choeromorus, it is closer to but not identical to their category (0) than to (1) or (2). Boisserie et al. (2005a, 2005b) scored it as (1) which I consider to be misleading. Character 65 (position of paraconule) was scored as being absent (0) whereas it is present, even if reduced in dimensions, and thus should

\begin{tabular}{|c|c|c|c|c|}
\hline Taxon & $\begin{array}{c}\text { Missing characters } \\
(\text { Total when } \\
\text { complete }=\mathbf{8 0})\end{array}$ & $\begin{array}{c}\text { Cranial } \\
\text { (Total when complete } \\
=47 \text { ) }\end{array}$ & $\begin{array}{c}\text { Dental } \\
(\text { Total when } \\
\text { complete }=25)\end{array}$ & $\begin{array}{c}\text { Post-cranial } \\
\text { (Total when } \\
\text { complete = 8) }\end{array}$ \\
\hline Doliochoerus & 18 & 15 & 0 & 3 \\
\hline Xenohyus & 50 & 42 & 1 & 8 \\
\hline Kenyapotamus & 59 & 46 & 8 & 5 \\
\hline Palaeochoerus* & 22 & 9 & 5 & 8 \\
\hline Libycosaurus & 2 & 2 & 0 & 0 \\
\hline Merycopotamus & 1 & 1 & 0 & 0 \\
\hline Anthracokeryx & 7 & 3 & 0 & 4 \\
\hline Microbunodon & 2 & 1 & 0 & 1 \\
\hline Elomeryx & 5 & 2 & 0 & 3 \\
\hline Brachyodus & 5 & 3 & 2 & 0 \\
\hline
\end{tabular}

* All the characters scored for Palaeochoerus refer in fact to the suid Hyotherium.

Table 3. Missing characters in analyses of Suiformes by Boisserie et al. (2005a). 
have been scored as (1). Finally as concerns the dentition, the pentacone of M3/ is absent in Palaeochoerus, not present as scored by Boisserie et al. (2005a). Boisserie et al. (2005a, 2005b) did not score any of the postcranial characters for Palaeochoerus.

These contradictions and omissions led me to search for the reason why my assessment of the morphology of Palaeochoerus is so divergent from that of Boisserie et al. (2005a, 2005b). It transpires that they based their determinations on cranial remains published by Pearson (1927) unaware that the said material belongs to the suid Hyotherium (see Ginsburg, 1974; Van der Made, 1996).

The only Palaeochoeridae included in the analysis by Boisserie et al. (2005a, 2005b) was Doliochoerus quercyi Filhol, 1882, some of the characters of which need nuancing. For example, the short gap of $3 \mathrm{~mm}$ between the lower canine and the anterior premolar in Doliochoerus is not the same order of magnitude as the diastema in Tayassuidae (Dechaseaux, 1959) and in my opinion should be scored differently from the simple «absent» or «present» categories used by Boisserie et al. (2005a). Four other characters (wrinkling of the cheek tooth enamel, the number of cusps in $\mathrm{P} 4 /$, the quantity of roots in $\mathrm{P} 4 /$ and the presence or absence of a paraconule in the upper molars) need to be reassessed. Apart from that, the only postcranial bone of Doliochoerus analysed was the talus (four characters scored).

\section{Cranial evidence}

Boisserie et al. (2005a, character 18; 2005b, character 8) like Lydekker $(1876,1877,1883)$ before them, were impressed by the superficial similarities between parts of the skulls of some anthracotheres, such as Libycosaurus and Merycopotamus on the one hand and those of Hippopotamus on the other. In particular they focussed on the elevation of the upper margin of the orbits above the dorsal profile of the skull, and concluded that this represented shared derived morphology denoting a close phylogenetic relationship between the two families. Boisserie (2005, Fig. 8 ) however, wrote that the same character was derived independently in three different lineages of hippopotamines due to convergence. There is therefore a contradiction between conclusions reached in successive publications by Boisserie (2005) and Boisserie et al. (2005a, 2005b). For elevated orbits to be convergently derived in distinct lineages of hippos, then the ancestors must have had low orbits, and this is indeed the case, both Archaeopotamus Boisserie, 2005, and Saotherium Boisserie, 2005, among the fossils and Choeropsis Leidy, 1853, among the extant hippopotamids having non-projecting orbits. In this case the fact that some hippos and some anthracotheres have elevated orbits, means that this condition must be due to convergence, and is not due to shared ancestry between anthracotheres and hippos. Apart from this, the orbits in Libycosaurus are not particularly strongly elevated, and their form is different from that of hippos.

Lihoreau (2003, Fig. I.57B, I.69B) recorded an unusual orbital morphology in Libycosaurus, with the inferior post-orbital process issuing from the squamosal. This inhabitual construction is reported to occur in two species from Chad, Libycosaurus petrocchii (Bonarelli, 1947) and Libycosaurus sp. nov. In contrast, in hippos this process rises from the jugal and the squamosal does not participate in the construction of the orbital margin (Frechkop, 1955). If correctly reported, then the squamosal morphology of Libycosaurus distances it from all other artiodactyls.

Boisserie et al. (2005a, 2005b) proposed that the anthracothere pair Libycosaurus and Merycopotamus formed a clade which was the sister-group of hippos. The supposed close relationship between Merycopotamus and hippos harks back to the work of Colbert (1935) and his predecessors (Falconer \& Cautley, 1848; Lydekker, 1876, $1877,1883)$ who saw in Merycopotamus a close relationship to hippos. However, in 1929, Pearson had already shown that the basicrania of Merycopotamus and Hippopotamus were not similar to each other, particularly in the form and position of the glenoid and surrounding structures, nor in the occipital region. She pointed out when discussing the basicranium and occiput «The hinder region of the skull of Merycopotamus shows only slight differences from that of all anthracotheres, and these differences are not in the direction of Hippopotamus». This is a fairly clear statement that distances the hippos from the anthracotheres, including Merycopotamus. As far as I can judge from the morphology of the basicranium and occiput of Libycosaurus anisae (Black, 1972) (Pickford, 2006) it is also a typical anthracothere, and does not approach the morphology of hippos. This is confirmed by examination of the dorsal aspect of the skulls. In anthracotheres the braincase is elongated and endowed with a long sagittal crest which curves ventrally as it approaches the occipital, whereas in hippos the braincase is shortened and the short sagittal crest bends upwards as it approaches the occiput (Fig. 14). The latter morphology is functionally related to the ritualised contests that hippos practice, in which they raise the head vertically, at the same time that they open their mouths wide to expose the incisors, canines and pink tissues within the mouth. It is unlikely that Libycosaurus or any other anthracothere could extend their heads so far backwards over the neck as do hippos.

The sagittal crest in Libycosaurus is antero-posteriorly elongated (Pickford, 2006) whereas in Choeropsis it is short and in Hippopotamus remarkably so. Palaeochoeridae such as Palaeochoerus from St-Gerand-le-Puy and Choeromorus from Sansan that could be scored for this morphology are similar to Hippopotamus. Sagittal crest morphology thus supports the palaeochoerid hypothesis at the expense of the anthracothere one. 


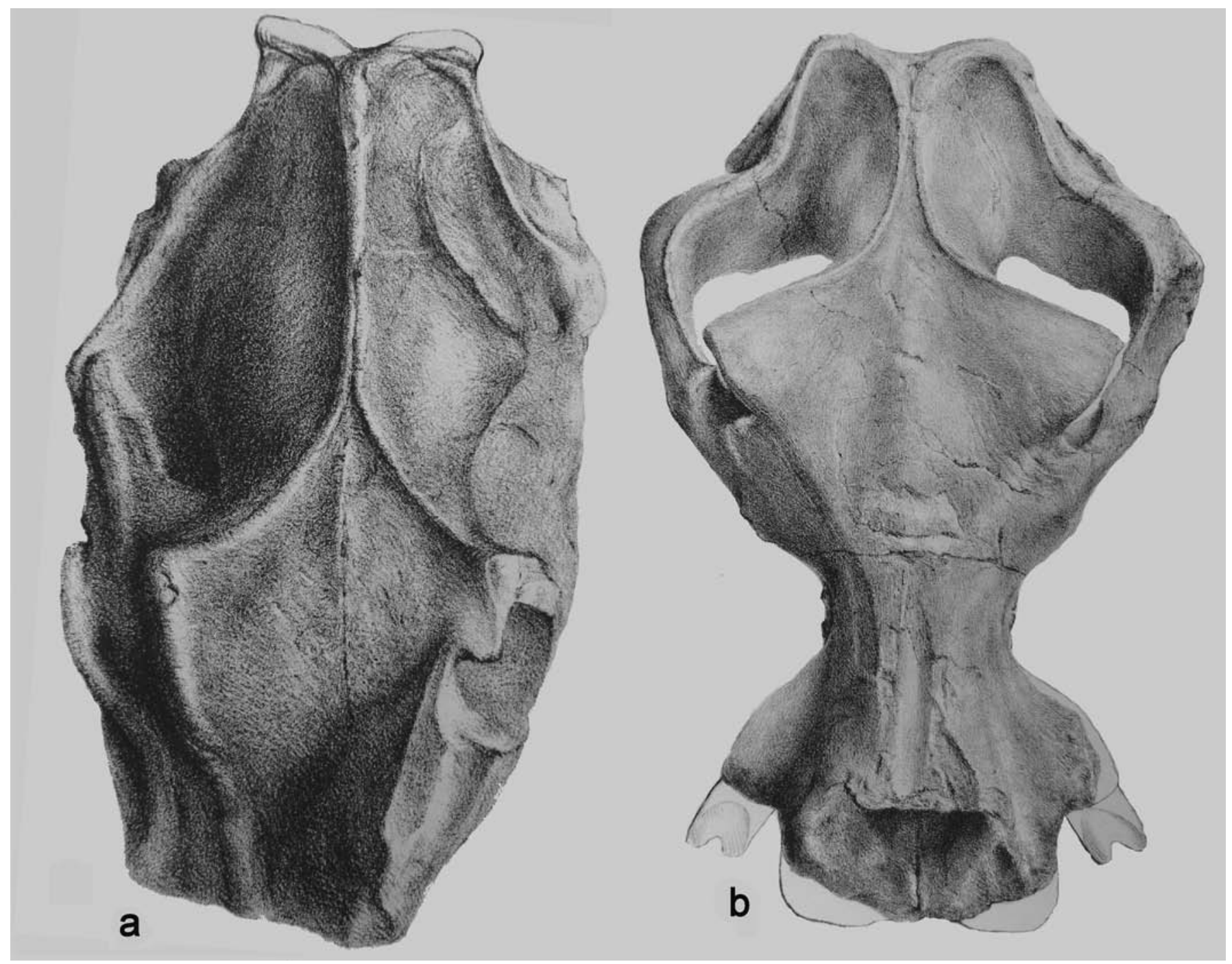

Figure 14. Comparison of sagittal crest morphology in (a) Merycopotamus Falconer \& Cautley, 1848, and (b) Hippopotamus Linnaeus, 1758 (modified from Falconer \& Cautley, 1848). Anthracotheres are klinorhynch and have elongated crests, whereas hippos are airorhynch and as a result have shortened crests (not to scale).

Linked to the orientation of the sagittal crest is the orientation of the basicranium, both being related to the way that the splanchnocranium is hafted onto the neurocranium. Hippos, like suids and palaeochoerids, are airorhynch, with the splanchnocranium rotated dorsally with respect to the brain case, and as a result the basicranium is entirely above the plane of the molars. In anthracotheres in general and bothriodonts such as Merycopotamus and Libycosaurus in particular, the opposite is the case, with the splanchnocranium rotated ventrally with respect to the brain case, with the result that the basicranium is beneath the occlusal plane of the molars. Anthracotheres are therefore klinorhynch.

Because hippos are airorhynch and anthracotheres are not, the shape of the squamosal is quite different in the two groups (Fig. 15). In hippos the zygomatic process of the squamosal is bent dorsally rather sharply, imparting a
V-shaped outline to the upper profile of the bone in lateral view (Frechkop, 1955) whereas in anthracotheres the arch curves gently upwards towards the distal base of the orbit (Lihoreau, 2003) and is thus of an open C-shape.

The splanchnocranium of Libycosaurus is marked by two structures that do not occur in hippopotamids, the presence of a facial tuberosity separated from the facial crest, and the presence of an extensive canine fossa (Lihoreau, 2003, Fig. I.57B). Furthermore, the infraorbital foramen in Libycosaurus is located far anterior from the facial crest of the jugal, with the facial tuberosity interposed between the two elements, whereas in hippos it is immediately in front of the anterior termination of the facial crest. In addition, the facial crest in Libycosaurus rises steeply (ca $45^{\circ}$ to the tooth row) from distal to proximal, whereas in hippos it is at a shallower angle (ca $30^{\circ}$ to the tooth row) (Fig. 15). 

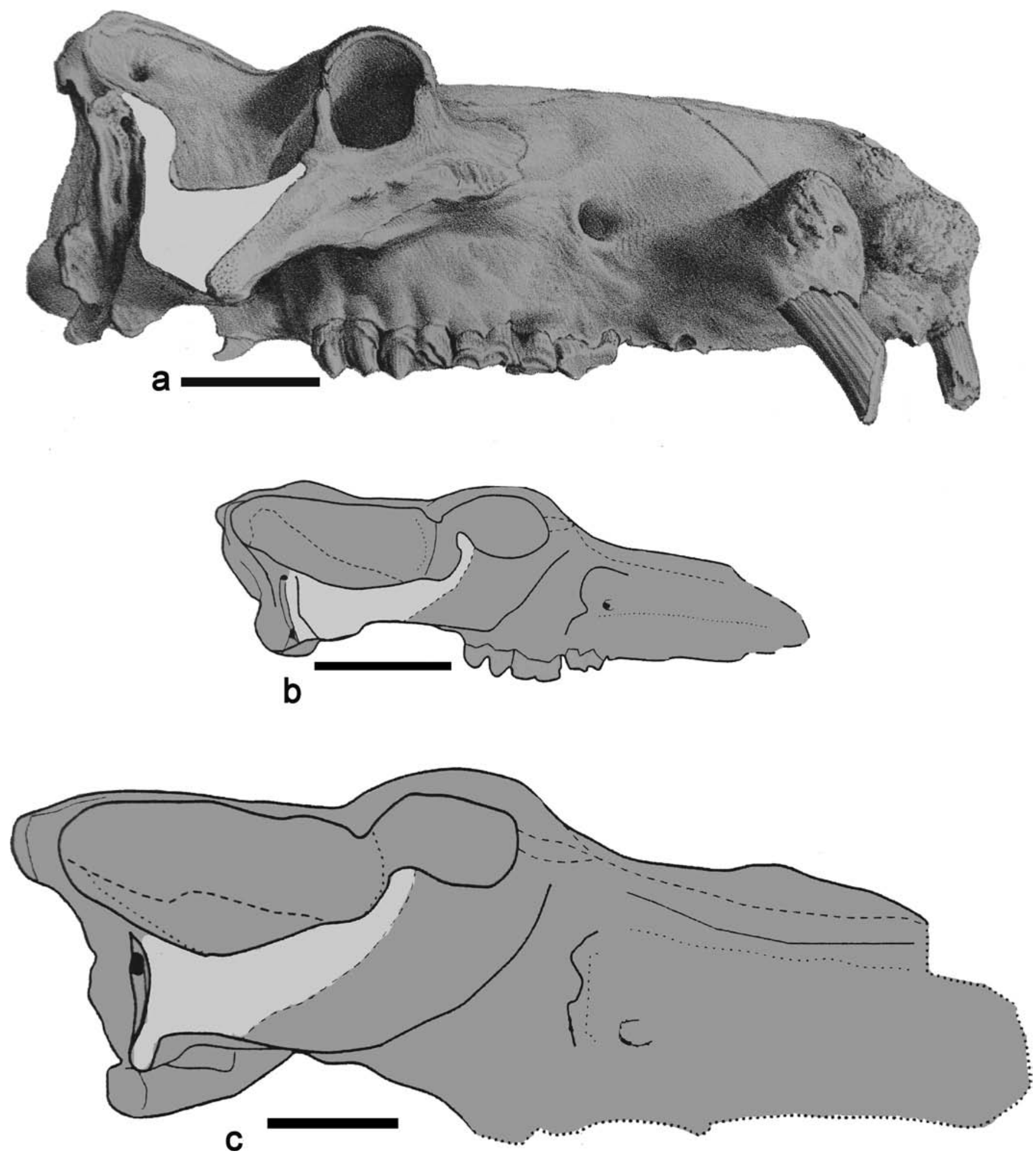

Figure 15. Squamosal and facial morphology in (a) Hippopotamus Linnaeus, 1758 (from Blainville, 1847) and (b, c) two species of Libycosaurus Bonarelli, 1947 (modified from Lihoreau, 2003). The squamosal morphology (light grey) reported in Libycosaurus is unique among artiodactyls, this bone participating in the orbital margin. In hippos the squamosal is deeply recurved (reflecting the airorhynch hafting of the splanchnocranium onto the neurocranium) whereas in anthracotheres its shape is not markedly different from that of other artiodactyls. The morphology of the maxillary root of the zygomatic arch and the absence of a facial tubercle distance the hippo from Libycosaurus (scale for Libycosaurus: $10 \mathrm{~cm}$ ). 
In palatal view, Libycosaurus has a deep channel in the palate extending from the anterior premolar where it is shallow, towards the premaxillae deepening considerably as it goes (Pickford, 1991). This channel is bordered each side by sharp, curved crests of bone, the alveolar ridges, that extend between the anterior premolar and the disto-medial base of the canine jugum (Fig. 16). Proximal to the anterior cheek tooth, the ridges converge towards each other before diverging towards the canine bases. In hippos in contrast, the palatal depression (character 6 in Boisserie et al., 2005a) is considerably shallower, does not deepen anteriorly to any great extent and is not bordered by sharp, incurved alveolar marginal crests (Fig. 16). These depressions are therefore not homologous, and they should not be scored in the same way. Indeed the morphology of this part of the snout in hippos and Libycosaurus is so divergent that it distances the two from each other, rather than approaching them together as suggested by Boisserie \& Lihoreau (2006).

In artiodactyls in general the palatine foramen is located opposite the molars at the contact of the palatine bone with the maxilla. The greater palatine artery and the palatine nerve emerge from this foramen (Sisson \& Grossman, 1953). In hippos and peccaries the bony opening for this ar- tery and nerve is considerably further forwards, the palatine canal being «buried» within the maxilla, but with abundant small connections to the surface along its route (Pickford, 1983). According to Boisserie \& Lihoreau (2006) this is clearly a derived morphology among the artiodactyls, which agrees with Pickford's (1983) assessment of the character. However, according to Boisserie \& Lihoreau (2006) only Libycosaurus among the anthracotheres possesses such an anterior opening (described as an intercanine palatine groove, not to be confused with the intercanine palatal depression) but in the matrix of characters a few other anthracotheres are scored as possessing the same morphology. Even though the morphology is clearly derived within an artiodactyl context the question is, is its presence in hippos and Libycosaurus a synapomorphy or not ? The major differences in the morphology of the palate between the canines and premolars of hippos and Libycosaurus suggests that it is most likely a convergence, and is not homologous.

In basicranial view, the paroccipital process of the exoccipital in hippos is short and is directed obliquely postero-ventrally. The medial edge is in line with the lateral edge of the occipital condyles and in posterior view the two processes are almost parallel to each other. In Libyco-
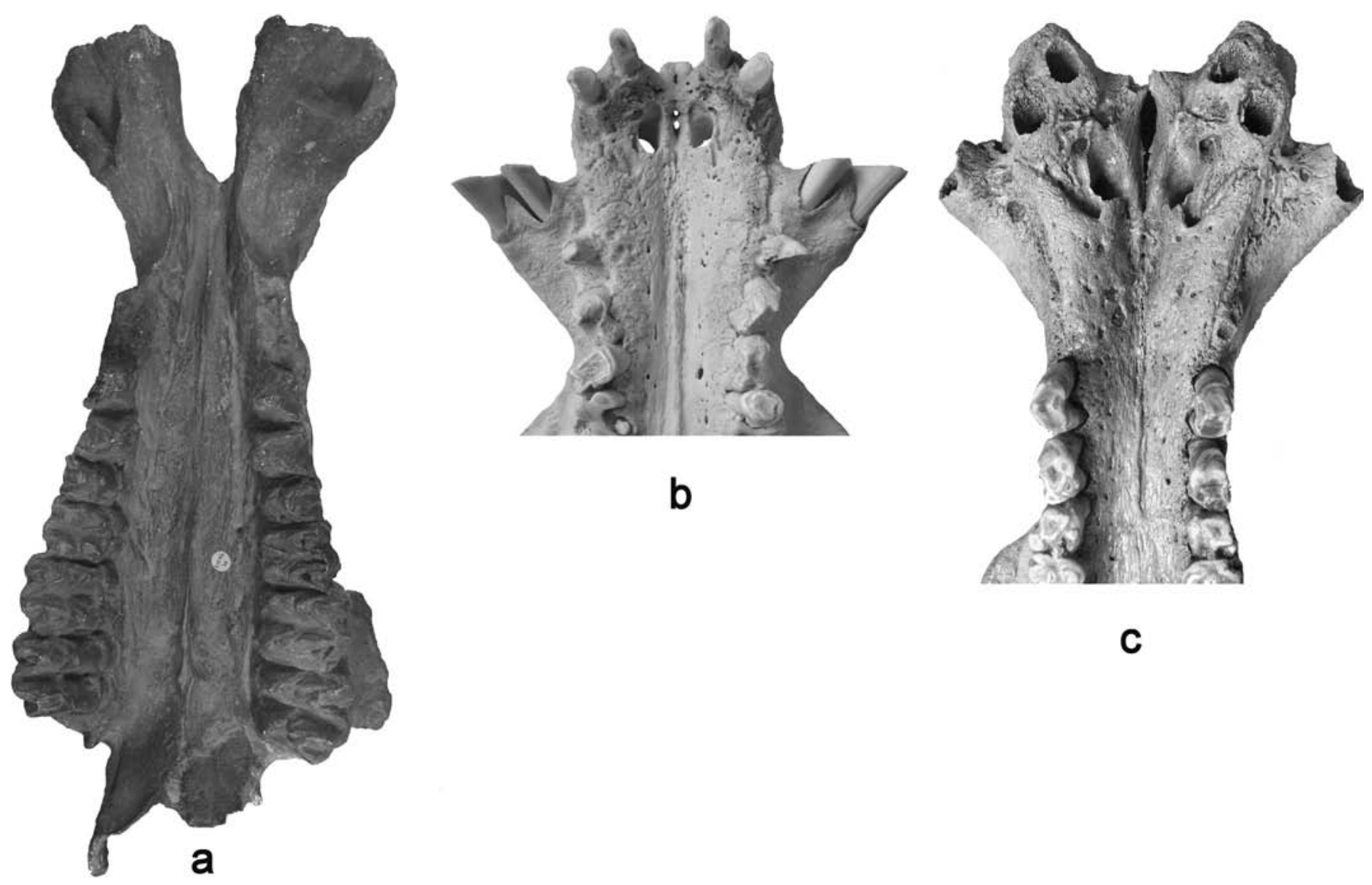

Figure 16. Morphology of the anterior portion of the palate in (a) Libycosaurus Bonarelli, 1947, (b) Choeropsis Leidy, 1853, and (c) Hippopotamus Linnaeus, 1758. In the anthracothere the morphology of the palate between the canines and anterior premolars is completely different from the pattern expressed in hippos (not to scale). 
saurus in contrast, the paroccipital processes (mastoid apophysis of the exoccipital in Lihoreau, 2003) are longer and terminate lateral to the occipital condyles, and they appear to diverge from each other at a marked angle (Lihoreau, 2003, Fig. I.58B, C).

The glenoid fossa in hippos is interrupted laterally by the lateral glenoid tuberosity, a low, roughened swelling of bone that extends about $1 / 3$ of the latero-medial extent of the glenoid surface, separating the articular surface from the zygomatic process. As a result, the glenoid surface descends slightly ventrally towards its lateral extremity. In Libycosaurus, in contrast, there is no tuberosity, but a smooth transition from the articular surface into the zygomatic process, and the lateral extremity curves gently dorsally. Furthermore, in hippos, the retro-glenoid process is restricted to the inner $1 / 3$ of the extent of the glenoid surface and it faces somewhat antero-laterally, being interposed between the glenoid articulation and the posterior part of the tympanic bulla. In Libycosaurus, the retro-glenoid process is appreciably broader medio-laterally, extending over more than half the extent of the glenoid surface, and it faces more anteriorly. It is more laterally positioned compared with hippopotamids, its medial root being lateral to the tympanic bulla, whereas in hippos it overlaps about $1 / 3$ of the bulla. Another point that needs to be made is the extremely posterior position of the glenoid articulation in hippos. In lateral view, the retro-glenoid process terminates behind much of the nuchal plane, whereas in anthracotheres it is positioned further anteriorly. In Choeropsis it is slightly further forwards than in Hippopotamus, but not as much as in anthracotheres. The differences between the basicrania of Merycopotamus and Hippopotamus were dealt with in detail by Pearson (1929) (Fig. 17).

In anthracotheres the tympanohyal pit is located anterior from the stylomastoid foramen, within the same depression between the tympanic bulla and the post-tympanic process of the squamosal. In hippos in contrast, the tympanohyal pit is separated from the stylomastoid foramen and is lateral and slightly posterior from it.

\section{Mandibular evidence}

Boisserie et al. (2005b) state that Pickford (1983) made two errors concerning mandibular fusion in anthracotheres and hippos. What the latter palaeontologist wrote was that
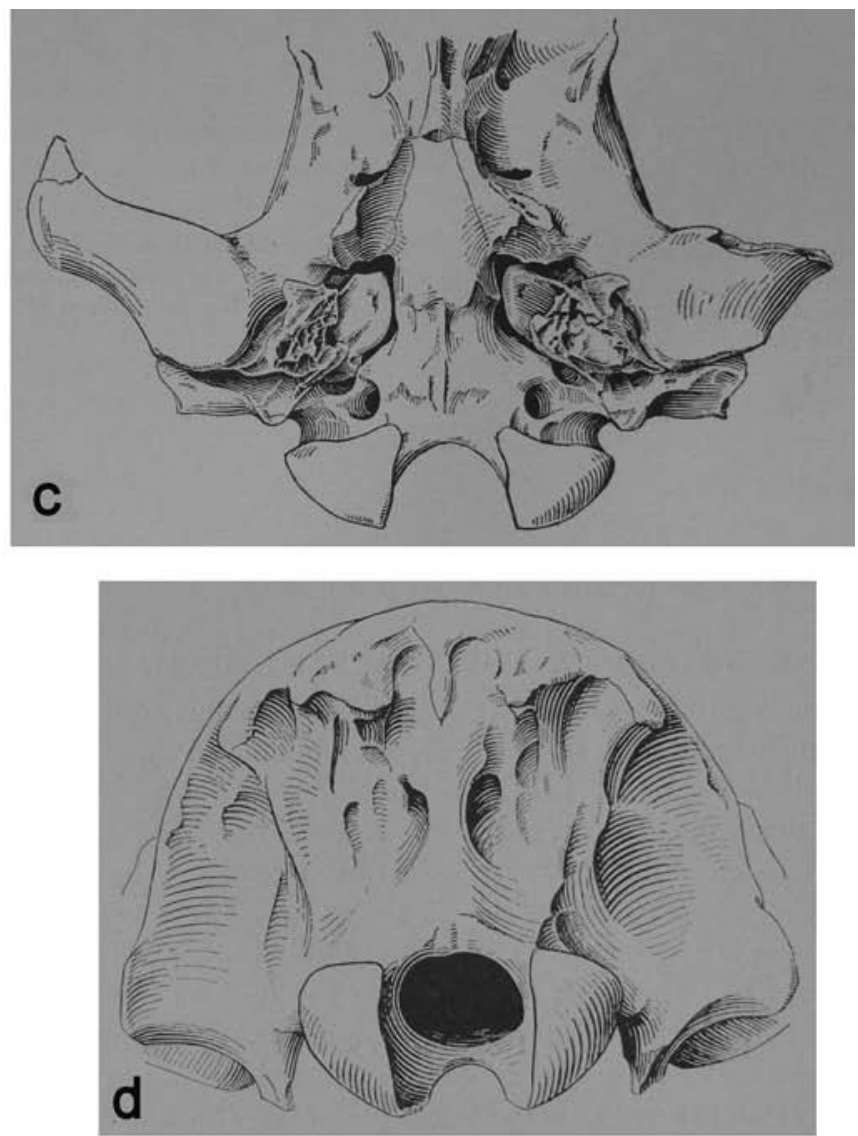

Figure 17. Morphology of the glenoid surface and occiput in (a, b) Merycopotamus Falconer \& Cautley, 1848, and (c, d) Hippopotamus Linnaeus, 1758 (modified from Pearson, 1929) (not to scale). 
hippo and palaeochoerid mandibles are fused soon after birth, whereas in most anthracotheres they usually remain unfused even in senile individuals. In Libycosaurus anisae the lower jaws of individuals with deeply worn third molars show no signs of symphyseal fusion in contrast to young hippo mandibles still containing the deciduous dentition, where the two halves of the jaw are difficult to separate from each other (Weston, 2003) just as they are in suids and palaeochoerids. There seems to be a problem with comprehension of the word «fused», arising in part from the literature. What Laws (1968) reported was that hippo mandibles remain unfused (or «open») until about 10-13 years of age. This has sometimes erroneously been taken to mean that the two halves of the jaw are separated from each other until this age, which appears to be the interpretation that Boisserie et al. have adopted. However, what Laws (1968) wrote was that fusion is not completed until 10-13 years of age, his criterion being that the two halves of the jaw can be moved with respect to each other until that age (scored by him as «open») after which they generally cannot (scored by him as «closed»). As it happens, hippo mandibles show progressive fusion of the symphysis, as in all mammals in which there is fusion between two bones or parts of bones. What differentiates hippos from Libycosaurus is that in the former the separation of the two halves of the mandible becomes difficult or impossible 3-4 years after birth or even earlier, whereas in the latter, the mandibles remain easily separable, even in senile individuals. Lihoreau (2003) report that the symphysis of Libycosaurus petrocchii from Chad is unfused, whereas that of Libycosaurus sp. nov. of Lihoreau (2003) is fused. This is interesting, because in the larger sample from Beglia, Tunisia, none of the Libycosaurus petrocchii mandibles is fused (Libycosaurus anisae in Pickford, 2006, submitted) in which case symphyseal fusion in the genus Libycosaurus developed after about 10 Ma. Except for one aged individual in the Natural History Museum, London, and another at Harvard University in America (Lihoreau, 2003) the mandibular symphysis of Merycopotamus, like that of Libycosaurus, is generally not fused, even in adult individuals. It is difficult to escape the conclusion that life history (in this case, growth) variables in hippos and anthracotheres, such as fusion of the symphysis, differed radically.

In hippopotamids, the descending plate of the mandibular angle flares outwards at a marked angle. This morphology allows the jaw to be opened extremely widely, the angle of the jaw not interfering with the neck when the jaw is wide open, as for example in the open-jawed ritual display that typifies hippopotamid social interactions. The descending plate in the mandible of Merycopotamus in contrast, does not diverge to any great extent, if anything they converge slightly ventrally, as in pigs and other anthracotheres. Under these circumstances, Merycopotamus would not have been able to open its jaws nearly as widely as hippos do, from which I conclude that the ritual display system in this genus (if it had any) would have been quite different from that of hippos.

\section{Dental evidence}

Boisserie et al. (2005a, 2005b) illustrated differences between molar morphology of the New World peccary, Tayassu, on the one hand and those of hippos and Libycosaurus, among other Suiformes, on the other. The demonstration that Tayassu has molars that are morphologically divergent from those of hippos does not refute the palaeochoerid hypothesis (Pickford, 1989) although it does weaken the tayassuid one.

The lower incisors of Libycosaurus were depicted by Boisserie et al. (2005a) as having prolonged to permanent growth, a description that was used to support the inference of a close relationship between this genus and hippos. Hippo lower incisors are hypselorhyzic, the crown rapidly disappearing with wear, leaving an elongated cylindrical root that continues to erupt throughout life (the pulp canal at the root apex remains open throughout life). Lower incisors of Libycosaurus petrocchii in contrast are of the usual mammalian kind, with a crown that erupts to gingival level, after which the tooth stops erupting (Fig. 18). As in many other mam-

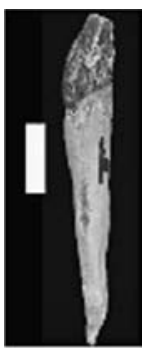

a1

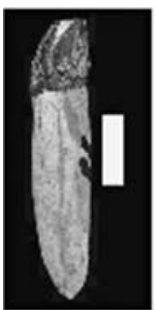

b1

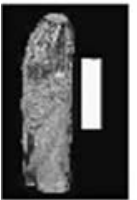

c1

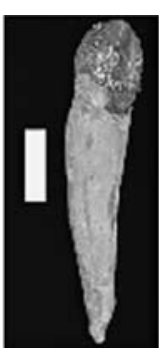

a2

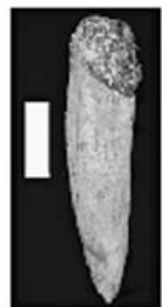

b2

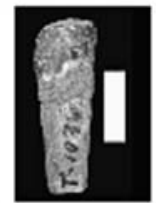

c2

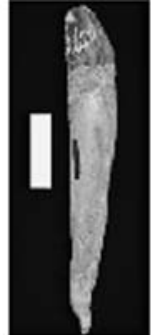

a3

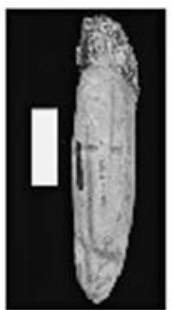

b3

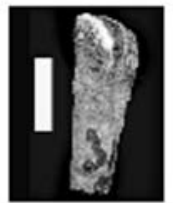

c3

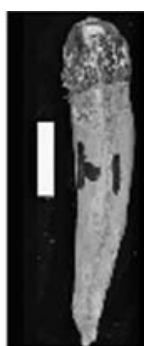

a4

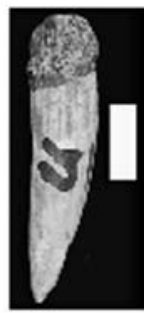

b4

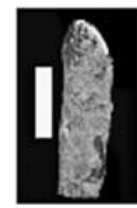

c4
Figure 18. Lower incisors of Libycosaurus petrocchii Bonarelli, 1947 [L. anisae (Black, 1972) in Pickford, 2006] (scale: $10 \mathrm{~mm}$ ). 
mals root growth continues until maturity when the apex of the root closes off (Pickford, 2006, in press).

The upper canines of Libycosaurus petrocchii were described by Boisserie et al. (2005a, character 55) as being vertically oriented. My examination of the species (Libycosaurus anisae in Pickford, 2006) reveals that the canine root is almost horizontal in the maxilla, its apex lying slightly above palatal level and lateral to the roots of the premolars, the apex lying beside the roots of P3/, and the crown is procumbent, although it does develop a vertical wear facet by abrasion against the lower canine. The orientation of the canine in Libycosaurus is thus radically different from that of hippos in which the internal apex of the canine (which incidentally has no root: ie is hypselodont) teminates well above palatal level.

The canines of Libycosaurus were described as evergrowing by Boisserie et al. (2005b) as in hippos. However, the canines of Libycosaurus petrocchii from Beglia, Tunisia (hitherto known as Libycosaurus anisae) are not permanently growing, neither is their growth prolonged (Fig. 19, 20). Pickford (2006, in press) showed that upper and lower canines in Libycosaurus petrocchii are normal mammalian canines in which the crown is clearly differentiated from the root by a cervix, and that the root of the canine is closed once maturity is reached. The crowns of these teeth erupt to gingival level, and then stop erupting, a major difference from hippo canines, which are hypselodont (arhyzic) and in which growth and eruption continue throughout life.

Character 58 in Boisserie et al. (2005a) concerns the lower canine section. Libycosaurus petrocchii is scored as having a triangular or 'D-shaped' section, which is surprising because material of this species from Tunisia has an ovoid section with a sharp distal crest (Pickford, 2006). The same acute distal crest is observed in the genus Merycopotamus.

Boisserie et al. (2005b) described the transverse sectional shape of the canines of most Bothriodontinae as being not very different from that of hippopotamids. However, the lower canines of Libycosaurus petrocchii are markedly divergent from the 'kidney-shaped' (or 'D-shaped) section that typifies hippo lower canines (Fig. 13). Pickford (2006) described the canines of Libycosaurus petrocchii (at the time identified as L. anisae) in detail and showed that the crown is canted on the root at an angle of about $30^{\circ}$ such that in anterior view the two crowns form a dihedral angle of $60^{\circ}$ with respect to the roots which are almost parallel to each other, very different from the almost vertically oriented lower canines of hippos as seen from the front in which there is no sign of canting of the tooth. Furthermore, in hippos, the lower canine is composed of two parts (buc-
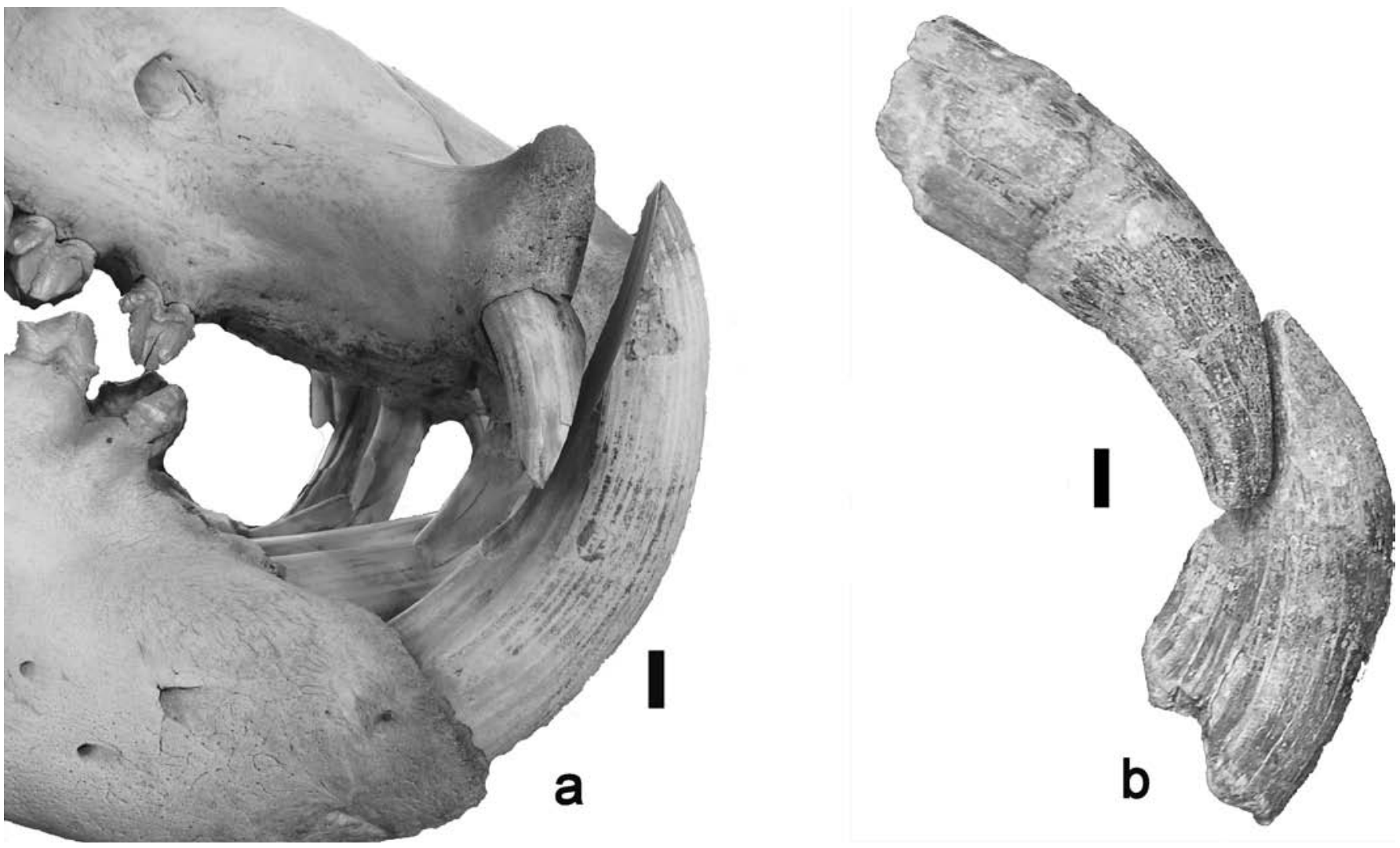

Figure 19. Male canines of (a) Hippopotamus amphibius Linnaeus, 1758 and (b) Libycosaurus petrocchii Bonarelli, 1947, lateral view; (b) is from Pickford, 2006) (scale for Libycosaurus: $10 \mathrm{~mm}$ ). 

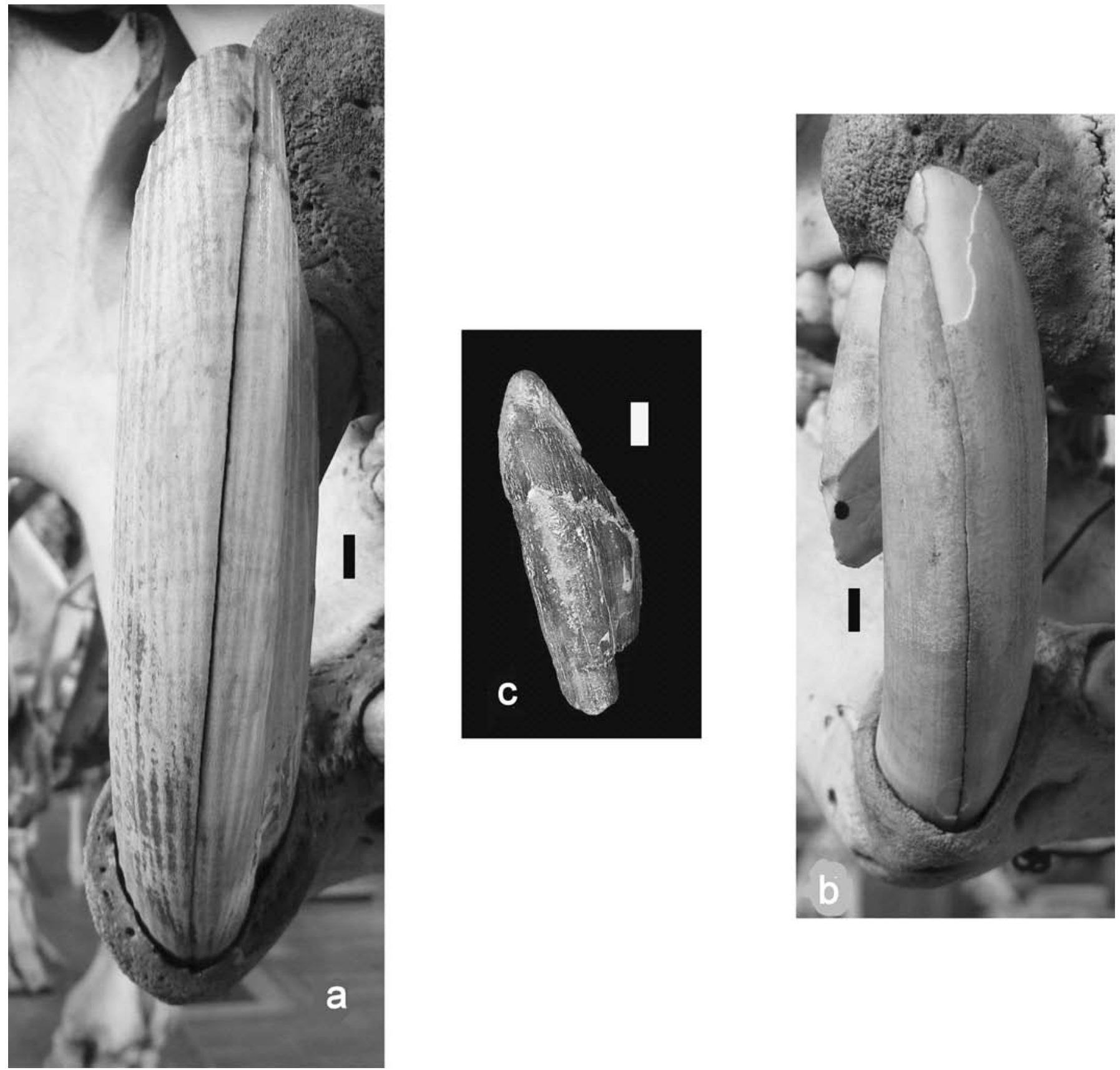

Figure 20. Anterior views of right canines of (a) Hippopotamus amphibius Linnaeus, 1758, (b) Libycosaurus petrocchii Bonarelli, 1947, and (c) Choeropsis liberiensis (Morton, 1849). Note the orientation of the teeth (almost vertical in hippos and dihedral in Libycosaurus) and the tendency for hippo lower canines to split longitudinally (scales: $10 \mathrm{~mm}$ ).

cal and lingual) that are poorly bound to one another, so that the teeth easily split longitudinally, especially when they become desiccated (Fig. 20). Anthracothere canines are seldom if ever found split in half like those of hippos (Fig. 20). Examination of the dentine of lower canines of Merycopotamus and Libycosaurus reveal that it is massive and homogeneous, whereas it is hemicentrically layered in hippopotamids. In the latter group the lower canine is comprised of lingual and buccal halves which are weakly joined along a slightly curved longitudinal junction, the dentine in each part being independently hemicentrically layered. This explains the difference in splitting tendency of these teeth. Surface morphology and internal structure of lower canines comparable to those of hippopotamids is unknown in any anthracotheres, including Libycosaurus and Merycopotamus. This finding weakens the scenario of a close relationship that Boisserie et al. (2005a) postulated between hippos and the latter genera.

A lower canine of Kenyapotamus Pickford, 1983, from Beglia, Tunisia, shows typical hippopotamid morphology 
(Pickford, 2006), meaning that this type of canine existed in kenyapotamines about 12-10 Ma contemporary with Libycosaurus petrocchii.

Boisserie et al. (2005a) concluded that hippo canines, like those of anthracotheres, are sexually dimorphic, contrary to what Pickford (1989) wrote. There appears to be some confusion here between the concepts of dimorphism and bimodality. Although many authors use the word dimorphism for size and/or morphological differences between elements of the two sexes, it is better to differentiate between size differences (bimodality) and morphological differences (dimorphism) and not to amalgamate the two concepts into one word. In fact what Pickford (1989) wrote was that hippo canines were weakly dimorphic, and this is indeed the case, the shapes of male and female canines being similar. Hippo canines are also weakly bimodal, there being a great deal of overlap between the dimensions in males and females. In anthracotheres in general, and in Libycosaurus in particular, the canines are highly sexually dimorphic (Fig. 21) and extremely bimodal (Pickford, 1991, 2006). There is thus a major difference between the degree of canine dimorphism and bimodality in this genus of anthracotheres and hippopotamids.

Every specimen of Libycosaurus preserving the anterior part of the adult upper cheek dentition or the alveolar margin, reveals that this genus was characterised by the presence of an accessory premolar (Pacc in Pickford, 2006).
This was first noted in the Beglia species Libycosaurus petrocchii (= L. anisae) (Fig. 22) and in Libyan Libycosaurus petrocchii by Pickford (1991) and was subsequently reported to occur in Chadian Libycosaurus petrocchii and Libycosaurus sp. nov. (Lihoreau, 2003). The presence of five premolars in Libycosaurus is unique among Artiodactyla, the primitive number of premolars being four, with many lineages, including hippopotami, possessing a tendency to reduce the number of premolars starting at the front of the row.

Boisserie et al. (2005a) referred to one of the characters (comparison of the relative importance of cingular height in palaeochoerids and hippopotamids) used by Pickford (1989) to link palaeochoerids to hippos as being «meaningless». The employment of this adjective suggests that the authors have failed to understand the significance of what Pickford was describing. The molars of some palaeochoerids, like those of early hippopotamids such as Palaeopotamus ternani (Pickford, 1983) (Pickford, 2007) have a crown which sits atop a solidly fused root base, the apices of the roots only separating from this substantial base some distance beneath cervix. In such forms the cingulum is deeper than it usually is in those artiodactyls which have completely unfused roots, including anthracotheres, particularly Libycosaurus. This morphology is relatively rare among mammals, but is common in palaeochoerids (Palaeochoerus, Choeromorus, Lorancahyus Pickford \& Morales, 1998) and typifies kenyapotamines
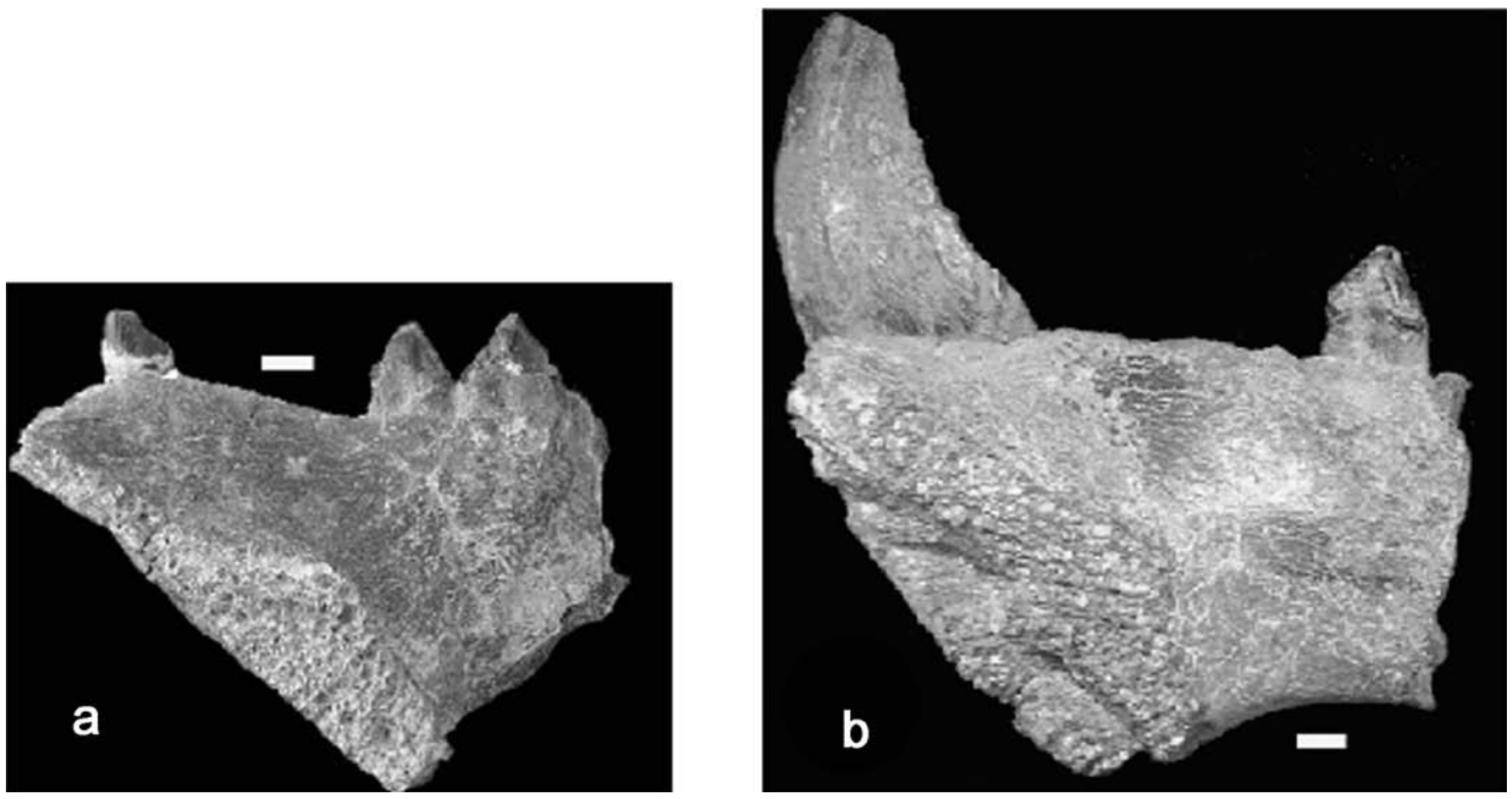

Figure 21. Canine dimorphism in Libycosaurus petrocchii Bonarelli, 1947, (a) female, (b) male, lingual views (from Pickford, 2006) (scale: $10 \mathrm{~mm}$ ). 


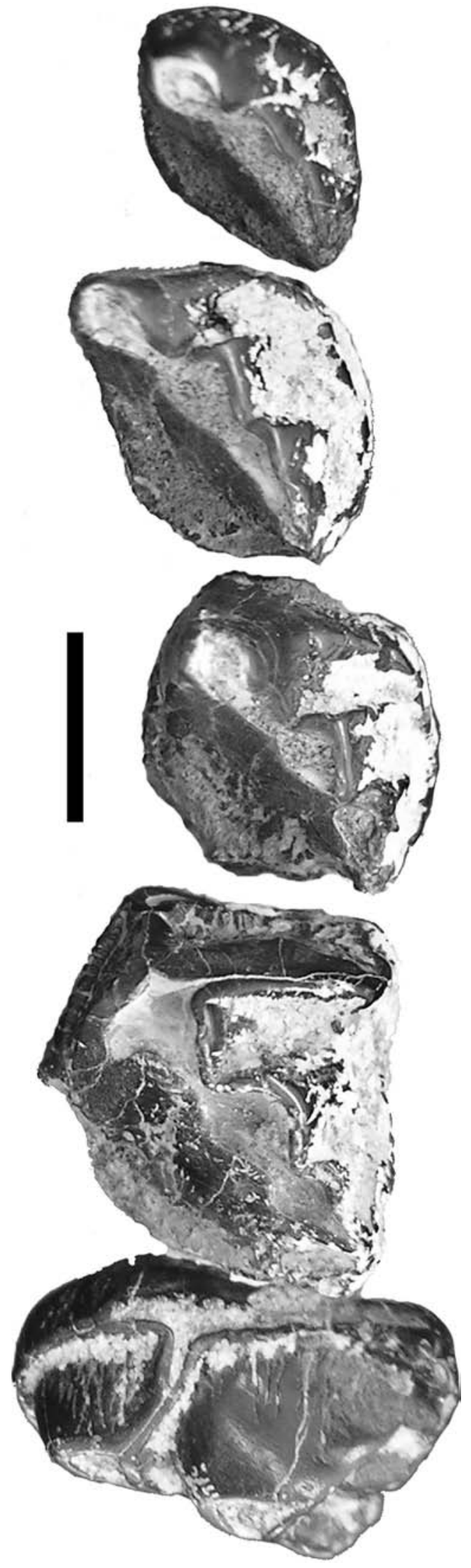

Figure 22. Accessory upper premolar in Libycosaurus petrocchii Bonarelli, 1947. The bicuspid P4/ is preceded by four unicuspid premolars that diminish in size anteriorly (scale: $10 \mathrm{~mm}$ ).
(Palaeopotamus Pickford, 2007, Kenyapotamus Pickford, 1983 ) and in a somewhat subdued form also occurs in hippopotamines. In my opinion such a character provides important evidence of relationships between some palaeochoerids and hippopotamids, and should not be dismissed out of hand as being meaningless.

The upper third molars of Suidae often have a talon (pentacone) behind the four main cusps, and Boisserie et al. (2005b) rightly pointed this out as a significant difference from hippopotamids. However, in their character matrix they scored it as present in the palaeocheorid $\mathrm{Pal}$ aeochoerus, yet it is absent (Hellmund, 1992) a difference that affects their cladistic analysis. The pentacone is also absent in Propalaeochoerus Stehlin, 1899, and Choeromorus (which used to be called Taucanamo) and there is a small cingular cusplet but not a true pentacone in Schizochoerus Crusafont-Pairo \& Lavocat, 1954, all of which are Palaeochoeridae. Neither Kenyapotamines nor Hippopotamines have a pentacone in the M3/, a fact that reinforces the possibility of a relationship between the hippos sensu lato and the palaeochoerids. Re-examination of the fossils attributed to Xenohyus Ginsburg, 1980 (Ginsburg et al., 1988; Pickford \& Morales, 1989; Bouvrain \& de Bonis, 1999) indicates that they are suids, which modifies the evidential basis of the palaeochoerid hypothesis of hippopotamid origins, but does not result in refutation of the hypothesis itself.

Boisserie et al. (2005a, 2005b) considered that pustulate and/or wrinkled tooth enamel was an important character, scored as present in Kenyapotamus, Choeropsis, Hippopotamus, Hexaprotodon, Libycosaurus, and Brachyodus among other taxa analysed, but absent from tayassuids, Doliochoerus and Xenohyus. However, the finely wrinkled enamel that typifies the cheek teeth of the anthracotheres Libycosaurus and Brachyodus is not homologous to the more coarsely wrinkled enamel that occurs in Palaeopotamus, Kenyapotamus and other hippos. Furthermore, the denticles on the premolars of Libycosaurus are not the same as the pustules on the premolars of hippopotamids. Not only do they occur in different parts of the dentition, but also their structure is divergent, denticles being compressed and sharp edged when unworn and pustules being blunt and rounded when unworn. Thus character 60 in Boisserie et al. (2005a) which is the same as character 31 of Boisserie et al. (2005b) represents an amalgam of two categories of morphology a) type of wrinkling (coarse versus fine) and $b$ ) enamel ornamentation (pustules versus denticles) which are not homologous in the taxa examined (Pickford, in press). Therefore inferences drawn about proximity of relationships based on the presence of the amalgamation of these characters in the taxa are invalid. The denticulation of the premolars of Libycosaurus led Bonarelli (1947) to classify this anthracothere as a dinosaur, hence its name. It appears that these denticles continue to cause confusion. 
As was already noted by Falconer (1868) finely wrinkled enamel similar to that in the molars of Merycopotamus occurs in other ruminants, such as the giraffe and the sivathere. Indeed, it was this feature, together with the selenodont morphology and wear pattern of the teeth, and the great difference in the breadths of upper and lower cheek teeth, that prompted Falconer (in Owen, 1845) to name the genus Merycopotamus «merico» meaning ruminant in Greek. In herbivorous mammals wrinkling of enamel in cheek teeth is often associated with a cover of cementum, the wrinkles providing a rugose surface onto which the cementum is bound. Without such a roughened substrate the cementum would tend to spall off during chewing. Fine wrinkling of the enamel such as occurs in Brachyodus and Libycosaurus occurs in many mammalian groups, such as elephantids, suids, hippos and ruminants including cervids, giraffids and some bovids. Taken on its own, this character has almost no phylogenetic signal. Given the widespread occurrence of finely wrinkled enamel in artiodactyls its use by Boisserie et al. (2005a, 2005b) to draw inferences about close relationships between anthracotheres and hippos is suspect.

Pickford (1991) already responded to other proposals that linked the evolution of hippo dentitions from those of anthracotheres.

\section{Dental plasticity}

Boisserie et al. (2005b) wrote that hippo cheek tooth derivative from selenodont teeth of the Bothriodontinae would necessitate a spectacular reversion. In a search for support for this hypothesis which they recognised as being "poorly parsimonious" they appealed to Naylor \& Adams (2001) who wrote that «mammalian teeth could be more plastic than classically suspected, therefore often found to be homoplasic and therefore notably responsible for the discrepancies between molecular and morphological data bearing on cetacean relationships».

I agree that if hippo teeth evolved from an anthracothere dental 'grundplan' (in particular a bothriodontine one) then this would indeed represent a spectacular case of dental plasticity. But before accepting such a scenario, I would like to see evidence for it. Derivation of hippopotamid dental morphology from a palaeochoerid ancestor would require relatively modest adjustments to the dental 'grundplan', with Palaeopotamus and Kenyapotamus providing evidence of how this was achieved (Pickford, 2007). For this reason I am unable to agree with Boisserie et al. (2005b) when they write that «the absence of any known anthracotheriid lineage that also gradually and simultaneously developed hippo-like cranial and dental morphologies is not a decisive argument to reject the strongly supported relationship between
Hippopotamidae and Anthracotheriidae». The concept of dental plasticity strongly opposes the observation by Kowalevsky $(1873$, p. 24) that «Every mammalogist is aware of how constant are the dental characters in large groups of Mammalia».

Finally, in contrast to the hypothesis of dental plasticity, Boisserie (2005) wrote that «hippo cheek teeth show only minor variations, and these variations can be found in most of the known species» thereby confirming constancy of dental morphology among hippopotamines in agreement with Coryndon's (1976, 1977, 1978a, 1978b) and other researchers' writings (Harris, 1991; Pickford, 1993; Harrison, 1997). As such, the concept of dental plasticity as employed in support of derivation of hippopotamids from anthracotheres is unsustainable.

\section{Intermolar size relationships}

Falconer \& Cautley (1836) noted that in Merycopotamus the relationship between the breadths of the lower molar row compared to the upper molar row was comparable to that observed in ruminants (ie lower molars are very narrow compared with uppers) and differed from that in hippos and suids in which the lower molars are not as exaggeratedly narrow. Matthew (1929a) noted that the "bunodont" Artiodactyla possessed molars which had similar lengths and breadths whereas anthracotheres did not. Examination of the dentitions of bunodonts and anthracotheres reveals that the first molar in anthracotheres is appreciably smaller than the second and third molars, whereas in hippos (Fig. 23) suids, palaeochoerids and peccaries the first molar is only slightly smaller than the second and third ones. If anthracotheres are to be the ancestors of hippos, then they would not only have to have undergone "spectacular" modification of their dentitions (Boisserie et al., 2005a) but they would also have had to have modified the intermolar size relationships convergently with other bunodonts at the same time as broadening the lower cheek teeth relative to the upper ones. It is perhaps more parsimonious to conclude, as did Falconer \& Cautley (1836) and Matthew (1929b) that hippo dentitions resemble those of bunodonts, not only in morphology, but also in intermolar relations, because they are part of the same group.

\section{Postcranial evidence}

\section{The neck}

Lydekker (1876) first recorded the presence of a long neck in Merycopotamus based on the elongation of the axis vertebra, which he described as being akin to that of a ruminant. Geais (1934) reported that the neck of Elomeryx borbonicus was similar to that of the wild boar in 

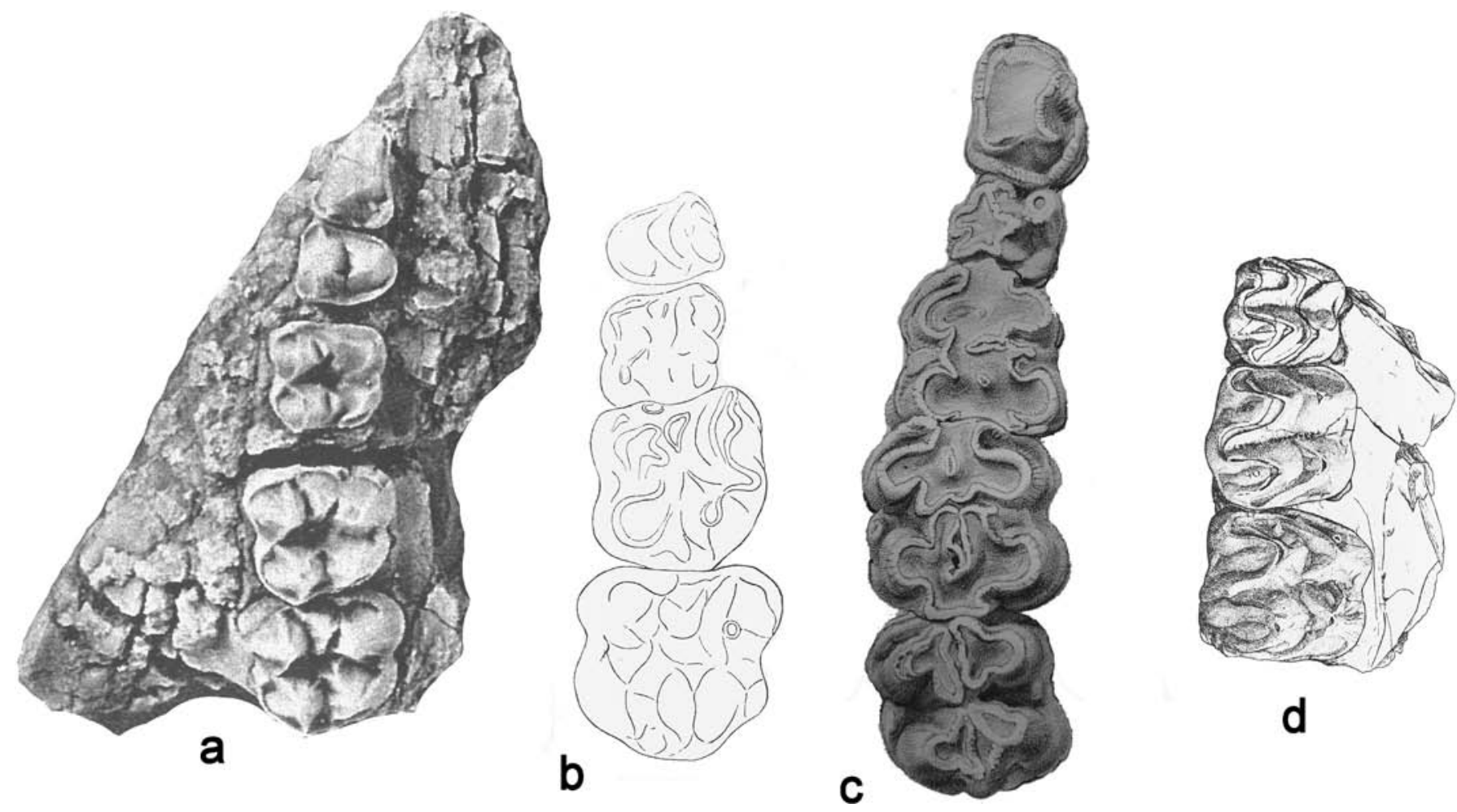

Figure 23. Intermolar size relationships of anthracotheres and hippopotamids, (a) Anthracotherium Cuvier, 1822, from Pondaung, Burma, (b) Anthracotherium magnum Cuvier, 1822, from France, (c) Hippopotamus amphibius Linnaeus, 1758, (d) Libycosaurus petrocchii Bonarelli, 1947, from Beglia, Tunisia (modified from Tsubamoto et al., 2002; de Blainville, 1846; and Black, 1972, respectively) (not to scale).

aspect and dimensions which suggests that the neck was relatively more elongated than it is in hippopotamids. The atlas vertebra of Libycosaurus anisae from Beglia, Tunisia (now classified as L. petrocchii) was first described as a giraffid vertebra (Crusafont-Pairo, 1979) which underlines the observation made by Lydekker (1876) about neck length in bothriodonts, although further evidence about anthracothere neck length would be welcome. A recently discovered cranium of Brachyodus aequatorialis associated with parts of the post-cranial skeleton including the vertebral column, reveal that this bothriodont possessed a long neck.

\section{Limbs}

The failure to include any suiform long bones in the analysis by Boisserie et al. $(2005 \mathrm{a}, 2005 \mathrm{~b})$ is a major weakness of their research programme, mainly because it is essential to include the postcranial skeleton when deducing relationships between artiodactyl groups (Kowalevsky, 1873, 1874; Lydekker, 1876; Matthew, 1929a). Lihoreau (2003) who wrote that, with the exception of the talus and metapodials, he could not distinguish the postcranial bones of the bothriodont anthracothere, Libycosau- rus, from those of hippos. In contrast, Pickford (2006) described many differences between the limb bones of hippos and Libycosaurus petrocchii from Beglia, Tunisia, a finding that is supported by further research on other bothriodonts (see below).

\section{Humerus}

Lydekker (1876) showed that the morphology of the proximal humerus in Merycopotamus was different from that of hippos, notably in the relation of the bicipital groove to the tuberosities and the head, which affects the openness of the groove (Fig. 24).

The morphology of the distal humerus of Libycosaurus, like that of Merycopotamus (Falconer \& Cautley, 1848) is markedly divergent from those of Choeropsis and Hippopotamus. In Hippopotamus amphibius there is a deeply excavated anterior fossa between the epiphysis and the diaphysis. Because of the great depth and expanded surface area of this fossa, hippos can hyperflex their forearm onto the humerus, probably part of the hippopotamid adaptation for running rapidly from land into water and for underwater locomotion (when hyperflexed, the foreleg retracts largely within the thoracic mass leaving only the 

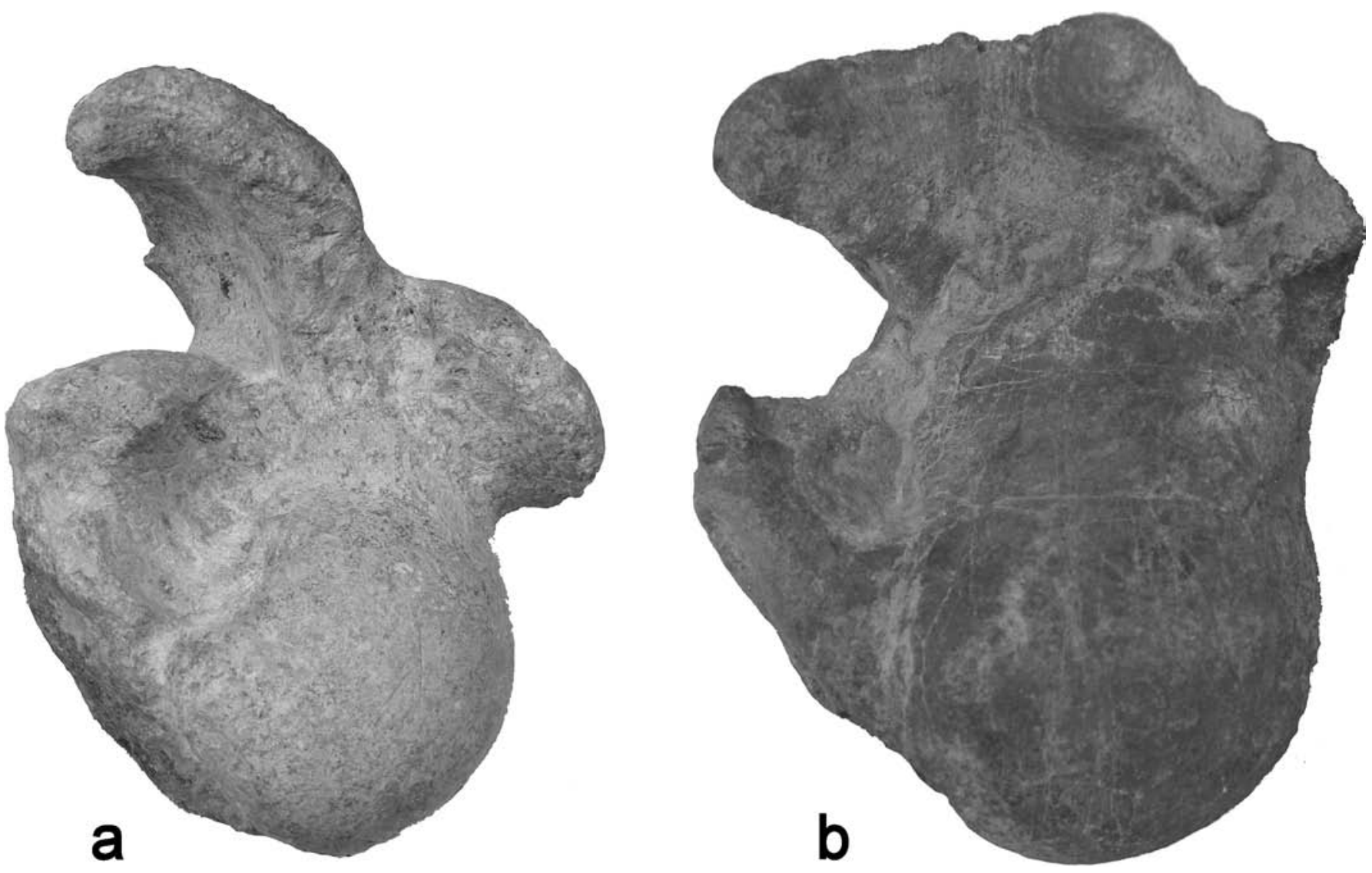

Figure 24. Morphology of proximal humeri of Hippopotamus Linnaeus, 1758, sp. (a) from Sicily) and Merycopotamus dissimilis (Falconer \& Cautley, 1836) (b) from the Upper Siwaliks, India) (not to scale).

distal radio-ulna and feet exposed, thereby streamlining the outline of the body and reducing drag). The distal humeral fossa in Choeropsis is shallower than in Hippopotamus, and thus forearm flexion was less extreme than in the more amphibious hippos. In Hippopotamus madagascariensis Guldberg, 1883, the anterior fossa is also large and in many adult individuals the lateral pillar of the humerus sports a wide groove where the lateral anterior lip of the radius slots into the fossa (Fig. 25). This groove is due to remodelling of the bone rather than to abrasion. This morphology shows an extreme flexion of the forearm towards the humerus in both the Madagascan and African hippos. The fossa in Libycosaurus and Merycopotamus is much less marked, is shallower, and has a smaller surface area. Forearm flexion in these genera was of the ordinary terrestrial mammalian kind, suggesting that in these forms foreleg drag was a likely hindrance to efficient underwater locomotion.

The medial epicondyle in hippo humeri is a low swelling medial to the trochlear margin. In Libycosaurus and Merycopotamus in contrast, the medial epicondyle is extensive and salient, flaring well away from the trochlear margin. There are more subtle differences between the humeri of anthracotheres and hippos, such as the position of the weight-bearing anterior ridge of the diaphysis, which passes slightly medial of the trochlea in hippos, and in line with the medial edge of the trochlea in Libycosaurus. Functionally, the humeri of hippos and Libycosaurus are quite different in detail, the morphological features of the elbow joint indicating divergent locomotor repertoires, a greater degree of flexion of the forearm towards the humerus in hippos, and much less in Libycosaurus and Merycopotamus. Examination of three distal humeri of Brachyodus onoideus (Gervais, 1859) revealed overall similarities to those of Libycosaurus and differences from Hippopotamus.

In posterior view the two distal pillars of the humerus of Libycosaurus form an almost symmetrical Y-shape with respect to the long axis of the diaphysis (Pickford, 2006) (Fig. 26). In hippos, the lateral pillar is in line with the diaphysis, while the medial one diverges strongly (Fig. 26). In lateral view the distal articulation of Libycosaurus is less offset anteriorly than it is in hippos. The deltoid crest is well developed in hippos and descends close to the distal end, but is weakly expressed in Libycosaurus in which it terminates more proximally on the humerus. In the general morphology of the distal humerus hippos are closer to Suoidea than they are to Anthracotherioidea. 

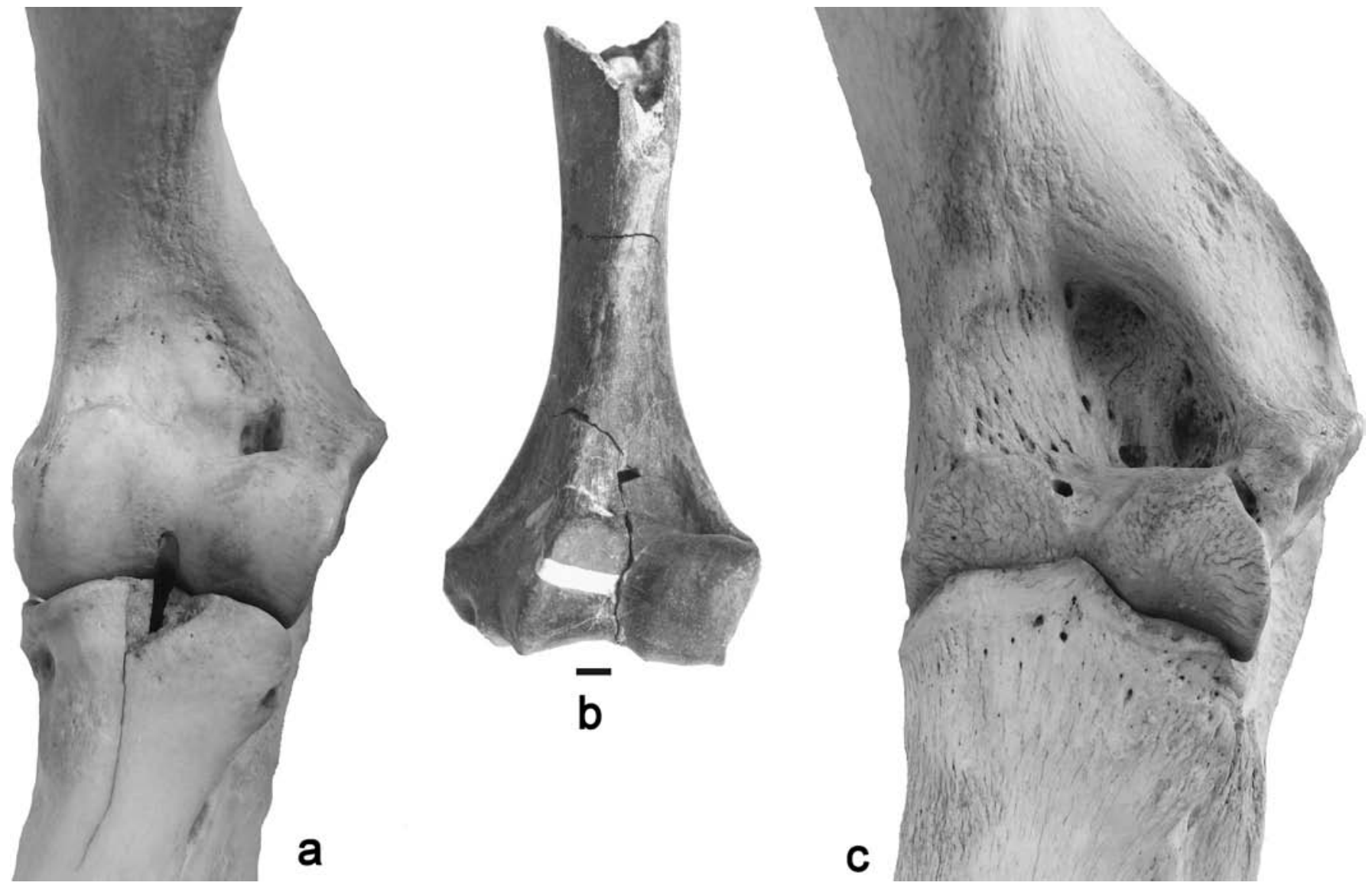

Figure 25. Morphology of distal humeri, anterior views (a) of Choeropsis liberiensis (Morton, 1849), (b) Libycosaurus petrocchii Bonarelli, 1947, from Pickford (2006) and (c) Hippopotamus amphibius Linnaeus, 1758. Note the enlarged, deepened fossa above the distal articulation of hippo humeri, and the shallow fossa in Libycosaurus, the usual artiodactyl condition (scale for Libycosaurus: $10 \mathrm{~mm}$ ).

\section{Radio-Ulna}

The radio-ulna of Merycopotamus, unlike that of hippopotamids, is not ankylosed (Lydekker, 1876). The olecranon process in anthracotheres such as Ancodon is quite straight, almost like those of ruminants (Andrews, 1906) whereas in Hippopotamus and Choeropsis its apex is markedly recurved medially and overhangs an expansive medial fossa (Fig. 27). The olecranon process of Merycopotamus has not been described but the main part of the ulna and the radius are more elongated than the corresponding bones in Hippopotamus (see Lydekker, 1883).

\section{Proximal femur}

In the proximal femur, the anthracothere Libycosaurus petrocchii possesses a prominent and robust tubercle of bone on the anterior aspect of the diaphysis close to the greater trochanter, called the femoral tubercle by Pickford (2006). Somewhat similar overall morphology occurs in
Brachyodus onoideus. Hippos possess a low ridge of bone in roughly the same place, but its form and shape are different. This tubercle is the insertion point of connective tissue that extends between the proximal femur and the pelvis, and serves to prevent the hip joint from becoming disarticulated. In both Hippopotamus and Choeropsis the femoral neck is long whereas in Libycosaurus it is remarkably short (Fig. 28) and this is probably why the tubercle anatomy in the two taxa is different. The greater trochanter in hippos is low and in anterior view does not extend proximally above the head of the femur, whereas in anthracotheres, it is elongated proximally, extending well above the femoral head (Fig. 29). There are thus significant anatomical differences between the proximal femur of this anthracothere on the one hand, and those of hippos on the other.

The hip joint in hippos is more flexible than that of Libycosaurus, which translates into a greater degree of movement of the joint in hippos than in the anthracothere. This is confirmed by the greater sphericity of the femoral head posed on a long femoral neck in hippos, and a slightly less spherical head on a shorter neck in the anthracothere. 


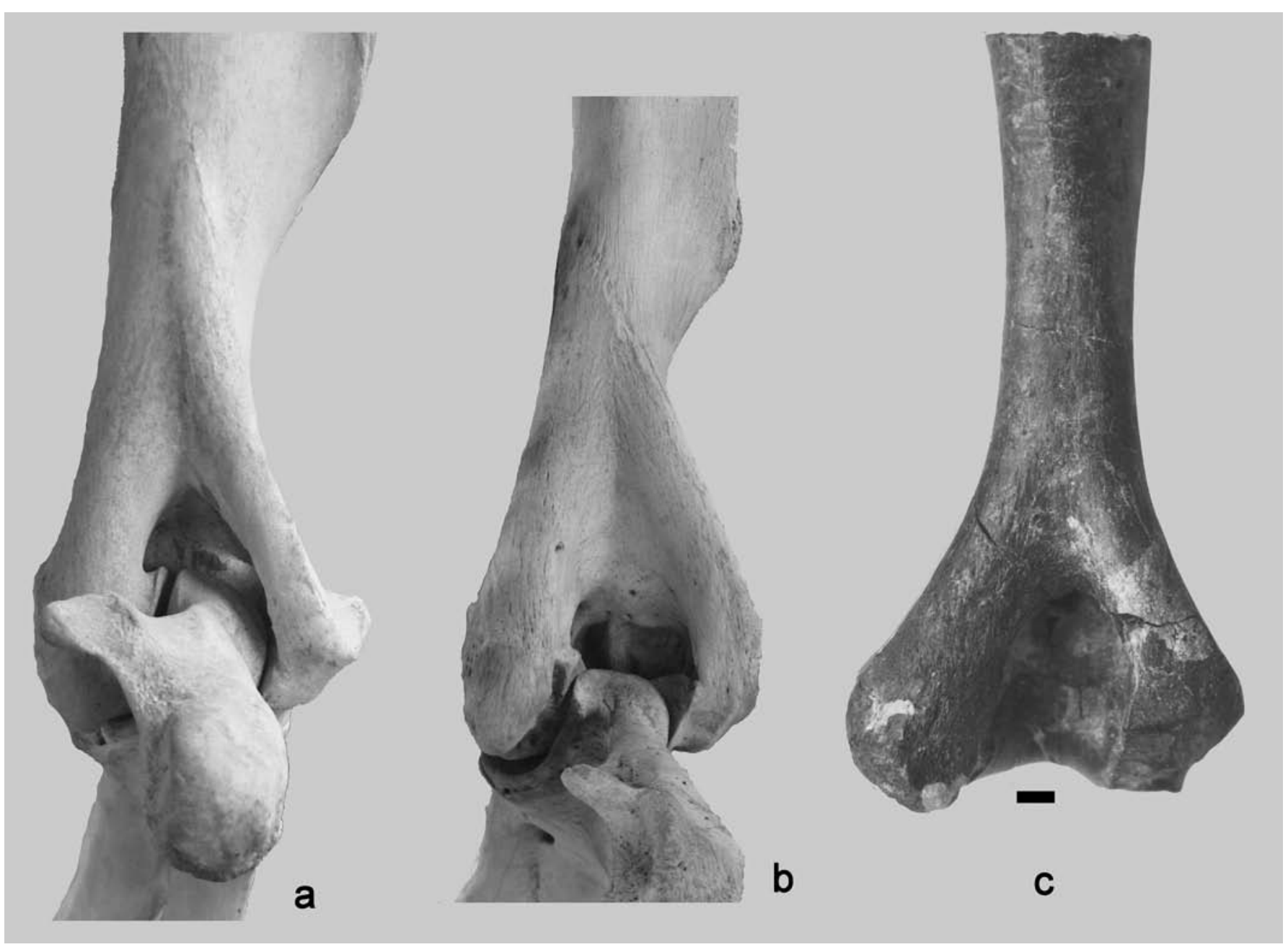

Figure 26. Morphology of distal humeri, posterior views (a) of Choeropsis liberiensis (Morton, 1849), (b) Hippopotamus amphibius Linnaeus, 1758, and (c) Libycosaurus petrocchii Bonarelli, 1947. Note the divergent almost symmetrical pillars in the anthracothere and the asymmetric pillars in hippos, the different development of the lateral pillar of the humerus and the weak deltoid ridge in Libycosaurus Bonarelli, 1947, compared to the large ridge in hippopotamids (scale for Libycosaurus: $10 \mathrm{~mm})$.

From the combined evidence of the elbow and hip joints, it is inferred that hippos had quite a different locomotor style from anthracotheres, with adaptations for running rapidly from land into water, rapid turning and underwater locomotion being better expressed in the hippos.

\section{Distal femur}

NHM M 2712 and NHM M 17979 are distal right femora from the Siwalik Hills, India (Falconer \& Cautley, 1848; Lydekker, 1885) (Fig. 30, 31). The most striking features of NHM M 2712 are the extensive and deep supracondyloid fossa, the subequal development of the trochlear lips, the greater development of the lateral supratrochlear ridge in contrast with that of the medial supratrochlear ridge, and the well defined supratrochlear depression.
The supracondyloid fossa is about $16 \mathrm{~mm}$ broad and 45 $\mathrm{mm}$ long and has an extremely rugose surface comprised of dense bony tubercles. Its margins are steep and overhang the fossa, unlike the shallow depression that occurs in hippos and the lack of depression in suids. In this feature the specimen more closely resembles equids than other artiodactyls. The two condyles are subequal in dimensions.

In most ungulates the lateral supratrochlear ridge is lower and more weakly developed than the medial one. However, in NHM M 2712, the lateral ridge is higher and thicker than the medial one, and it closes off the supratrochlear depression on its lateral side. As a result, the supratrochlear fossa is narrow and deep and does not slope markedly laterally. With the femoral condyles posed flat on a horizontal surface, it is seen that the trochlear gully is not as steeply inclined as it usually is in ungulates, in this respect being closer to the situation in suids than in other 


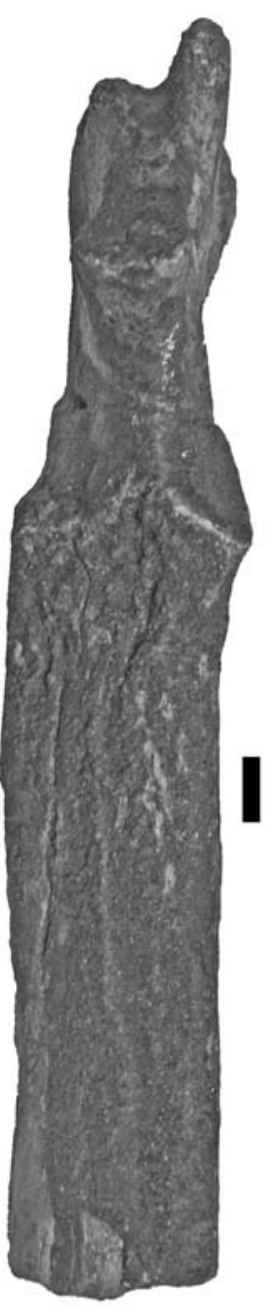

a

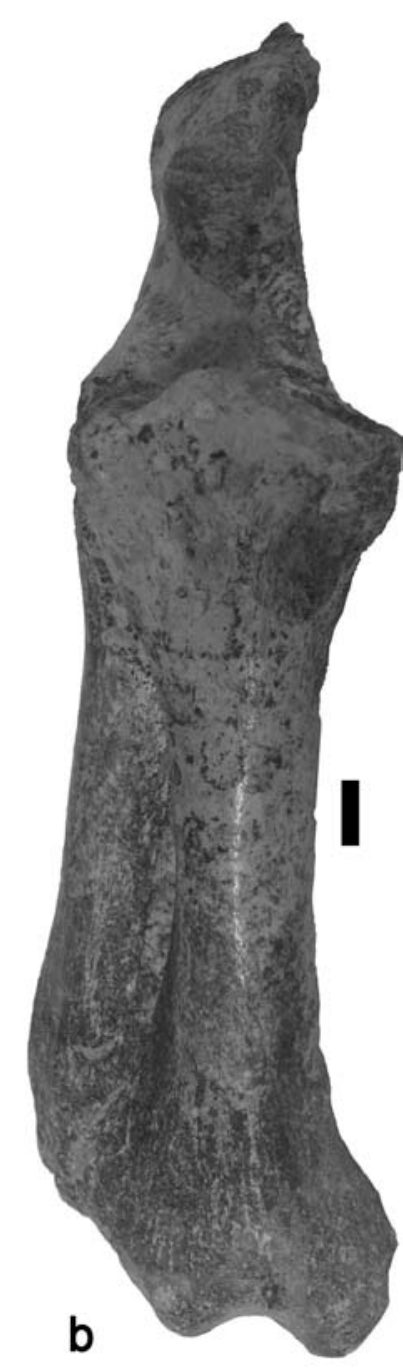

Figure 27. Morphology of the proximal ulna in anthracotheres (a) Ancodon gorringei Andrews, 1906, from the Fayum, Egypt, and hippopotamids (b) Hippopotamus sp. from Cyprus. The straight and medio-laterally flattened olecranon process of Ancodon contrasts strongly with the curved process of the hippo which is deeply excavated on its medial side (scale for Ancodon Pomel, 1847: $10 \mathrm{~mm}$ ).

suiforms. The medial trochlear lip is slightly inflated and is marginally bigger and taller than the lateral one. This conformation is quite different from the greatly expanded medial lip that occurs in hippos and most ruminants, and in this feature the Siwalik specimen is closer to suids than to other artiodactyls.

In NHM M 2712, the fossa for the femoro-metatarsal ligament is well developed, invaginating between the base of the trochlea and the lateral condyle. Damage in this area does not reveal whether there is a continuity between the trochlear and condyloid articular surfaces, although it seems likely that there was. The popliteal fossa is a well developed hemispherical depression.
NHM M 17979, a distal left femur (Falconer \& Cautley, 1848; Lydekker, 1885) is not as well preserved as NHM M 2712, but on the basis of its dimensions and morphology it evidently belongs to the same species (Fig. 30). The condyles and trochlea have been abraded, and there is still matrix in the supracondyloid fossa and the depression for the femoro-metatarsal ligament. The outline of the supracondyloid fossa indicates that it is deep and has overhanging walls. The supratrochlear fossa is extensive and even though the supratrochlear ridges are abraded it is evident that the lateral one was originally taller and broader than the medial one. Sediment filling the fossa for the femorometatarsal ligament prevents proper assessment of its morphology, but what is visible conforms with the situation in NHM M 2712. The popliteal fossa is shallow and weak. Lydekker (1876) described the condyles of this specimen as being sub-equal in size. This is indeed so, even though abrasion to the condyles has altered their appearance.

NHM G 12 is a distal left femur from Gebel Zelten, Libya, attributed to Sivameryx africanus (Andrews, 1914), a species which is common at the locality (Pickford, 1991). In general it is well preserved but it has suffered slight damage near the zone of the origin of the femorometatarsal ligament (Fig. 31). The supracondyloid fossa is deep with overhanging walls and its surface is adorned with dense bony tubercles. The fossa is $20 \mathrm{~mm}$ broad, but its length cannot be determined as its proximal part is broken off. In cranial aspect it is clear that the lateral supratrochlear ridge is taller and broader than the medial one, whereas the medial trochlear lip is more inflated and slightly taller than the lateral one. The fossa for the femoro-metatarsal ligament is deep and broad, but its medial edge is damaged so it is not possible to determine whether the trochlear and condylar articular surfaces were continuous or not. The popliteal fossa is weakly expressed. In distal view, it is possible to see that the intercondyloid fossa is separated into two moieties by a well developed ridge which separates the insertions for the cruciate ligaments. The crest delimiting the insertion of the medial head of the gastrocnemius is well defined. With the two condyles placed horizontally, the trochlear gulley is seen to be more weakly inclined than it is in hippos and most other artiodactyls other than suids. The two condyles are subequal in size.

Specimen OMD 93'28, housed in the Oranjemund $\mathrm{Mu}-$ seum, Namibia (Pickford, 2003) is an almost complete femur of Brachyodus aequatorialis MacInnes, 1951, lacking only the head and neck, collected at Auchas, Orange River valley from deposits aged about 19 Ma (Fig. 30). It is reconstructed from three pieces, and there is some plaster-of-paris infilling missing pieces of cortex, including parts of the supracondyloid fossa. It has a large and deep supracondyloid fossa, judging from the proximal and distal portions which are well preserved. The medial supratrochlear ridge is slightly higher and better devel- 

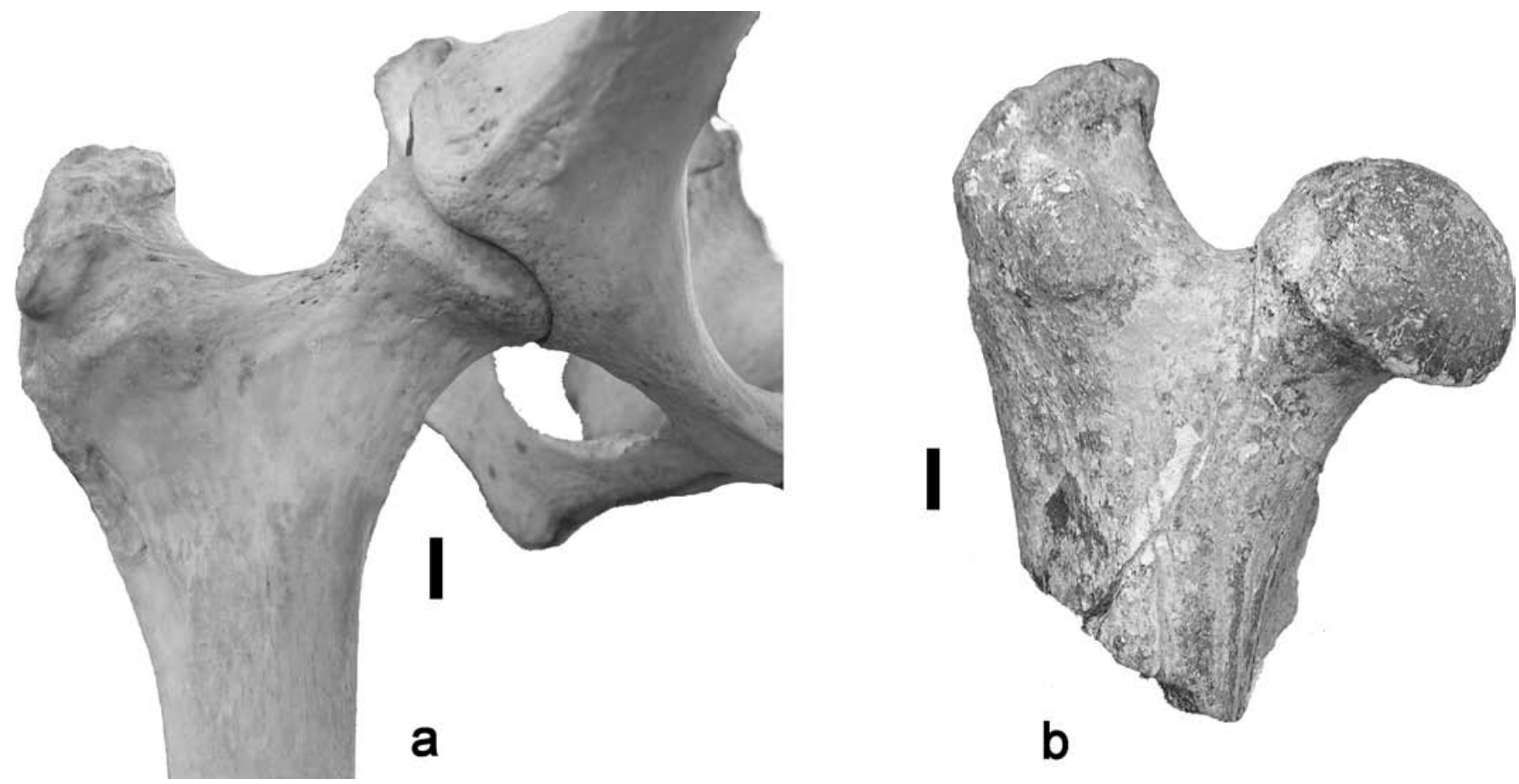

Figure 28. Femoral neck length in (a) Hippopotamus amphibius Linnaeus, 1758, right femur and (b) Libycosaurus petrocchii Bonarelli, 1947, right femur from Beglia, Tunisia. The femoral neck is long in hippos and short in anthracotheres (scale: $10 \mathrm{~mm}$ ).
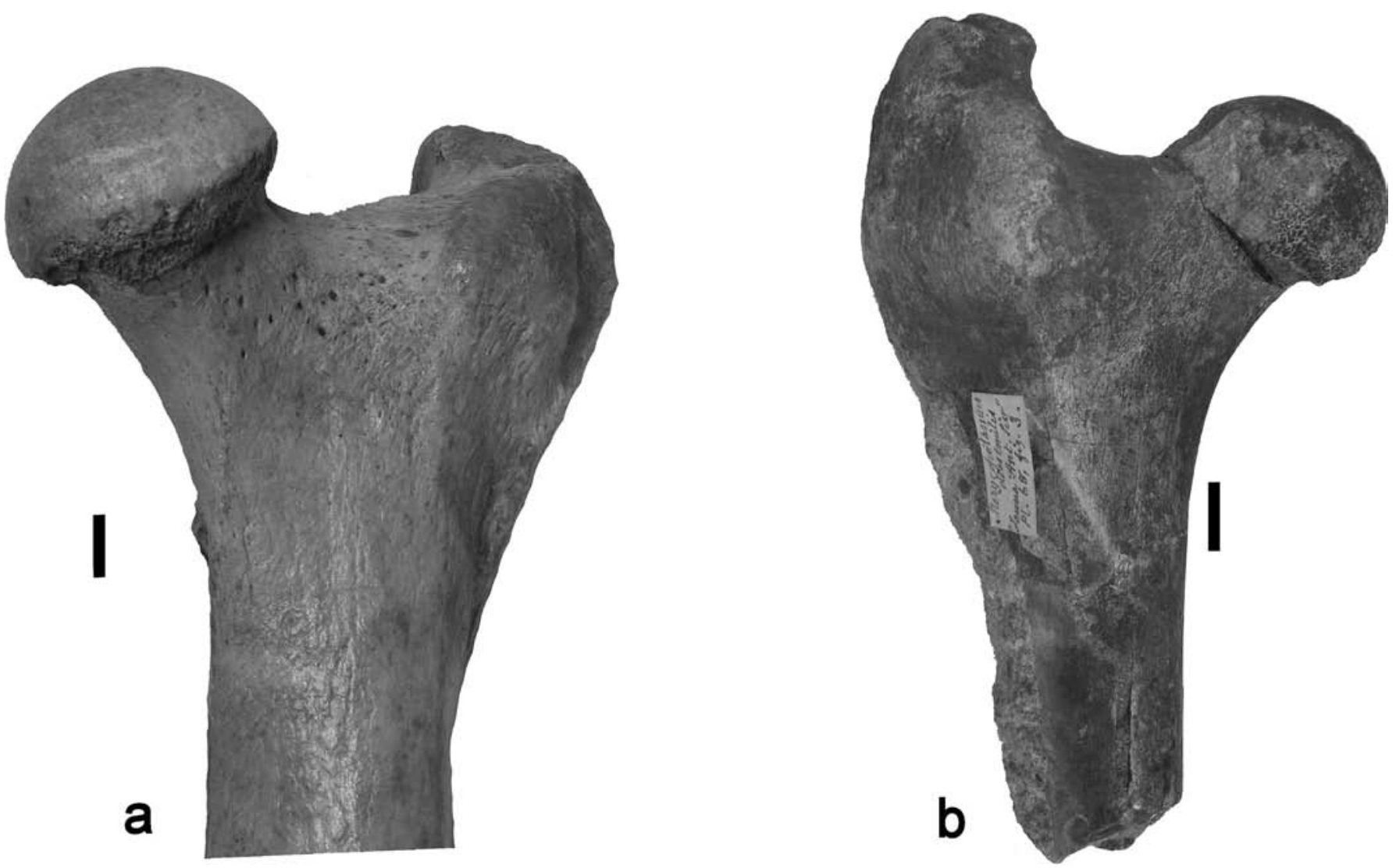

Figure 29. Projection of the greater trochanter above the femoral head in (a) Hippopotamus madagascariensis Guldberg, 1883, left femur, and (b) Merycopotamus Falconer \& Cautley, 1848, right femur from the Upper Siwaliks, India. The femora are oriented with the anterior border of the diaphyses parallel to each other. In hippos the trochanter terminates beneath the level of the head, whereas in anthracotheres it projects well above the head (scale: $10 \mathrm{~mm}$ ). 

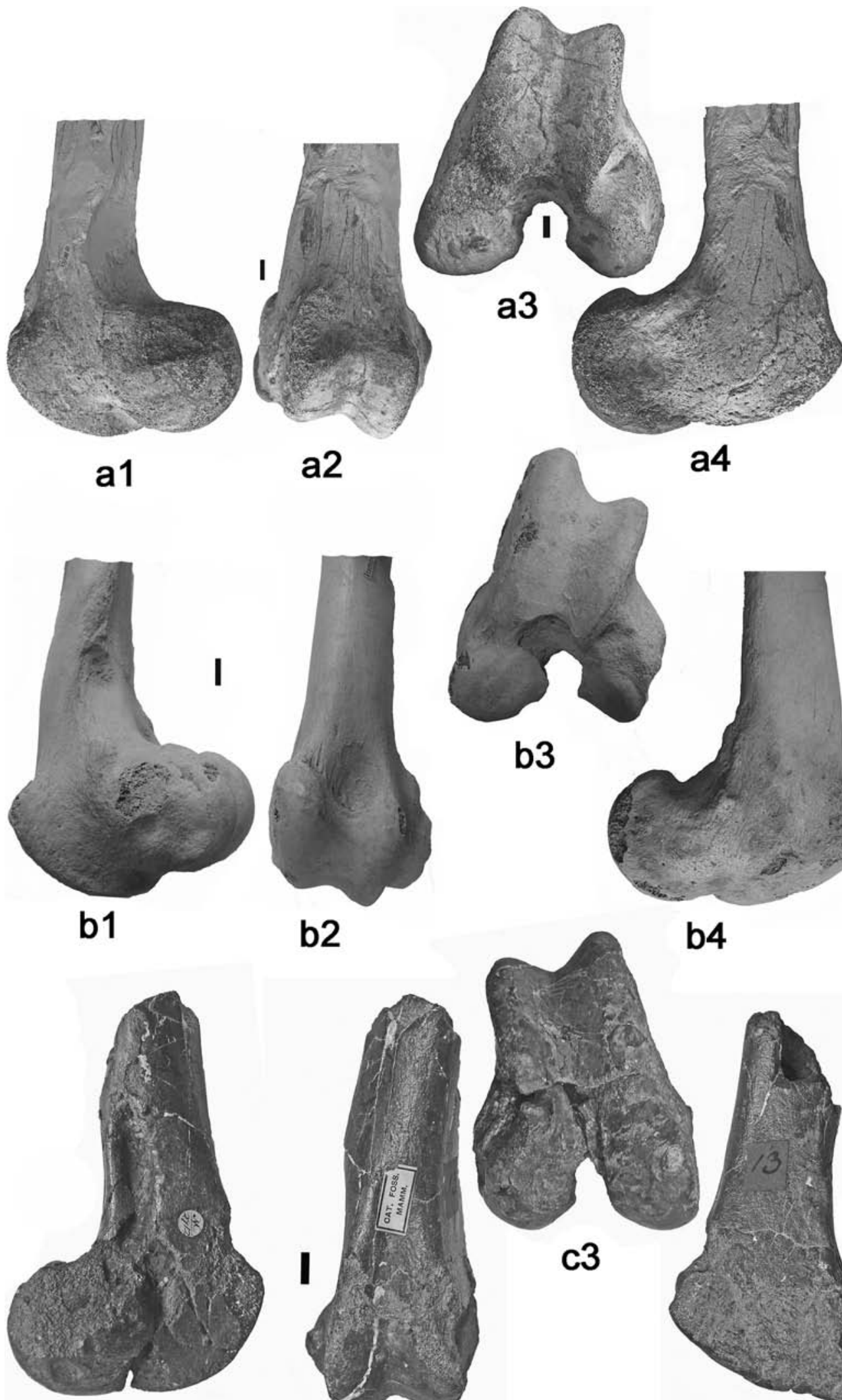

c1

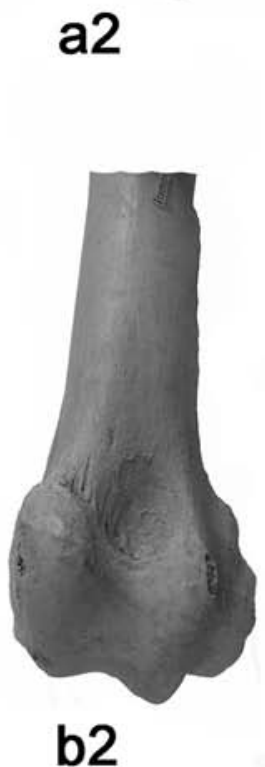

a4

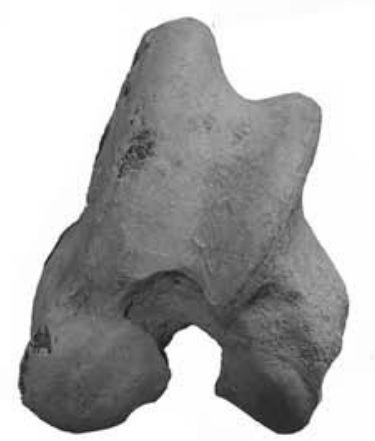

b3

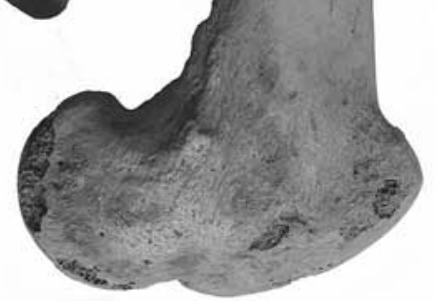

b4

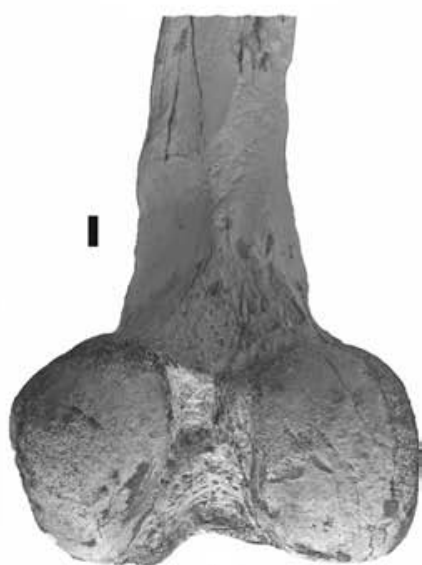

a5

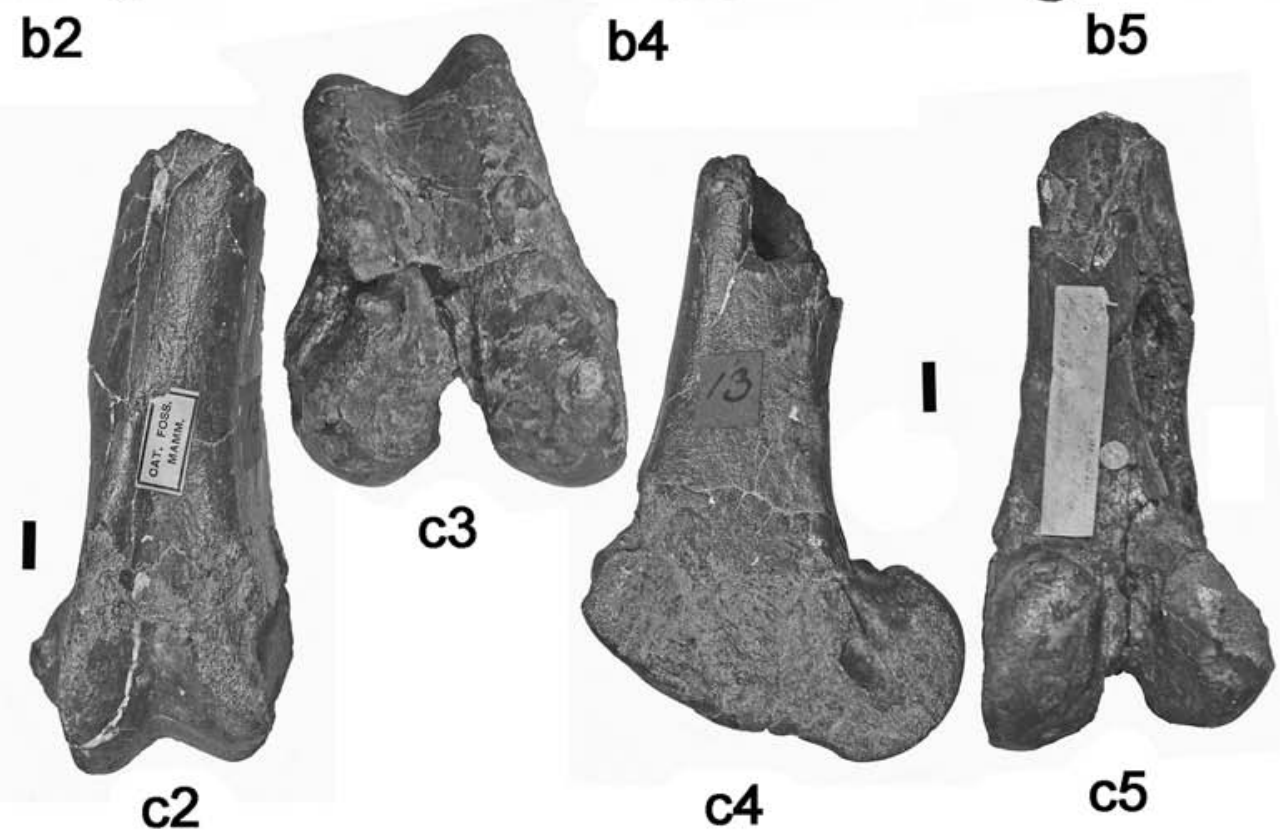

Figure 30. Distal femora of anthracotheres and hippos, (a) OMD 93'28, Brachyodus aequatorialis MacInnes, 1951, left femur from Auchas, Orange River Valley, Namibia, (b) NHM M 4953, Hippopotamus sp. left femur from Itampulu Vé, Madagasacar, (c) NHM M 2712, Merycopotamus dissimilis (Falconer \& Cautley, 1836), right femur from the Siwalik Hills, India (scale bar: $10 \mathrm{~mm}$ ). 


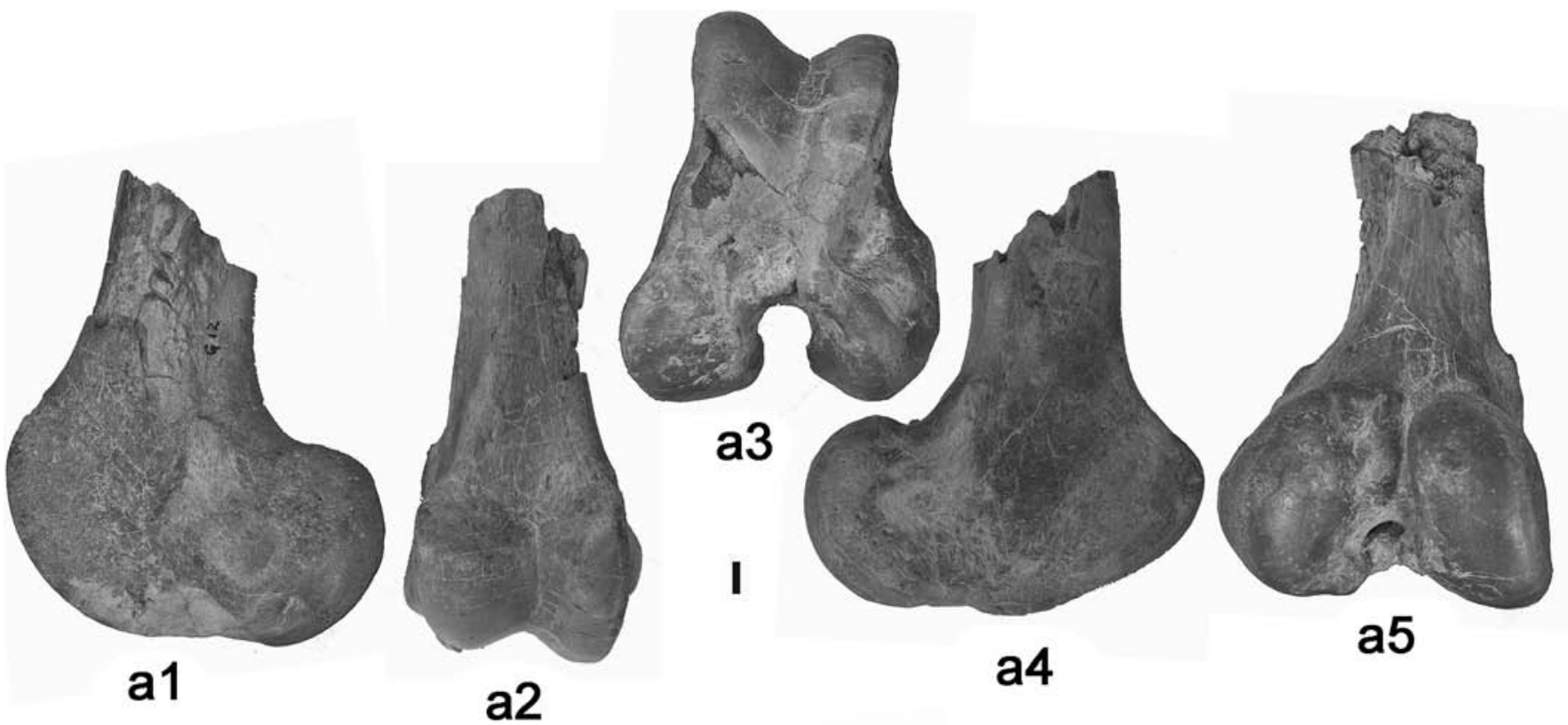

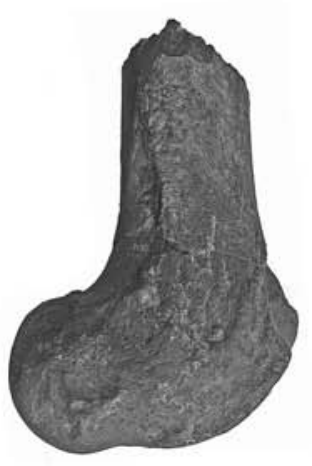

b1

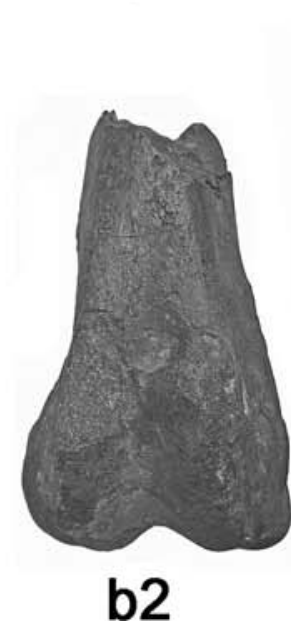

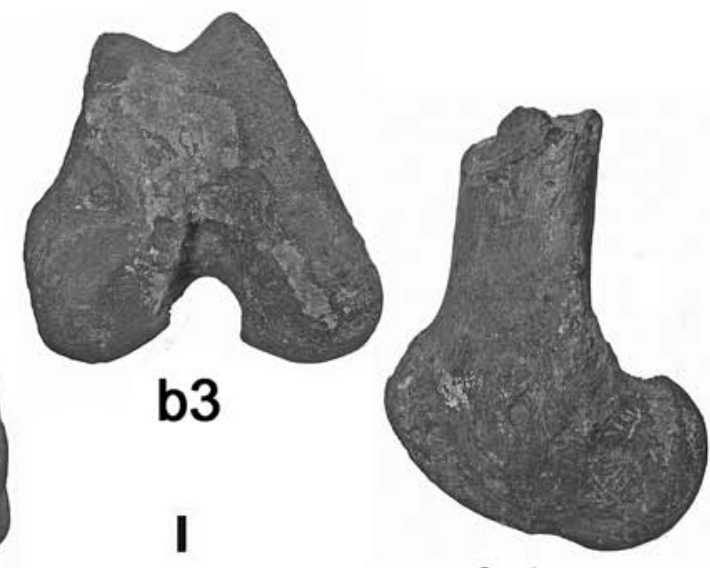

b4

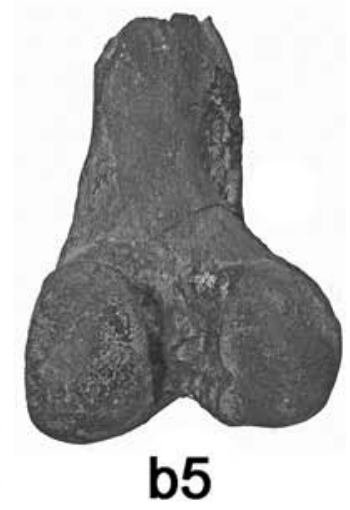

Figure 31. Distal femora of anthracotheres and hippos, (a) NHM G 12, Sivameryx africanus (Andrews, 1914), left femur from Gebel Zelten, Libya, (b) NHM M 17979, Merycopotamus dissimilis (Falconer \& Cautley, 1836), right femur from the Siwalik Hills, India (scale bar: $10 \mathrm{~mm}$ ).

oped than the lateral one, and the supratrochlear depression is shallow and slopes slightly laterally. The medial supratrochlear lip is low dorsally, although the specimen is abraded in this part which makes it difficult to interpret. However, the dorsal part of the lip was probably not very much higher than the lateral one. With the condyles placed horizontally, the trochlear groove is only slightly inclined. The popliteal fossa is shallow but extensive, and the fossa for the femoro-metatarsal ligament is deep and extensive, separating the articular surface of the trochlea from that of the lateral condyle. The two condyles are sub-equal in dimensions and the intercondyloid fossa is broad and has a wide transverse ridge separating the proximal and distal fossae for the cruciate ligaments. The posterior fossa for the cruciate complex is closed distally by a sharp edged ridge.
In overall morphology the Auchas anthracothere femur resembles that of Merycopotamus and Sivameryx, despite its considerably greater dimensions. The only significant difference is that the medial supratrochlear ridge is higher than the lateral one but the difference in development of these ridges is much less than it is in Hippopotamus.

NHM M 4953, a femur of Hippopotamus from Itampulu Vé, Madagascar, was studied because it is from a small species, its femur being about the same dimensions as that of Merycopotamus dissimilis described above (Fig. 30). The supracondyloid fossa is shallow and does not show any signs of overhanging walls. The bone surface in the fossa and its surroundings is roughened by low crests and fine tubercles. The medial trochlear lip is much higher and more inflated than the lateral one, as in Hippopotamus amphibius. The medial supratrochlear ridge is much higher 
and broader than the lateral one. The supratrochlear fossa is well developed and slopes laterally. The fossa for the femoro-metatarsal ligament is shallow and there is a gap between the articular surfaces of the trochlea and the lateral condyle. The popliteal fossa is weak, barely discernible. In this specimen, as in other hippo femora studied, the lateral condyle is considerably smaller than the medial one, such that when the condyles are posed horizontally, the trochlear gulley is more inclined than it is in Sivameryx from Gebel Zelten, Brachyodus from Auchas and Merycopotamus from the Siwaliks.

\section{Tibia}

The morphology of the proximal epiphysis of the tibia of hippos and anthracotheres (in particular that of Merycopotamus) are radically different (Fig. 32). In Hippopotamus, the medial articular surface is more expansive than it is in anthracotheres, extending anteriorly and laterally further than in the anthracothere. The lateral articular surface in contrast, is appreciably smaller in the hippo than in anthracotheres. Related to these articular differences, are the position and shape of the notch at the proximal end for the politeal and the peroneus tertius (femoro-metatarsal ligament) which in anthracotheres is narrow, close to the anterior tuberosity and opens more anteriorly than laterally, whereas in Hippopota$m u s$, it is considerably wider and opens laterally.

The proximal tibia of Merycopotamus dissimilis was already compared by Lydekker (1876) to those of hippos and suids. In proximal view the most striking difference between Merycopotamus and Hippopotamus concerns the relative sizes of the medial and lateral articulations for the femoral condyles. In the anthracothere, the two surfaces are subequal in dimensions, whereas in hippos the lateral articular surface is considerably smaller than the medial one, paticularly in its antero-posterior dimensions. As a result of this, the groove for the popliteal muscle and the femoro-metatarsal ligament opens antero-laterally in the anthracothere whereas it faces largely laterally in hippos. Furthermore the groove is relatively narrower in anthracotheres than in hippos. Linked to this morphology is the position of the fossae for the cruciate ligaments, which are located in the antero-posterior midline of the proximal surface in anthracotheres, whereas in hippos the anterior fossa is positioned well laterally from the midline, the posterior one being in the midline.

In Brachyodus aequatorialis from Gebel Zelten (NHM M 17) the two articular surfaces of the proximal tibia are subequal, the popliteal groove is narrow and opens antero-laterally, and the two fossae for the cruciate ligaments are aligned with the antero-posterior midline of the bone. The same conformation is seen in a specimen from Arongo Uyoma (NHM M 32726) and Rusinga (NHM M 32938) (Kenya) (Fig. 32).

\section{Interpretation of the musculo-tendinal system of the knee joint of anthracotheres}

The morphology of the distal femur and proximal tibia of bothriodonts stands out from the remainder of the suiform artiodactyls to such an extent that it suggests that their locomotor repertoires were markedly different. The great development in the femur of the supracondyloid fossa together with its extremely rugose denticulate surface indicates that the superficial flexor of the digits was relatively more powerful than in other suiform artiodactyls. The insertions for the gastrocnemials (lateral and medial heads) are well developed and extensive. This combination indicates that leaping or bounding were probably an important element of the locomotor repertoire of bothriodonts, analogous in ways to the gallop and jumping performed by equids. The fossa for the femoro-metatarsal ligament (peroneus tertius) in bothriodonts is deep and large, as in equids, whereas in suids and hippos its area of origin is relatively smaller. In horses this ligament comprises part of the lower limb stabilising mechanism that allows them to sleep in a standing position (Sisson \& Grossman, 1953). It also acts as a spring-like ligament automatically bringing the metatarsals into an extended position during locomotion. The position of the fossae for the cruciate ligaments in the anthracothere proximal tibia suggests a parasagitally constrained flexion-extension movement of the knee joint in anthracotheres, whereas in hippos the movement is strongly oblique to the parasagittal plane.

\section{Talus}

The proximal extension of the sinovial fossa in the talus (the digital fossa in Boisserie et al., 2005a, 2005b) is highly variable in artiodactyls. In general large artiodactyls such as Bos Linnaeus, 1758, and Syncerus Hodgson, 1847, have a fossa that extends proximally well into the region between the lateral and medial tibial articular facets, sometimes as far as the proximal extremity of the bone, whereas smaller artiodactyls tend to have a small extension proximally or none at all, although there are exceptions such as Capra Linnaeus, 1758. Thus a comparison between hippos on the one hand, both extant genera of which are large mammals, and Potamochoerus Gray, 1854, and Sus on the other, both of which are medium sized suids, would be expected to show allometric differences in sinovial fossa extension proximally. As soon as we include larger suids in the comparison, the distinction tends to break down, species such as Libycochoerus massai Arambourg, 1961, sometimes having a marked but not very deep extension.

Among the 22 tali of Brachyodus onoideus from the French Faluns (Dineur, 1981) that I studied 19 had no sign of a proximal extension of the sinovial fossa, and 

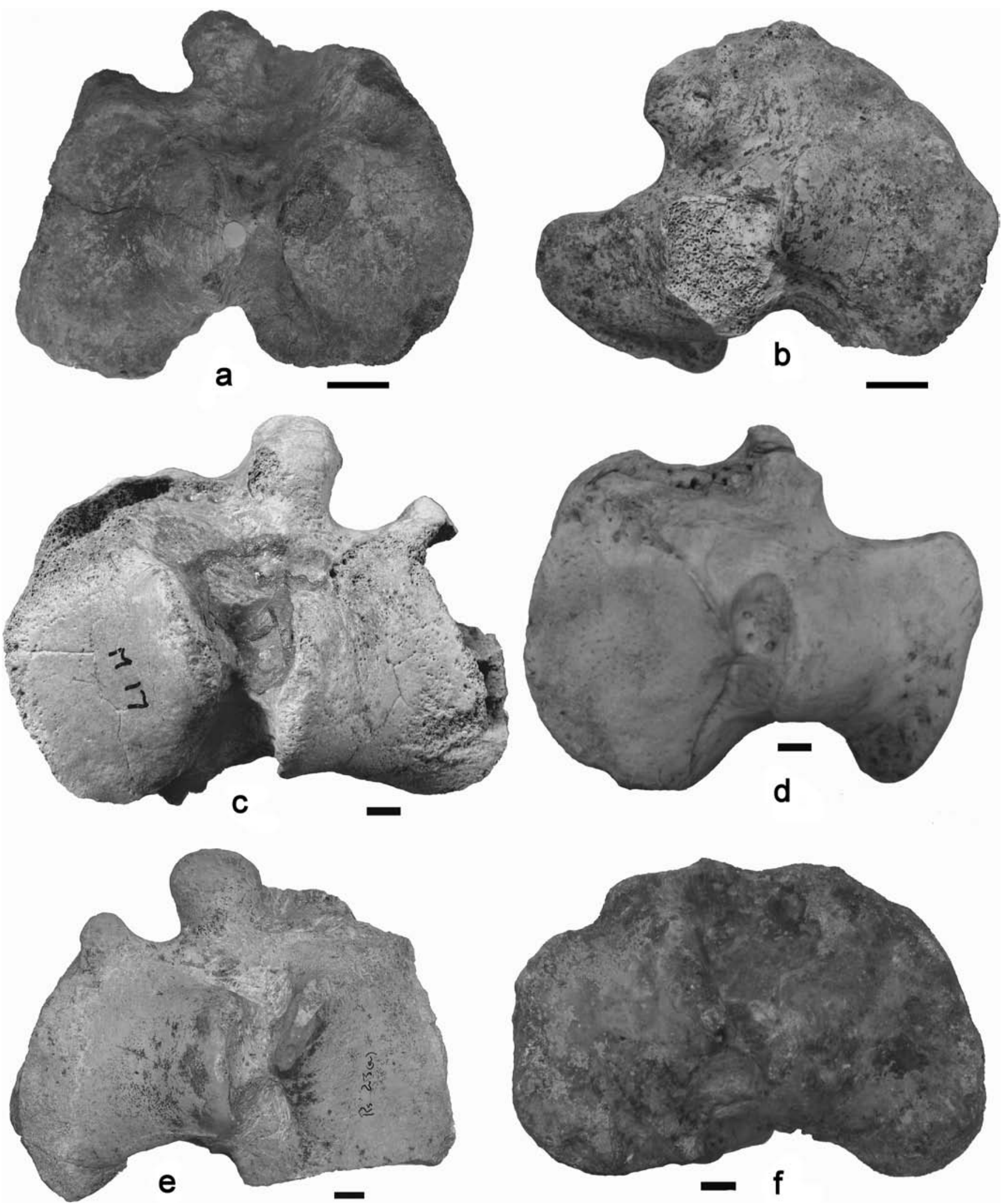

Figure 32. Proximal tibia of anthracotheres and hippos, (a) NHM M 17980, Merycopotamus dissimilis (Falconer \& Cautley, 1836), left tibia from the Siwalik Hills, India, (b) Hippopotamus sp. Itampulu Vé, Madagascar, (c) NHM M 17, Brachyodus aequatorialis MacInnes, 1951, left tibia from Gebel Zelten, Libya, (d) Hippopotamus amphibius Linnaeus, 1758, NHM, un-numbered specimen, right tibia, (e) NHM M 32938, Brachyodus aequatorialis, proximal left tibia from Rusinga (RS 23a) Kenya (note broken caudal part of medial articulation) (f) NHM M 32826, Brachyodus aequatorialis, damaged right tibia from Arongo Uyoma, Kenya (scale bar: $10 \mathrm{~mm}$ ). 
three had a shallow roughened area between the lateral and medial articulations for the tibia, somewhat similar to the condition in the suid Libycochoerus massai. Boisserie et al. (2005a) scored the proximal extension as present in the species Brachyodus aequatorialis but it is absent in the Egyptian and Namibian specimens attributed to the closely allied species Brachyodus depereti Fourtau, 1918 (Fourtau, 1920, Fig. 55; Pickford, 2003, Pl. 3). Although MacInnes (1951) did not illustrate the talus of this species, in the description he made no mention of the existence of the proximal extension of the sinovial fossa, although he did say that the talus was «similar in form to that of a hippopotamus, though distinctly more elongate». My own observation of tali of Brachyodus aequatorialis from Rusinga, Kenya, shows no evidence of the anterior extension of the sinovial fossa, and there is none in specimens from Gebel Zelten (Libya), Wadi Moghara (Egypt) and Grillental (Namibia). Its absence in another closely related species Brachyodus onoideus from Europe (Zbyszewski, 1949, Pl.
10) indicates that it has probably been incorrectly scored by Boisserie et al. (2005a). The value of this character for phylogenetic analysis is thus minimal, perhaps worthless without more precise definition.

Examination of anthracothere and hippopotamid tali reveals that they are not particularly similar to each other, as has often been assumed in the past. Similarities exist, but that is because they are Suiformes, but their detailed anatomy and proportions diverge significantly (Fig. 33, 34). For example, tali of anthracotheres such as Brachyodus usually possess a prominent projection on the lateral side. Most hippopotamids do not have a comparable protuberance, or if they do it is of low stature. The tibial trochleae of anthracothere tali are of uniform width throughout their extent, whereas hippo tali broaden abruptly laterally towards their anterior proximal extremity and have an extensive swelling of bone lateral to this broadening. The distal tibia shows concordant differences in morphology. The length-breadth proportions of the tali are extremely

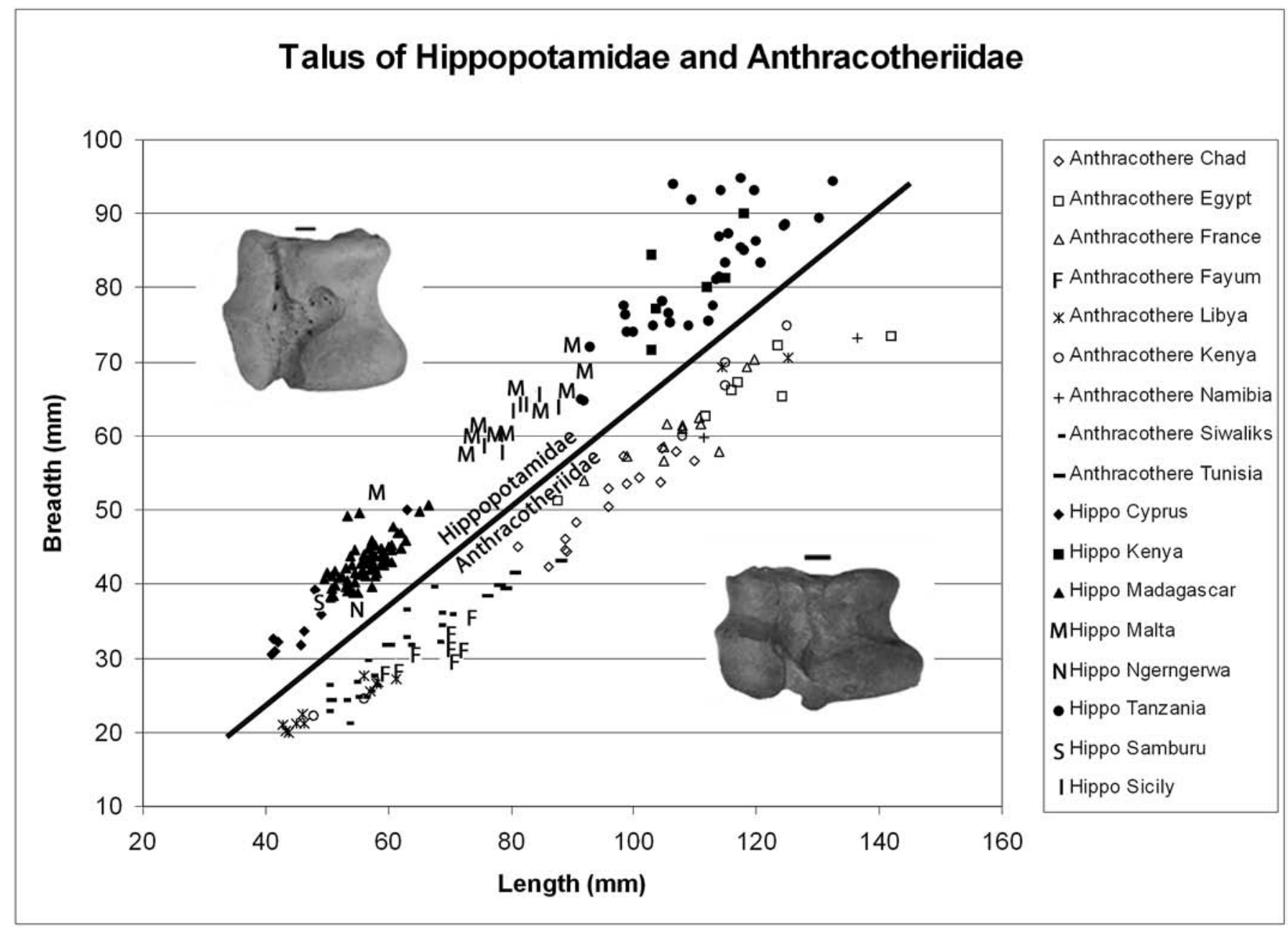

Figure 33. Length-breadth relationships of 102 anthracothere (below the sloping line) and 142 hippopotamid tali (above the line) from many different localities and time periods. All hippopotamid tali, including those of Kenyapotamus Pickford, 1983, are broader relative to length than all anthracothere tali, regardless of the overall dimensions or the geological age of the specimens measured. (Left tali illustrated are in anterior view: proximal is to the right) (scale $10 \mathrm{~mm}$ ). 


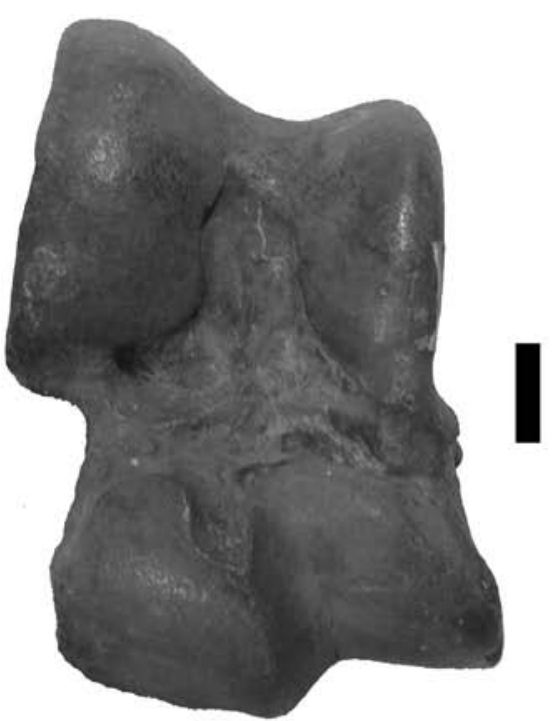

a

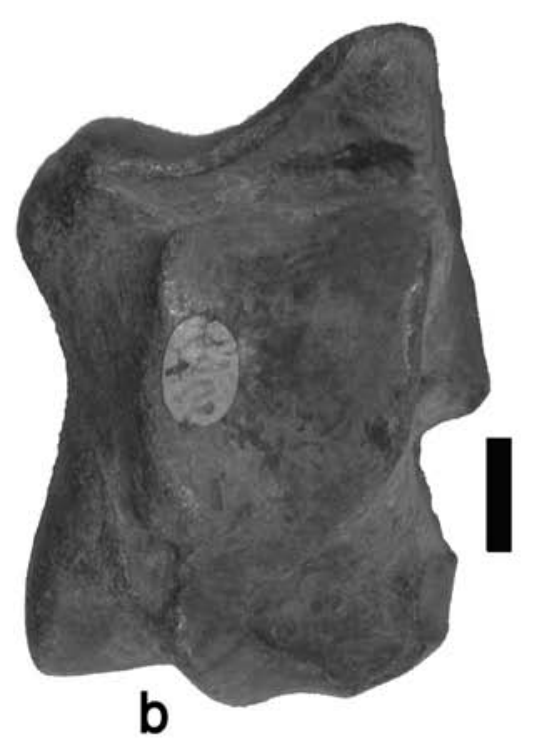

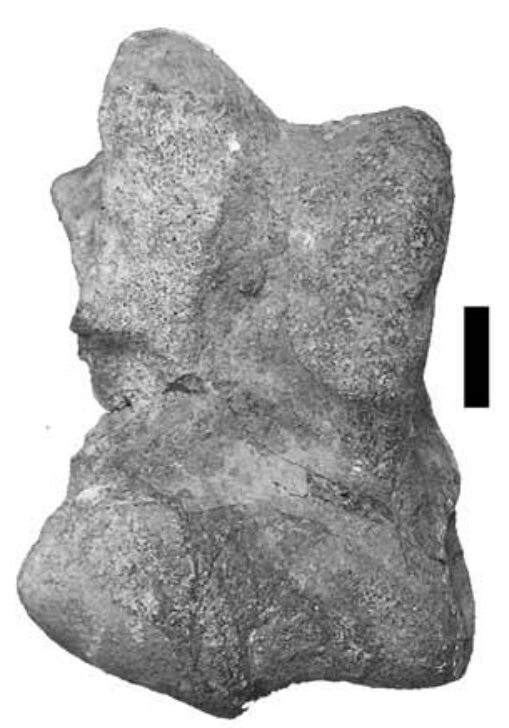

C

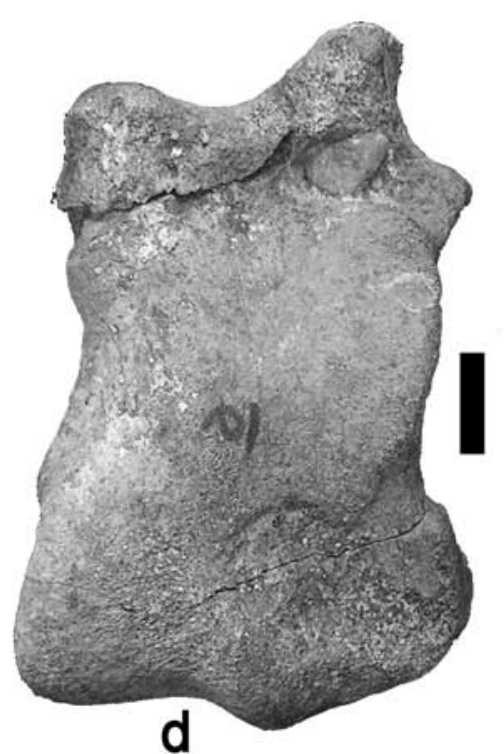

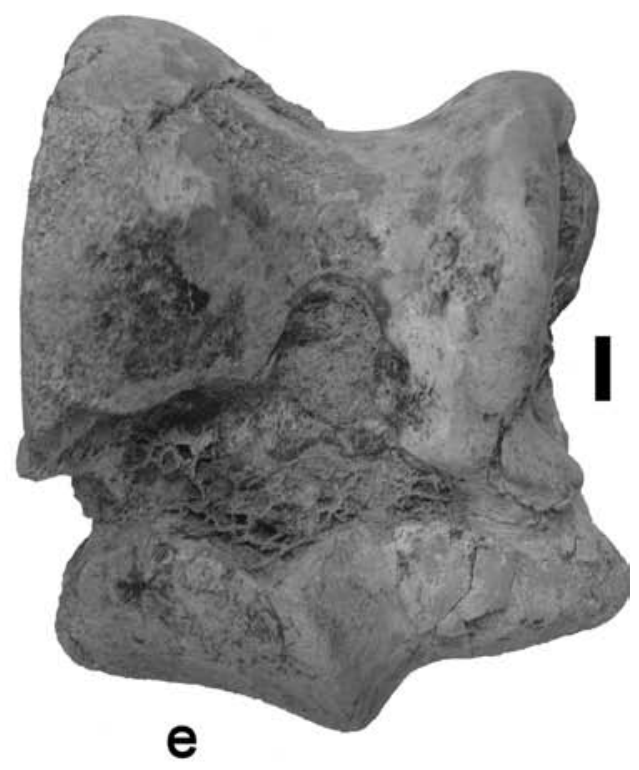

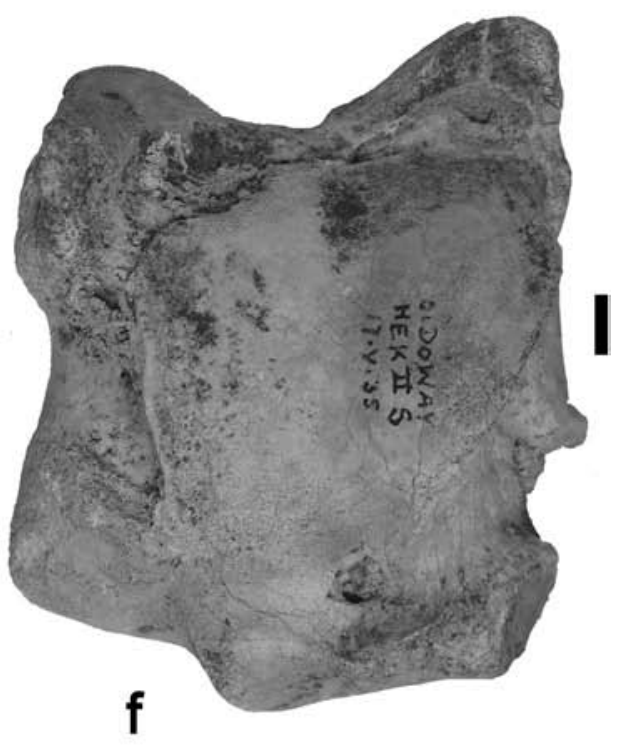

Figure 34. Comparison of tali of (a, b) Merycopotamus dissimilis (Falconer \& Cautley, 1836), left talus from the Upper Siwaliks, India, images reversed; (c, d) Libycosaurus petrocchii Bonarelli, 1947, left talus from Locality 6, Beglia, Tunisia, images reversed and (e, f) Hippopotamus sp. right talus from HEK II, Olduvai, Tanzania (scale: $10 \mathrm{~mm}$ ).

different, with those of anthracotheres being narrow and elongated, somewhat like those of suids, whereas those of hippos are shorter and broader. The angulation of the joint surfaces is different, with hippos having more oblique cuboid and navicular surfaces than those of anthracotheres. In anterior view the angle between the tibial and navicular-cuboid trochleae is more accented in the hippo than in the anthracothere. These differences translate into different rotatory trajectories of the foot relative to the tibia during locomotion, with anthracotheres having their feet oriented slightly beneath the body, whereas hippos have the feet closer to the sagittal plane.

\section{Navicular and cuboid}

The cuboid of Brachyodus aequatorialis possesses two prominent internal, almost horizontal facets for articulation with the navicular, such that in anterior and posterior views, the two bones imbricate with each other for about a quarter of their width. In hippos in contrast the facets are small, often reduced to one small sloping facet, or to two vertically oriented facets, so that when articulated there is little imbrication of the two bones. The latter combination in hippos is closer to that of suids and palaeochoerids than to that of anthracotheres. This translates into 
a more stabilised talar/navicular-cuboid joint in anthracotheres than in hippos.

\section{Metapodials}

The distal ends of the metapodials of palaeochoerids do not have keels on the dorsal surface, unlike those of Tayassuidae and Suidae which do (Fig. 35) (Kowalevsky, 1873, 1874). The Sansan fossils attributed to Choerotherium (now classified in Choeromorus after being called Taucanamo for half a century) illustrated by Kowalevsky (1874, Pl. 7, Fig. 6) show this clearly (confirmed by M. Orliac, pers. comm.). The grouping of Doliochoerus and Palaeochoerus with Tayassuidae and Suidae respectively, by Boisserie et al. (2005b, Fig. 7) is thus inconsistent with the anatomy. It should be noted that the metacarpals of Palaeochoerus illustrated by Kowalevsky (1874, Pl. 7,
Fig. 7) are in fact those of Hyotherium (the same confusion of names occurred with the large skull from St-Gérandle-Puy for a long time identified as Palaeochoerus). This mis-identification has misled researchers for more than 150 years and continues to do so, even though the misattribution was pointed out more than 30 years ago by Ginsburg (1974). Another difference between the metapodes of hippos and anthracotheres concerns the proximo-distal length of the metapodials. In metacarpals and metatarsals which have comparable dimensions of the articular surfaces, the length of the diaphysis is considerably greater in anthracotheres than in hippos.

\section{Summary of post-cranial evidence}

In conclusion, Libycosaurus, which has recently been interpreted to represent the sister-group of hippos (Bois-
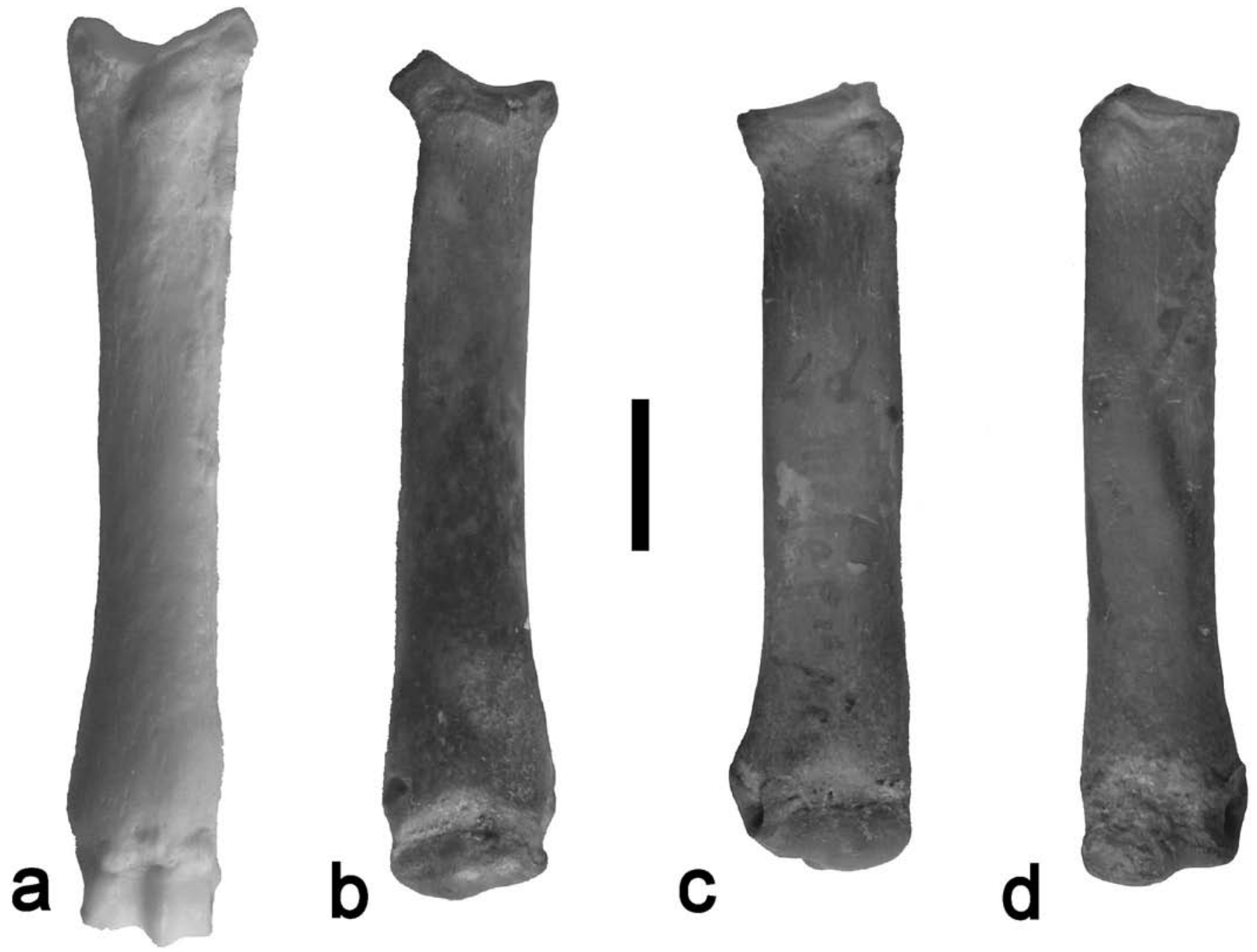

Figure 35. Anterior views of suoid axial metapodials showing presence of anterior keel in the distal epiphysis in tayassuids (a) and the lack of anterior keel in palaeochoerids (b-d); (a) Tayassu pecari (Link, 1795), (b) Choeromorus mammillatum Filhol, 1851, from Sansan, France, (c) and (d) Palaeochoerus typus Pomel, 1847, from St-Gérand-le-Puy, France (scale: 10 mm). 
serie et al., 2005a, Fig. 2) possesses cervical, humeral, femoral, tibial, ankle and metapodial anatomy that does not accord with the scenario of a close phylogenetic relationship between the two (Fig. 36). To this should be added some life history (growth) parameters such as ankylosis of the radio-ulna in hippos, and non-fusion of these bones in Merycopotamus and other anthracotheres. In brief, anthracotheres possessed long limbs, shallow thoracic cag-

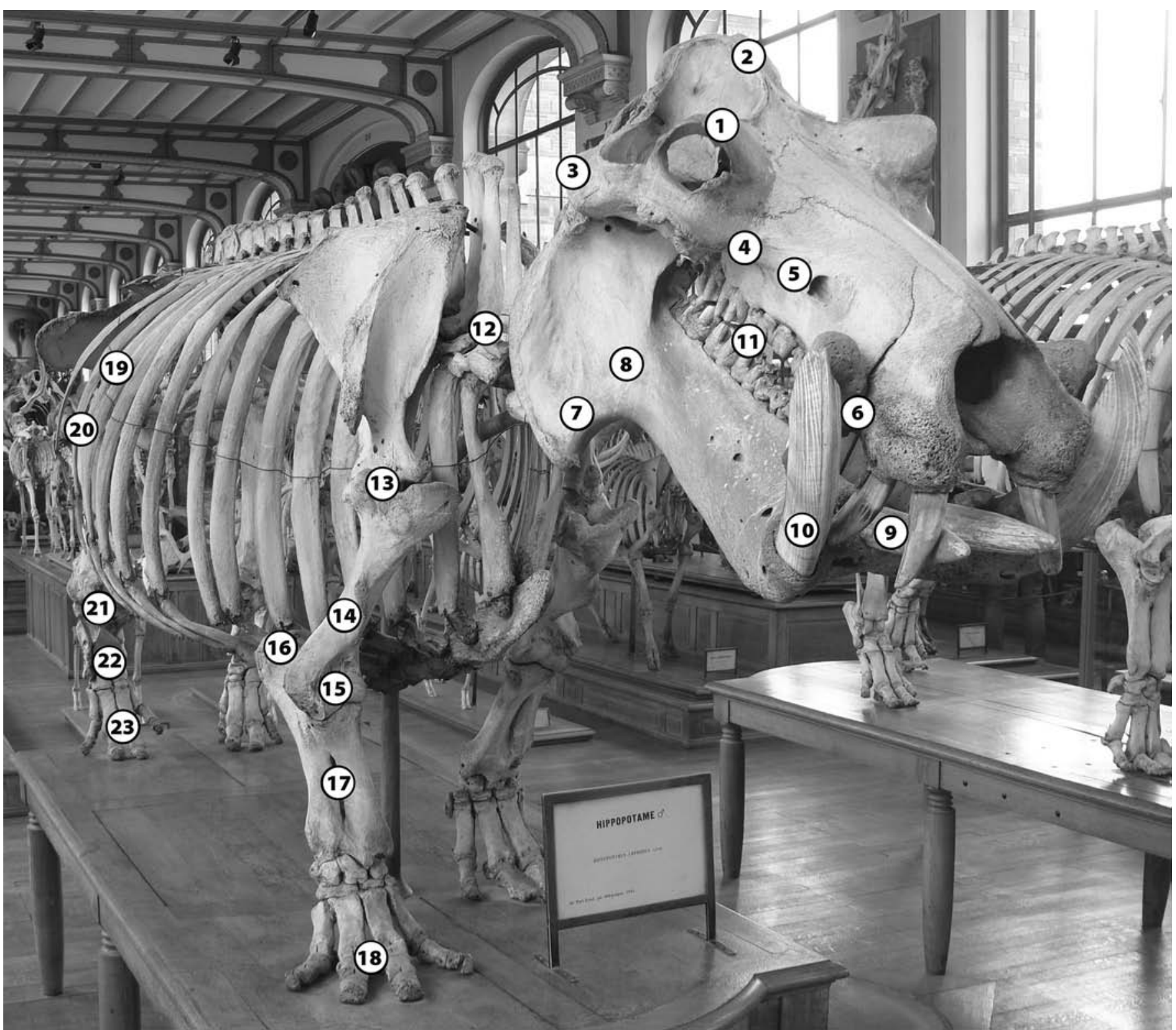

Figure 36. Summary of cranio-dental and skeletal characters discussed in this paper. Characters 1 and 7 (descending plate of mandible and elevated orbits) have been interpreted by several authors as synapomorphies of Libycosaurus Bonarelli, 1947, and Hippopotamus Linnaeus, 1758, but they are not homologous. Characters 1, 3, 4, 5 and 6 represent morphologies which are different in hippos on the one hand, and Merycopotamus Falconer \& Cautley, 1848 ; and Libycosaurus on the other. Characters 9 and 10 (lower incisors and canines) were interpreted by some authors to be apomorphies shared by Libycosaurus petrocchii and Hippopotamus but the description for Libycosaurus is erroneous. The cheek teeth of anthracotheres and hippopotamids (character 10) differ markedly from each other (Libycosaurus even possesses an accessory premolar unique among artiodactyls). Character 19 (pelvis) has been said to link anthracotheres and hippopotamids, but the morphological similarities are possibly due to allometric scaling in large suiforms, and if so are not homologous in the two groups. Character 22 (talus breadth / length ratio) is derived in hippopotamids, but is primitive in anthracotheres, palaeochoerids, suids, sanitheriids and tayassuids. Characters 18 and 23 (absence of anterior keel on distal epiphyses of the axial metapodials and the corresponding morphology of the anterior epiphysis of the 1st phalanges) are plesiomorphic in anthracotheres, palaeochoerids and hippopotamids. In all other post-cranial characters listed, hippos are different from anthracotheres, indicating highly divergent locomotor repertoires. 
es, and long necks (Kowalevsky, 1873; Geais, 1934) (Fig. 37) whereas hippos have short legs, a deep barrel-shaped thoracic cage and a short neck (Blainville, 1846) (Fig. 2). These findings run counter to the observation of Lihoreau (2003) that apart from the talus and metapodials, the postcranial bones of Libycosaurus and Hippopotamus cannot be distinguished from each other.

\section{Scenario of locomotion and habitat of bothriodont anthracotheres}

Taking into account the great development of the supracondyloid fossa of the femur, which houses the attachment of the digital extensors, the subequal dimensions of the trochlear lips, the relatively great depth of the fossa for the femoro-metatarsal ligament, and the lesser inclination of the trochlear groove, it is suggested that these anthracotheres were adapted for a bounding type of locomotion (Fig. 38). The closest analogy that springs to mind regarding the depth and extent of the supracondyloid fossa is that of equids, which also have a large and deep fossa with overhanging walls. Springing and bounding are activities unknown to occur in hippopotamids, which don't even step over low obstacles in their path.

Given that bothriodont remains are almost always found associated with lignites, paludal clays and fluviatile deposits, it is likely that they lived close to or in shallow water bodies. The fact that their limbs are elongated suggests that for most of the time they tended to keep their head and body out of the water, with only the lower limbs submerged (Fig. 38) a completely different strategy from that of hippopotamids, which have short limbs, and habitually keep the body submerged beneath the surface when in deep enough water.

At present there are several artiodactyl species that live preferentially in such settings, deriving not only adequate food resources from the water bodies and their surroundings, but also a certain degree of security from terrestrial predators (Fig. 38). Such species which spend most of their lives in shallow water, are difficult to take by surprise, and when approached by predators, can bound away through the water with much greater ease than carnivores (Fig. 38). In India, the closest analogy to Merycopotamus dissimilis in terms of overall body size and limb proportions is provided by the Sambar [Cervus unicolor (Kerr, 1792)] which spends most of its life in shallow water and the banks close to such water bodies. In South America, an analogous artiodactyl is the Swamp Deer [Blastocerus dichotomus (Illiger, 1815)]. In Africa, the closest analogy to Sivameryx africanus (Andrews, 1914) in terms of body size, is the reduncine bovid, the Lechwe (Kobus leche Gray, 1850) which has similar habitat requirements to the Sambar, but tends to live in large herds. The Sitatunga (Tragelaphus spekei Speke, 1863) is another African antelope that spends most of its time in water, but unlike the Lechwe and the Sambar, it often submerges its body when threatened or surprised, although it too will frequent shallow water bodies in which case its body is emergent.

Smaller anthracotheres, such as Afromeryx zelteni Pickford, 1991, which was about the size of a wild boar [Sus scrofa (Linnaeus, 1758)] but with more elongated legs and feet, may have occupied niches similar to those of the Chinese Water Deer [Hydropotes inermis (Swinhoe, 1870)] and the Water Chevrotain [Hyemoschus aquaticus (Ogilby, 1840)]. These two ruminants live near water bodies in dense forest. They spend much of their time out of the water but when threatened or surprised will plunge into water to escape, often remaining submerged for considerable periods of time during which they breath every few minutes by poking the nostrils up through floating vegetation.

In India, a suitable habitat and ecological analogy for the larger bothriodonts, such as Brachyodus onoideus (Gervais,

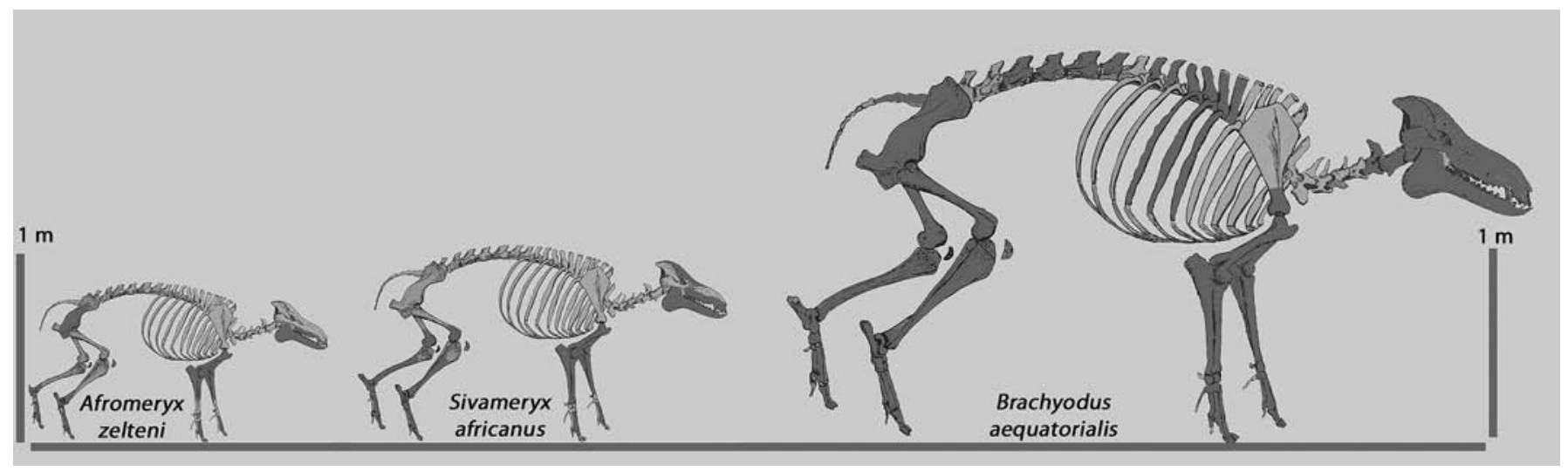

Figure 37. Reconstructions of the skeletons of three species of bothriodont anthracotheres: Afromeryx zelteni Pickford, 1991, Sivameryx africanus (Andrews, 1914), and Brachyodus aequatorialis MacInnes, 1951, based on fossils from Gebel Zelten, Libya, and the Winam Gulf region, Kenya, using the reconstruction of the skeleton of Elomeryx borbonicus Gervais, 1852 , by Geais (1934) as a template. Note the elongated limbs and the humerus emergent beneath the rib cage. 


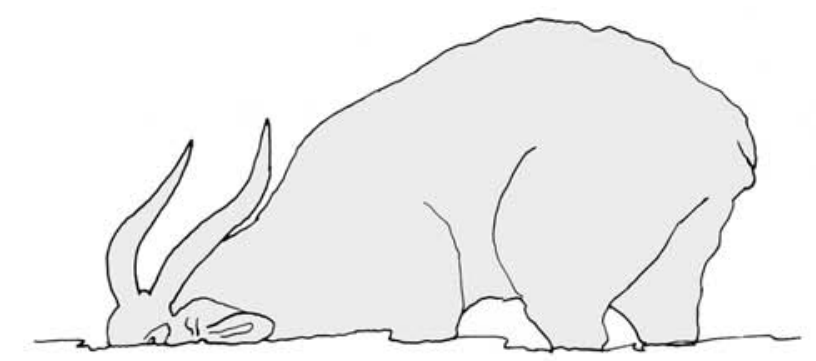

a
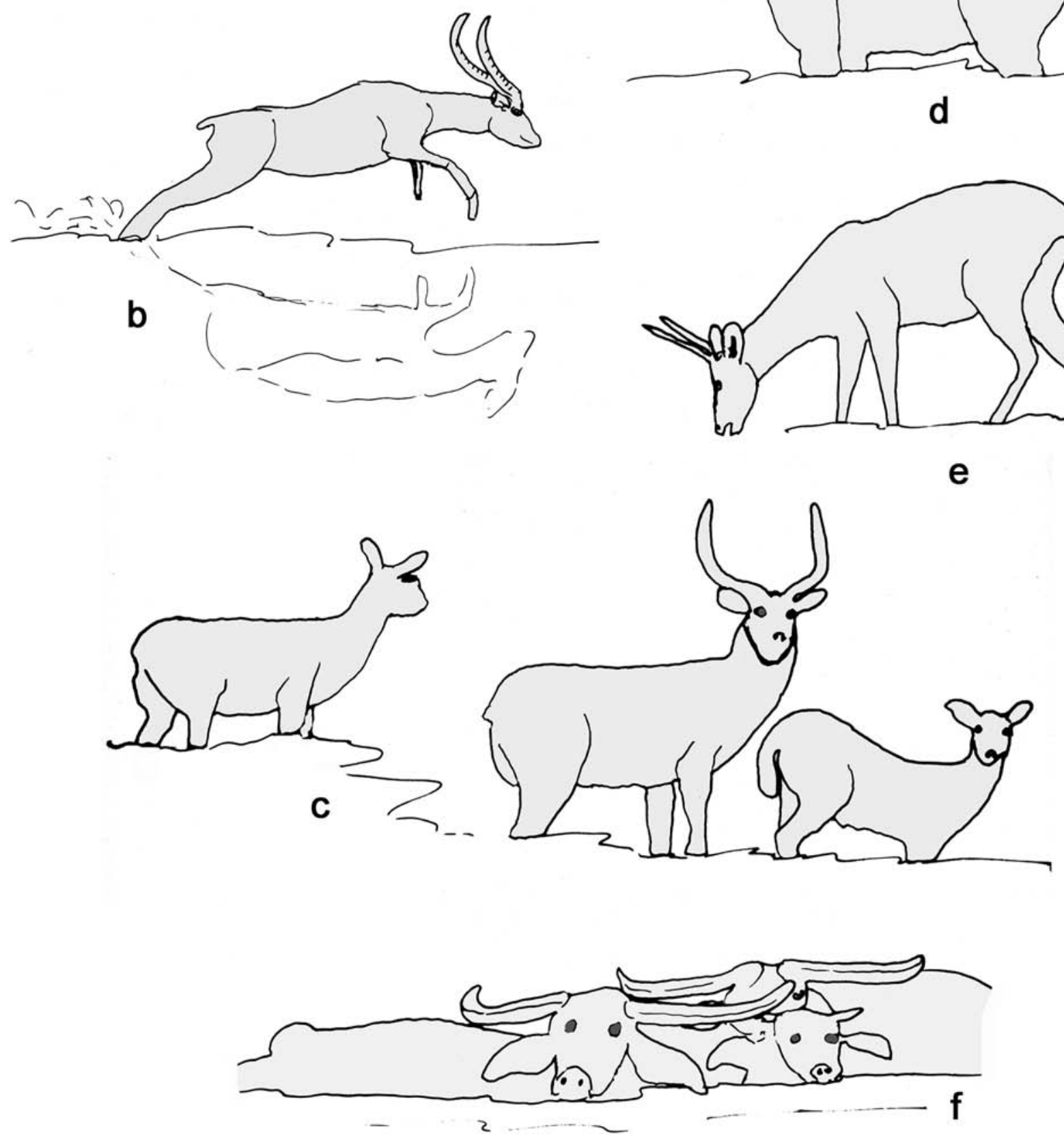

Figure 38. Extant aquaphilous ruminants, (a) Sitatunga (Tragelaphus spekei Speke, 1863) feeding on subaqueous plants in shallow swamp,(b) Lechwe [Kobus leche (Gray, 1850)] male bounding through shallow water (note the splayed front legs, a typical posture adopted during water-bound bounding locomotion), (c) Lechwe (Kobus leche) male and two females in shallow water, (d) Sambar [Cervus unicolor (Kerr, 1792)] male in shallow swamp, (e) Swamp Deer [Blastocerus dichotomus (Illiger, 1815)] in shallow swamp, (f) Water Buffalo (Bubalus bubalis Linnaeus, 1785) mixed herd lying in shallow water. 
1859), which are over a metre tall at the shoulder, is the Water Buffalo (Bubalus bubalis Linnaeus, 1758) which spends much time half submerged in water and mud (Fig. 38).

\section{SUMMARY OF THE DEBATE ABOUT HIPPOPOTAMID ORIGINS}

Table 4 summarises the debate about hippopotamid origins. It is clear that the most contentious hypothesis is the one in which hippos are considered to be derived from anthracotheres, with many proponents for it and an almost equal quantity of contestors against it.

\section{TAPHONOMICAL AND ENVIRONMENTAL CONSIDERATIONS}

Boisserie et al. (2005a, 2005b) suggested that hippos, anthracotheres and whales probably had affinities for

$\begin{array}{lll}\text { Hypothesis } & \text { First mention } & \text { Supported by } \\ \text { 1. Anthracotheriidae } & \text { Falconer \& } & \text { Lydekker, 1876 } \\ & \text { Cautley, 1836 } & \text { Huxley, 1871 } \\ & \text { Colbert, 1935 } \\ & \text { Gentry \& Hooker, 1988 } \\ & \text { Van der Made, 1999 } \\ & \text { Boisserie } \text { et al, 2005a, } \\ & & \text { 2005b Boisserie, 2006 } \\ & & \text { Pearson, 1929 } \\ & \text { Theodor \& Foss, 2006 }\end{array}$

2b Cebochoeridae

Pearson, 1927

Pearson, 1929

3. Suidae (sensu lato)

Matthew, 1934** No-one

4. Tayassuidae (sensu stricto)

Matthew, $1934 \quad$ No-one

5. Palaeochoeridae $* * *$
Pickford, 1983

aquatic environments right from the outset of their evolution 50-60 million years ago (Boisserie et al., 2005a, 2005b). The earliest known Hippopotamidae (Kenyapotaminae) are seldom found in sediments deposited under aquatic conditions (Pickford, 2007). Most have been found in palaeosols, and only the Tunisian material aged ca 12$10 \mathrm{Ma}$ is associated with fluvial deposits, and in contrast to anthracotheres, their fossils are rare therein. Despite the abundance of lacustrine, fluvial and paludal deposits in Africa ranging in age from 23 million to about 8 million years, very few hippo fossils have been found in them. Yet in deposits that accumulated later than 7 million years ago, virtually every African waterlain deposit is replete with hippo remains. The conclusion that I draw is that prior to 7 Ma hippos were not particularly potamophile, certainly not as amphibious as extant hippos, a suggestion that finds support from studies by Harris (1991) and Weston (2003) who showed that even some of the Late Miocene hippopotamines were not as well adapted to aquatic environments as the extant Hippopotamus is. As soon as hippos occupied fluvio-paludal and shallow lacustrine envi-

Theodor \& Foss, 2006

\section{Contested by}

Stehlin, 1899-1900

Pearson, 1929

Matthew, 1929

Pickford, 1983

Theodor \& Foss, 2006

Geisler \& Uhen, 2006

Colbert, 1935

Pickford, 1983

Boisserie et al, 2005a, 2005b

Colbert, 1935

Pickford, 1983

Boisserie et al, 2005a, 2005b

Colbert, 1935
Pickford, 1983

Boisserie et al. 2005a, 2005b

Colbert, 1935

Pickford, 1983

Boisserie et al. 2005a, $2005 b$

Pickford \& Morales, 1989
Boisserie et al. Cranial, dental 2005a, 2005b, but no and postcranial adequate test has been morphology performed

\begin{tabular}{|c|c|}
\hline Evidence for & Evidence against \\
\hline $\begin{array}{l}\text { Descending angle } \\
\text { of mandible, raised } \\
\text { orbits, pelvic } \\
\text { morphology, some } \\
\text { dental features*. }\end{array}$ & $\begin{array}{l}\text { Major differences in } \\
\text { virtually all skeletal and } \\
\text { dental morphology }\end{array}$ \\
\hline $\begin{array}{l}\text { Dental and cranial } \\
\text { features }\end{array}$ & $\begin{array}{l}\text { Some differences in } \\
\text { cranial and dental } \\
\text { morphology }\end{array}$ \\
\hline $\begin{array}{l}\text { Dental and } \\
\text { basicranial features }\end{array}$ & $\begin{array}{l}\text { Some differences in } \\
\text { cranial and dental } \\
\text { morphology }\end{array}$ \\
\hline $\begin{array}{l}\text { General features } \\
\text { of the skull and } \\
\text { dentition }\end{array}$ & $\begin{array}{l}\text { Many differences in th } \\
\text { skull and post-cranial } \\
\text { bones }\end{array}$ \\
\hline $\begin{array}{l}\text { General features of } \\
\text { the skull and teeth }\end{array}$ & $\begin{array}{l}\text { Many differences in } \\
\text { dentition, skull and } \\
\text { post-cranial skeleton }\end{array}$ \\
\hline $\begin{array}{l}\text { Cranial, dental } \\
\text { and postcranial } \\
\text { morphology }\end{array}$ & $\begin{array}{l}\text { Minor differences } \\
\text { in cranial and dental } \\
\text { morphology }\end{array}$ \\
\hline
\end{tabular}

\section{Evidence for} morphology, some 
ronments on a semi-permanent or permanent basis during the Late Miocene, their remains were from then onwards frequently preserved for the simple reason that they were now inhabiting the environments where waterlaid sediments were accumulating, thereby greatly enhancing the chances of their bones being preserved as fossils. Thus, the fossil and taphonomic evidence points to a relatively recent development of obligate potamophily and amphiby in hippos, and certainly not to one dating from the Palaeocene or Eocene. This finding indicates that the few cranial similarities between extant hippos and Libycosaurus noted by Boisserie et al. (2005a, 2005b) are likely to be due to the fact that both were amphibious, rather than to proximity of descent. Neither Saotherium nor Archaeopotamus show the derived amphibious morphology of the cranium that occurs in Hippopotamus and Hexaprotodon among the hippos on the one hand, and the independently derived morphology observed in Libycosaurus and Merycopotamus among the anthracotheres, on the other.

\section{TESTING THE PALAEOCHOERID AND ANTHRACOTHERE HYPOTHESES OF HIPPOPOTAMID ORIGINS}

Because anthracotheres are extinct, molecularists are unable to test the hypothesis of Boisserie et al. (2005a, 2005b) that the anthracotheres represent the phylogenetic link between whales and hippos. It is doubly unfortunate that the proposed sister-group of hippos in the palaeochoerid hypothesis is also extinct, meaning that molecular biologists have no way of testing which one of the hypotheses is more «robust». This means that the only source of information must come from the fossil record. Given the available dental, cranial and post-cranial data, I conclude that the most likely hypothesis of hippo origins is one in which Palaeochoeridae or something close to them played a significant role, leaving the anthracotheres as a more distantly related group of artiodactyls. This does not necessarily mean that anthracotheres were not related to cetaceans, but does imply that if they were, then they went extinct without issue. As this manuscript was nearing completion, work by Theodor \& Foss (2006) and Geisler \& Uhen (2006) was published, suggesting that anthracotheres are not closely related to either whales or hippos. The few resemblances in cranial morphology identified by Boisserie et al. (2005a, 2005b) in support of their hypothesis of sister-group relationships between hippos and anthracotheres are better explained by convergence, hippos eventually coming to inhabit the same kind of environment as anthracotheres, and thus developing weakly comparable cranial osteological adaptations such as raised orbits and high external auditory meatus, but retaining clear dental and post-cranial evidence of their palaeochoerid-like ancestors.

\section{UPDATE OF ASPECTS OF THE PALAEOCHOERID HYPOTHESIS OF HIPPOPOTAMID ORIGINS}

The hypothesis of derivation of the hippopotamids from Palaeochoeridae needs to be updated. A relatively minor change is that I agree that Xenohyus is a suid and should be removed from further consideration in the quest for hippo origins. It sports a pentacone on the M3/, has a tricuspid P4/, and a distal cusplet on the I1/. These features align the material with the genus Hyotherium, a suid, and distance it from palaeochoerids. Hellmund (1992) published a paper on Palaeochoerus and Propalaeochoerus which threw a great deal of light on the cranio-dental anatomy of these suoids, but like many authors before him (Dechaseaux, 1959; Ginsburg, 1974) and some after him (Sudre, 1995) he retained them in Tayassuidae. Van der Made $(1996,1997)$ articulated what had been in the air since Pickford's (1983) paper, that what were being called Old World Tayssuidae, should have a name of their own, the earliest available one for this group being Matthew's (1924) Palaeochoerinae, which Van der Made raised to family rank. But, in contrast to Matthew's concept, which included Miocene American peccaries along with Palaeochoerus in the subfamily, Van der Made excluded New World forms, and restricted it to Old World lineages. I consider this to be essentially correct. The family contains Propalaeochoerus Stehlin, 1899, Palaeochoerus Pomel, 1847, Lorancahyus Pickford \& Morales, 1998, Choeromorus Gervais, 1848 (which used to be called Taucanamo Simpson, 1945, and/or Choerotherium Lartet, 1851), Schizochoerus Crusafont-Pairo \& Lavocat, 1954, Morotochoerus Pickford, 1998, and Yunnanochoerus Van der Made \& Han, 1994 (if the latter is different from Schizochoerus). Doliochoerus Filhol, 1882, possibly belongs to the family, although its tympanic bullae are more inflated than in other genera which preserve evidence of this structure.

Palaeochoerids have no pentacone in the M3/, the P4/ is bicuspid, sometimes with a low disto-buccal cusplet, the I1/ has no distal cusplet, the upper canine jugum is inflated and forms a prominent projecting structure on the surface of the maxilla, the zygomatic process of the maxilla projects laterally, the palatines extend distally well beyond the level of the rear of the M3/, the glenoid surfaces are close to the rear of the skull and have a retro-glenoid process which faces antero-laterally, the sagittal crest is strong but antero-posteriorly short, the splanchnocranium is much longer than the neurocranium. In some taxa, such as Schizochoerus, the upper canine has a distal groove similar to that of Hippopotamus and the upper incisors are permanently growing. In the post-cranial skeleton, the distal epiphysis of the metapodials does not have a ridge, and the abaxial metapodials are long but slender. Whilst many of these characters are probably primitive at the level of 
Suoidea, some such as the ratio of splanchnocranium to neurocranium, clearly projecting canine jugum, and short sagittal crest are probably derived. The combination of characters differentiates the palaeochoerids from the other Suiformes which possess derived morphology for most of these features (Suidae, Anthracotheriidae, Tayassuidae, Sanitheriidae).

A similar combination of features (where preserved in the fossils) also occurs in Palaeopotamus and Kenyapotamus, which both share a number of derived characters with Hippopotamus and Choeropis such as the upper and lower canine morphology (Pickford, 2006) the upper incisor morphology, the trefoliate occlusal outline of the molar cusps and the shortened and broadened talus. Other features are inherited from their ancestral group, including the lack of pentacone on $\mathrm{M} 3 /$, the bicuspid $\mathrm{P} 4 /$ (sometimes with a low distal cusp) and the form of the distal talar trochlea for the navicular and cuboid among others. Finally it should be noted that derivation of hippopotamids from palaeochoerids does not require any reversion of characters, but does imply an increase in body size and some relatively modest changes in dental, cranial and post-cranial morphology.

\section{DISCUSSION}

Whatever the merits or otherwise of the supposed close relationship between hippopotamids and cetaceans based on molecular evidence, it is concluded that hippos are not particularly closely related to anthracotheres but are considerably closer to Palaeochoeridae. Theodor \& Foss (2006) and Geisler \& Uhen (2006) have independently come to the same conclusion that hippos are not closely related to anthracotheres. The former authors found evidence which lends support to the cebochoerid hypothesis of hippo origins on the basis of a study of the deciduous dentition of Eocene cebochoerids, supporting Pearson (1927). The latter authors reported that anthracotheres were more closely related to Suiformes than to hippos or whales.

On the basis of fossils from India, Thewissen et al. (2007) concluded that whales originated from aquatic artiodactyls in the Eocene. The presence of derived cetacean morphology in the raollid Indohyus, including the presence of an involucrum in the auditory bulla, can be interpreted in alternative ways. Thewissen et al. (2007) opted to retain Indohyus in the Artiodactyla, but they pointed out that it could be included in Cetacea. Whatever the case, this interpretation weakens the hypothesis that anthracotheres represent the group that links hippos to whales; not only because the Eocene age of Indohyus makes it as old or older than most anthracotheres, but also because anthracotheres possess auditory bullae with typically artiodactyl morphology (Pearson, 1929). Bothriodont anthracotheres, in particular, are therefore unlikely to represent the missing link between whales and hippos.
As Gatesy \& O’Leary (2001) pointed out, missing data, whether from missing skeletal elements of included taxa, or from missing taxa, can greatly affect the outcome of phylogenetic analyses. In my opinion, characters 10,58 and 61 of Boisserie et al. (2005a) could be scored for Palaeochoerus, yet were missing from their analysis and no postcranial evidence for Palaeochoerus was scored. A major problem with the character scoring of Palaeochoerus by Boisserie et al. (2005a) is that it was based on Pearson's (1927) analysis of a suid skull (Hyotherium) that was misattributed to Palaeochoerus (see Ginsburg, 1974; Van der Made, 1996). Cranial material attributed to Palaeochoerus typus Pomel, 1847, was described by Hellmund (1992) but only one specimen retains part of the basicranium, consisting of the glenoid region. Even though this skull was curated in the Natural History Museum, London, at the time of Pearson's (1927) study, apparently she did not examine it or if she did, then she could not find enough informative evidence in it to include in her study, because the basicranium and much of the otic region is missing.

So can incorrect scoring of characters radically change the outcome of phylogenetic analyses. In the case of $\mathrm{Pal}$ aeochoerus 8 characters $\left(\mathrm{N}^{\circ} \mathrm{s} 8,42,52,60,62,64,65\right.$ and 71) were incorrectly scored by Boisserie et al. (2005a) while most of the neurocranial and basicranial characters that they listed $\left(\mathrm{N}^{\circ}\right.$ s $\left.9,17,24,26,27,36,37,39,40\right)$ are suspect as they do not pertain to Palaeochoerus but to the suid Hyotherium, an error inherited from Pearson's (1927) initial misidentification of the fossils that she examined (Van der Made, 1996). Some of the latter characters may fortuitously be correct, but this cannot be demonstrated on the currently available fossils of Palaeochoerus. The mis-scoring of the proximal extension of the sinovial fossa in tali of Brachyodus also affects the outcome of the analysis.

A serious problem in defining character states is inherent in the wording used to describe morphology. For example, without additional information the words "elevated orbits" imply similar morphology, yet it is known than many unrelated animals possess orbits with the upper margin elevated above the dorsal profile of the skull, including gavialid crocodiles, phacochoerine suids, $\mathrm{Kva}$ bebihyrax Gabunia \& Vekua, 1966 (a late Miocene hyracoid from Georgia), Hippopotamus amphibius, and to a lesser extent Libycosaurus. Whilst elevated orbits in all these animals represent derived morphology within their respective groups, in none of them is the raised orbit homologous. Thus scoring "elevated orbits" in two unrelated animals in the same way in a phylogenetic analysis on the grounds that such a morphology is "derived" will lead to the invalid conclusion that the character is synapomorphic, as was done by Boisserie et al. (2005a, 2005b). Similarly, by scoring hypsorhyzic lower incisors (in hippos) and lower incisors with elongated roots (in Libycosaurus) in the same way, Boisserie et al. (2005a, 2005b) 
imposed synapomorphy on non-comparable morphology. Ditto the descending plate of the mandible in hippos and Merycopotamus. In essence, the problem is one of circularity of argument, similar terminology at the input stage of the analysis emerging as synapomorphies at the output stage, which is then taken to support the phylogeny.

Imperfections of the fossil record are significant in any phylogenetic analysis. In their studies Boisserie et al. (2005a, 2005b) not only omitted characters from included taxa, but they also omitted taxa, including most of the known genera of the family Palaeochoeridae. The fossil record of the latter family is poor when compared to the much better represented Anthracotheriidae, so poor indeed that it was only in 1983 that enough evidence was obtained to indicate that it required removal from Tayassuidae and warranted the creation of its own family, which was formally published in 1996. Even though its fossil record is poor, the fossils attributed to Palaeochoeridae share a number of morphological features with hippopotamids, including dental, cranial, and post-cranial ones. Improvement of their fossil record would be welcome, but even the limited amount of available evidence indicates that it is not necessary to invoke «spectacular reversion» of dental anatomy in order to explain the origin of hippopotamid dentitions, something which is necessary if the hippo ancestor were a bothriodont anthracothere. The few dental characters that were claimed to support the inferences of Boisserie et al. (2005a, 2005b) such as ever-growing canines and prolonged growth of the incisors in anthracotheres are incorrectly reported. Others such as wrinkled and pustular enamel in the premolars are not homologous in the two families. Instead, rather modest changes are all that are required to evolve the hippopotamid dentition from a palaeochoerid precursor.

Boisserie \& Lihoreau (2006) proposed some new scenarios of hippopotamid origins based on their 2005 analyses. These scenarios are compromised for the same reasons that their previous conclusions are.

\section{CONCLUSIONS}

Boisserie et al. (2005a, 2005b) did not refute the palaeochoerid hypothesis of hippo origins -they barely addressed it, as shown by the title of their first publication on the question, which was «Where do hippos come from: anthracotheres or peccaries?» (Lihoreau \& Boisserie, 2004) and the fact that only one palaeochoerid figures in their 2005 paper (Boisserie et al., 2005a). Subsequent publications do not differ fundamentally from this résumé of their initial research programme.

For a scientific hypothesis to be refuted it has to be tested. Needless to say, in a scientific milieu, any tests applied to a hypothesis need to be appropriate. Firstly, Boisserie et al. (2005a, 2005b) appear to have been una- ware of the separate familial status of the Palaeochoeridae, which therefore does not feature as such in their analysis. The family name has been formally applied to the group since 1996, even though the concept of a separate family has been in the literature since at least 1983, albeit under the somewhat confusing name «Old World Tayassuidae». Secondly, the characters included by Boisserie et al. (2005a, 2005b) for the genus Palaeochoerus, which is the type genus of the family Palaeochoeridae, came from skulls and jaws of the suid Hyotherium, which is why, in the phylogenetic tree (Boisserie et al., 2005a, Fig. 2) the genus falls close to Suidae and far from Tayassuidae. Thirdly, the only palaeochoerid in their analysis was Doliochoerus, for which only 62 out of 80 characters were scored (of which three were ambiguous). I disagree with the scoring of four of the dental characters. The postcranial skeleton of palaeochoerids was only represented by the talus (4 characters out of a possible seven) in one genus Doliochoerus.

Because of the absent taxa, missing morphological evidence for the taxa that were included in the analyses, questionable homologies and incorrectly reported morphology of some characters, the conclusions of Boisserie et al. (2005a, 2005b) are unsustainable. They do not represent a valid refutation of the hypothesis of a close relationship between palaeochoerids and hippopotamids. A counter hypothesis of sister-group relationship between anthracotheres and hippopotamids evoked by Boisserie $e t$ al. $(2005 \mathrm{a}, 2005 \mathrm{~b})$ is supported in part by incorrect observations of the morphology of anthracotheres (prolonged or ever-growing incisors and canines for example) but is in large measure due to convergent evolution, hippos and anthracotheres being potamophile and amphibious (cranial features such as elevated orbit and high external auditory meatus for example are due to convergence and are not synapomorphies) or to the retention of primitive morphology (some aspects of the morphology of the talus and metapodials, for instance).

In short, the palaeochoerid ancestry of hippopotamids is not a dead issue. It does not require «spectacular reversions» in dental anatomy (nor for that matter a wholesale reorganisation of morphology of the post-cranial skeleton) a major weakness of the contrasting hypothesis that anthracotheres represent the group from which hippos emerged. In brief, hippopotamids are airorhynch, have the splanchnocranium appreciably longer than the neurocranium, possess bunodont cheek teeth, have short necks, short carpal and tarsal complexes and shortened metapodials, whereas bothriodontine anthracotheres are klinorhynch, have the splanchnocranium about the same length as the neurocranium, possess selenodont cheek dentitions, have long necks, elongated carpal and tarsal complexes and elongated metapodials. These major differences in body plan are accompanied by many detailed differences in the morphology of virtually all the cranial and postcranial bones, 
and in growth variables such as of fusion of the mandibular symphysis and ankylosis of the radio-ulna. In all these features, hippos are closer to palaeochoerids than they are to anthracotheres.

The study of hippopotamid origins highlights the ambiguities that can arise during interpretion of morphological characters, some of which appear at face value to be synapomorphies linking two groups, but which turn out on closer inspection to be due to convergence. In the particular case of hippos and the anthracothere genus Merycopotamus, it is perhaps unprecedented that in the minds of so many researchers, only two superficially similar features (descended mandibular angle, and raised orbits) should have far outweighed in terms of phylogenetic signal, all the manifest differences that occur in the dentition, skull and post-cranial skeleton, thereby spuriously linking together two distinct groups which in reality separated from each other early during the Eocene, if not before. In fact these two supposed synapomorphies arose only during the late Miocene, once in hippos and independently once or perhaps twice in anthracotheres (Merycopotamus which possesses an upward notch in the mandibular base immediately anterior to the descending angle and Libycosaurus which does not). Apart from these two genera no other known anthracothere possesses a deeply descending mandibular angle, be it from the Eocene, Oligocene or Miocene, an observation already made by Lydekker in 1877 .

The complexity of the history of study of hippo-anthracothere relationships is due partly to imperfections of the fossil record, partly to divergence of opinions about the polarity of available morphological features and partly to sample choice and analytical methods used. But the complexity has been exacerbated by incorrect observations of morphology, misidentification of fossils and the tendency for errors to propagate through the literature for extended periods of time. All this history has been played out against the backdrop of a much broader question which has directly or indirectly influenced virtually all researchers, «Are the Artiodactyla monophyletic or paraphyletic ?». The uncertainty appears to be as flagrant today in the molecular age as it was during the decades that followed Darwin's publication on the origins of species. Although it is still not clear whether Artiodactyla are monophyletic or paraphyletic (Thewissen et al., 2007), a degree of consensus is emerging concerning the age of the hippopotamid-anthracothere divergence, with «early divergence» gaining ground over «late divergence» scenarios.

\section{ACKNOWLEDGEMENTS}

I am anxious to acknowledge support from the Collège de France, UMR 5143 of the CNRS, Département Histoire de la Terre du Muséum National d'Histoire Naturelle, the Service Géologique de Tunisie, and the Geological Survey of Namibia. Thanks to
Maeva Orliac for discussions about suiform anatomy and to Jerry Hooker and Andy Currant for access to material in the Natural History Museum, London, and Claire Sagne, for access to fossils in the Muséum National d'Histoire Naturelle, Paris.

\section{LITERATURE CITED}

Andrews, C.W. 1906. A Descriptive Catalogue of the Tertiary Vertebrata of the Fayûm, Egypt. British Museum of Natural History, London, 1-342.

Andrews, C.W. 1914. On the lower Miocene vertebrates from British East Africa, collected by Dr Felix Oswald. Quarterly Journal of the Geological Society of London, 70, 163-186.

Arambourg, C. 1961. Note preliminaire sur quelques vertébrés nouveaux du Burdigalien de Libye. Comptes Rendus Sommaires de la Société géologique de France, 4, 107-108.

Arnason, U., Gullberg, A., Gretasdottir, S., Ursing, B. \& Janke, A. 2000. The mitochondrial genome of the Sperm Whale and a new molecular reference for estimating eutherian divergence dates. Journal of Molecular Evolution, 50, 569-578.

Arnason, U., Gullberg, A. \& Janke, A. 2004. Mitogenic analyses provide new insights into cetacean origin and evolution. Gene, 333, 27-34.

Black, C. 1972. A new species of Merycopotamus (Artiodactyla: Anthracotheriidae) from the late Miocene of Tunisia. Notes du Service géologique de Tunisie, 37, Travaux de géologie Tunisienne, 6, 5-39.

Blainville, H. M. de 1847. Ostéographie et description iconographique des mammifères récents et fossiles. Baillères éditeur, Paris.

Boekschoten, G.J. \& Sondaar, P.Y. 1966. The Pleistocene of the Kathoro Basin (Crete) and its Hippopotamus. Bijdragen tot de Dierkunde, 36, 17-44.

Boekschoten, G.J. \& Sondaar, P.Y. 1972. On the fossil Mammalia of Cyprus I. Proceedings of the Koninklijke Nederlandse Akademie van Wetenschappen, 75, 306-338.

Boisserie, J.-R. 2005. The phylogeny and taxonomy of Hippopotamidae (Mammalia: Artiodactyla): a review based on morphology and cladistic analysis. Zoological Journal of the Linnean Society, 143, 1-26.

Boisserie, J.-R. \& Lihoreau, F. 2006. Emergence of Hippopotamidae: new scenarios. Comptes Rendus Palevol, 5, 749-756.

Boisserie, J.-R., Lihoreau, F. \& Brunet, M. 2005a. The position of Hippopotamidae within Cetartiodactyla. Proceedings of the National Academy of Science, 102, 1537-1541.

Boisserie, J.-R., Lihoreau, F. \& Brunet, M. 2005b. Origins of Hippopotamidae (Mammalia, Cetartiodactyla): towards resolution. Zoologica Scripta, 34, 119-143.

Bonarelli, G. 1947. Dinosauro fossile del Sahara Cirenaico. Rivista di Biologia Coloniale, Roma, 8, 23-33.

Bouvrain, G. \& De Bonis, L. 1999. Suoidea du Miocène inférieur de Laugnac (Lot-et-Garonne, France). Paläontologische Zeitschrift, 73, 167-178. 
Colbert, E.H. 1935. The phylogeny of the Indian Suidae and the origin of the Hippopotamidae. American Museum Novitates, 799, 1-24.

Cope, E.D. 1879. Second contribution to a knowledge of the Miocene fauna of Oregon. Proceedings of the American Philosophical Society, 18, 370-376.

Cope, E.D. 1882. Scientific news. American Naturalist, 16, 1029.

Cope, E.D. 1888. On the Dicotylinae of the John Day Miocene of North America. Proceedings of the American Philosophical Society, 25, 62-79.

Coryndon, S.C. 1976. Fossil Hippopotamidae from PlioPleistocene successions of the Rudolf Basin. In: Earliest Man and Environments in the Lake Rudolf Basin (Eds. Y. Coppens, F. Howell, G. Isaac \& R. Leakey). Chicago University Press, 238-250.

Coryndon, S.C. 1977. The taxonomy and nomenclature of the Hippopotamidae (Mammalia, Artiodactyla) and a description of two new fossil species. Proceedings of the Koninklijke Nederlandse Akademie van Wetenschappen, B.80 (2), 61-88.

Coryndon, S.C. 1978a. Hippopotamidae. In: Evolution of African Mammals (Eds. V.J. Maglio \& H.B.S. Cooke). Harvard University Press, Cambridge, 284-395.

Coryndon, S.C. 1978b. Fossil Hippopotamidae from the Baringo Basin and relationships within the Gregory Rift, Kenya. In: Geological Background to Fossil Man (Ed. W.W. Bishop). Scottish Academic Press, Edinburgh, 279-292.

Crusafont-Pairo, M. 1979. Les Giraffidés des gisements du Bled Douarah (W. de Gafsa) Tunisie. Notes du Service géologique de Tunisie, 44, 5-73.

Crusafont-Pairo, M., \& Lavocat, R. 1954. Schizochoerus un nuevo género de Suidos del Pontiense inferior (Vallesiense) del Valles Penedes. Notas y Communicaciones del Instituto Geologico y Minero de España, 36, 79-90.

Cuvier, G. 1804. Sur l'Hippopotame et sur son osteologie. Annales du Museum National d'Histoire Naturelle, Paris, 4, 299-328.

Cuvier, G. 1822. Recherches sur les ossements fossiles. $2^{\mathrm{ème}}$ Edition. E. d'Ocagne, Paris.

Dechaseaux, C. 1959. Le Genre Doliochoerus. Annales de Paléontologie, 54, 3-16.

Dehm, R. \& Oettingen-Spielberg, T. 1958. Paläontologische und geologische Untersuchungen im Tertiär von Pakistan. 2. Die mitteleocänen Säugetiere von Ganda Kas bei Basal in Nordwest-Pakistan. Bayerische Akademie der Wissenschaften, Abhandlungen, Klasse für Mathematik, Physik und Technik, 81, 1-54.

de Jong, W. 1998. Molecules remodel the mammalian tree. TREE, 13 (7), 271-275.

Depéret, C. 1895. Über die Fauna von miocänen Wirbelthieren aus der ersten Mediterranstufe von Eggenburg. Sitzsungsberichte der Mathematisch-Naturwissen schaftlichen Classe der kaiserlichen Akademie der Wissenschaften in Wien, 104, 1-22.

Depéret, C. 1921. La phylogenie des Hippopotames. Bulletin de la Société Géologique de France, $4^{\text {ème }}$ ser., 21, 163165 .
Dietrich, W.O. 1928. Pleistocäne deutschostafrikanische Hippopotamus-reste. Wissenschaften der Ergebnisse der Oldoway-Expedition, 1913, N.S. 3, 1-41.

Dineur, H. 1981. Le genre Brachyodus, Anthracotheriidae (Artiodactyla, Mammalia) du Miocène inférieur d'Europe et d'Afrique. Mémoires des Sciences de la Terre, Université Paris VI. Thèse 3ème Cycle, 1-180.

Falconer, H. 1868. Fauna Antiqua Sivalensis: Description of Plates. Smith, Elder \& Co, London.

Falconer, H. \& Cautley, P.T. 1836. Note on the fossil $\mathrm{Hi}$ ppopotamus of the Siwalik Hills. Asiatic Researches, 19, 39-53.

Falconer, H. \& Cautley, P.T. 1848. Fauna Antiqua Sivalensis, Plates. Smith, Elder \& Co, London.

Filhol, H. 1882. Observations relatives à un nouveau genre de Mammifères allié à la famille des Suidés. Comptes Rendus de l'Académie des Sciences de Paris, 1882, 1258.

Fischer von Waldheim, G., 1814. Zoognosia, Tabulis synopticis illustrata, Nikolai Sergedis Vsevolozky, Moscow, 3 volumes, 3-1814.

Forster-Cooper, C. 1915. New genera and species of mammals from the Miocene deposits of Baluchistan. Annals and Magazine of Natural History, 16, 404-409.

Forsyth Major, C. 1902. Some account of a nearly complete skeleton of Hippopotamus madagascariensis, Guldb., from Sirabé, Madagascar, obtained in 1895. Geological Magazine, 9, 192-199.

Fourtau, R. 1918. Contributions à l'étude des vertébrés miocènes de l'Egypte, Ministry of Finance Egypt Survey Department, i-vii+1-121.

Frechkop, S. 1955. Sous-ordre des Suiformes. In: Traité de Zoologie (Ed. P. Grassé). Masson et Cie, Paris, 17 (1), 509-535.

Gabunia, L., \& Vekua, A.K. 1966. An unusual member of the Hyracoidea from the upper Pliocene of Eastern Georgia. Akademii Nauk Gruzinskoy SSR Soobsch'eniya, 42 (3), 645-647.

Gatesy, J. 1997. More DNA support for a Cetacea/Hippopotamidae clade: the blood-clotting protein gene y-fibrinogen. Molecular Biology and Evolution, 14, 537-543.

Gatesy, J. 1998. Molecular evidence for the phylogenetic affinities of Cetacea. In: The Emergence of Whales (Ed. J.G.M. Thewissen). Plenum Press, New York, 63-111.

Gatesy, J., Hayashi, C., Cronin, M.A. \& Arctander, P. 1996. Evidence from milk casein genes that cetaceans are close relatives of hippopotamid artiodactyls. Molecular Biology and Evolution, 13, 954-963.

Gatesy, J., Milinkovitch, L., Waddell, V. \& Stanhope, M. 1999. Stability of cladistic relationships between Cetacea and higher-level artiodactyl taxa. Systematic Biology, 48, 6-20.

Gatesy, J. \& O'Leary, M. 2001. Deciphering whale origins with molecules and fossils. TREE, 16, 562-570.

Gaziry, A.W. 1982. Anthracotheriidae and Hippopotamidae from the Sahabi Formation. Garyounis Science Bulletin, Special Issue, 4, 63-70.

Gaziry, A.W. 1987a. Merycopotamus petrocchii (Artiodactyla, Mammalia) from Sahabi, Libya. In: Neogene Paleontology 
and Geology of Sahabi (Eds. N. Boaz et al.) Alan Liss, New York, 287-302.

Gaziry, A.W. 1987b. Hexaprotodon sahabiensis (Artiodactyla, Mammalia) a new Hippopotamus from Libya. In: Neogene Paleontology and Geology of Sahabi (Eds. N. Boaz et al.) Alan Liss, New York, 303-315.

Geais, G. 1934. Le Brachyodus borbonicus des Argiles de StHenri (près Marseille). Travaux du Laboratoire de Géologie du Faculté des Sciences, Lyon, 25 (Mém. 21), 3-54.

Geisler, J.H. 2001. New morphological evidence for the phylogeny of Artiodactyla, Cetacea and Mesonychidae. American Museum Novitates, 40, 1-53.

Geisler, J.H. \& Luo, Z. 1998. Relationships of Cetacea to terrestrial ungulates and the evolution of cranial vasculature in Cete. In: The Emergence of Whales (Ed. J.G.M. Thewissen). Plenum Press, New York, 163-212.

Geisler, J.H. \& O'Leary, M. 1997. A phylogeny of Cetacea, Artiodactyla, Perissodactyla, and archaic ungulates: the morphological evidence. Journal of Vertebrate Paleontology, 17, 48A.

Geisler, J.H. \& Uhen, M.D. 2003. Morphological support for a close relationship between hippos and whales. Journal of Vertebrate Paleontology, 23, 991-996.

Geisler, J.H. \& Uhen, M.D. 2006. Phylogenetic relationships of extinct cetartiodactyls: Results of simultaneous analyses of molecular, morphological, and stratigraphic data. Journal of Mammalian Evolution, 12, 145-160.

Gentry, A. \& Hooker, J. 1988. The phylogeny of the Artiodactyla. In: The Phylogeny and Classification of the Tetrapods Vol. 2 Mammals (Ed. M.J. Benton). Clarendon Press, Oxford, 235-272.

Gervais, P. 1848. Zoologie et Paléontologie françaises (animaux vertébrés) ou nouvelles recherches sur les animaux vivants et fossiles de la France. Paris, Bertrand, volume 1.

Gervais, P. 1852. Zoologie et Paléontologie françaises (animaux vertébrés) ou nouvelles recherches sur les animaux vivants et fossiles de la France. Paris, Bertrand, volume 3.

Gervais, P. 1859. Zoologie et Paléontologie françaises (animaux vertébrés). Nouvelles recherches sur les animaux vertébrés dont on trouve les ossements enfouis dans le sol de la France et sur leur comparaison avec les espèces propres aux autres régions du globe. Paris, Arthus Bertrand, 1 volume and 1 atlas.

Gingerich, P.D., Haq, M., Zalmout, I.S., Hussain, K.I. \& Malkani, M.S. 2001. Origin of whales from early artiodactyls: hands and feet of Eocene Protocetidae from Pakistan. Science, 293, 2239-2242.

Gingerich, P. \& Uhen, M. 1998. Likelihood estimation of the time of origin of Cetacea and the time of divergence of Cetacea and Artiodactyla. Palaeontologica electronica, 1, 1-47.

Ginsburg, L. 1974. Les Tayassuidés des Phosphorites du Quercy. Palaeovertebrata, 6, 55-85.

Ginsburg, L. 1980. Xenohyus venitor, suidé nouveau (Mammalia, Artiodactyla) du Miocène inférieur de France. Geobios, 13, 861-877.
Ginsburg, L., Huin, J. \& Locher, J.-P. 1988. Les Suidae (Artiodactyla, Mammalia) du Miocène inférieur des Beilleaux à Savigné-sur-Lathal (Indre-et-Loire). Bulletin du Muséum National d'Histoire Naturelle, 20, 197-207.

Grauer, D. \& Higgins, D.G. 1994. Molecular evidence for the inclusion of cetaceans within the order Artiodactyla. Molecular Biology and Evolution, 11, 357-364.

Gray, J.E. 1850. Preface. In: Gleanings from the Menagerie and Aviary at Knowsley Hall, Volume 2, Hoofed Quadrupeds, Knowsley, Printed for Private Distribution, p. 23.

Gray, J.E. 1854. On the painted pig of the Cameroons (Potamochoerus penicillatus). Proceedings of the Zoological Society of London, 1852, 129-131.

Gray, J.E. 1868. Synopsis of the species of pigs (Suidae) in the British Museum. Proceedings of the Zoological Society of London, 1868, 17-49.

Guldberg, G.A. 1883. Undersøgelser over en subfossil Flodhest fra Madagaskar. Forhandlinger $i$ Videnskabsselskabet i Kristiana, 6, 1-24.

Harris, J.M. 1991. Family Hippopotamidae. In: Koobi Fora Research Project 3. The Fossil Ungulates: Geology, Fossil Artiodactyls and Palaeoenvironments (Ed. J.M. Harris). Clarendon Press, Oxford, 31-85.

Harrison, T. 1997. The anatomy, paleobiology, and the phylogenetic relationships of the Hippopotamidae (Mammalia, Artiodactyla) from the Manonga Valley, Tanzania. In: Neogene Paleontology of the Manonga Valley, Tanzania (Ed. T. Harrison). Topics in Geobiology, 14, New York, Plenum Press, 137-190,

Hasegawa, M. \& Adachi, J. 1996. Phylogenetic position of cetaceans relative to artiodactyls: Reanalysis of mitochondrial and nuclear sequences. Molecular Biology and Evolution, 13, 710-717.

Hasegawa, M., Adachi, J. \& Milinkovitch, M.C. 1997. Novel phylogeny of whales supported by total molecular evidence. Journal of Molecular Evolution, 44 (Suppl. 1), S117-S120.

Hellmund, M. 1992. Schweinartige (Suina, Artiodactyla, Mammalia) aus oligo-miozänen Fundstellen Deutschlands, der Schweiz und Frankreichs II. Revision von Palaeochoerus Pomel, 1847 und Propalaeochoerus Stehlin 1899 (Tayassuidae). Stuttgarter Beiträge zur Naturkunde, Serie $B$ (Geologie und Paläontologie), 189, 1-75.

Hodgson, B.H. 1847. On various genera of the ruminants. Journal of the Asiatic Society of Bengal, 16, 685-711.

Houtekamer, J.L. \& Sondaar, P.Y. 1979. Osteology of the forelimb of the Pleistocene Dwarf Hippopotamus from Cyprus with special reference to phylogeny and function. Proceedings of the Koninklijke Nederlandse Akademie van Wetenschappen, B.82, 411-448.

Huxley, T. 1871. Anatomy of Vertebrated Animals, Churchill, London, $431 \mathrm{pp}$.

Illiger, J.K.W. 1815. Überblick der Säugethiere nach ihrer Vertheilung über die Welttheile. Abhandlungen der Physikalischen Klasse der Königlich-Preussischen Akademie der Wissenschaften aus den Jahren 1804-1811, 39-159.

Joleaud, L. 1920. Contribution à l'étude des Hippopotames fossiles. Bulletin de la Société Géologique de France, $4^{\text {ème }}$ ser., 20, 13-26. 
Kerr, R., 1792. Animal Kingdom or Zoological System of the Celebrated Sir Charles Linnaeus; Class I. Mammalia ... London, J. Murray \& R. Faulder, Volume 1, 400 pp.

Kleineidam, R., Pesole, G., Breukelman, H., Beintema, J. \& Kasrelein, R. 1999. Inclusion of cetaceans within the Order Artiodactyla based on phylogenetic analyses of pancreatic ribonuclease genes. Journal of Molecular Evolution, 48, 360-368.

Kowalevsky, W. 1873. On the osteology of the Hyopotamidae. Philosophical Transactions of the Royal Society of London, 39, 1-94.

Kowalevsky, W. 1874. Monographie der Gattung Anthracotherium Cuv. und Versuch einer natürlich Classification der fossilen Hufthiere. Palaeontographica, 22, 133-346.

Langer, P. 2001. Evidence from the digestive tract on phylogenetic relationships in ungulates and whales. Journal of Zoological Systematics and Evolutionary Research, 39, 77-90.

Lartet, E. 1851. Notice sur la colline de Sansan, suivi d'une récapitulation des diverses espèces d'animaux vertébrés fossiles, trouvés, soit à Sansan, soit dans d'autres gisements de terrain Tertiaire miocènes dans le bassin souspyrénéen, Auch.

Lavocat, R. 1955. Sous-ordre des Suiformes. In: Traité de Zoologie (Ed. P. Grassé). Masson et Cie, Paris, 17 (1), 536-551.

Laws, R.M. 1968. Dentition and ageing of the Hippopotamus. East African Wildlife Journal, 6, 19-52.

Leakey, L.S.B. 1966. Tertiary fossil mammals (discussion). In: African Ecology and Human Evolution (Eds. F.C. Howell \& F. Bourlière). Aldine, Chicago, 553-554.

Leidy, J. 1850. Observations on two new genera of fossil Mammalia, Eucrotophus jacksoni, and Archaeotherium mortoni. Proceedings of the National Academy of Sciences of Philadelphia, 5, 90-93.

Leidy, J. 1853. A memoir on the extinct Dicotylinae of America. Transactions of the American Philosophical Society, 10, 323-343.

Leidy, J. 1869. The extinct mammalian fauna of Dakota and Nebraska, including an account of some allied forms from other localities, together with a synopsis of the mammalian remains of North America. Journal of the Academy of Natural Science of Philadelphia, 2, 1-427.

Lihoreau, F. 2003. Systématique et Paléoécologie des Anthracotheriidae (Artiodactyla: Suiformes) du Mio-Pliocène de l'Ancien Monde: implications Paléobiogéographiques. Thèse, University of Poitiers, 395 pp.

Lihoreau, F. \& Boisserie, J.-R. 2004. Where do hippos come from: anthracotheres or peccaries? Journal of Vertebrate Paleontology, 24 (supplement), 83A.

Link, H.F. 1795. Über die Lebenskrafte in naturhistorischer Rücksicht und die Classification der Saugethiere, Beytrage zur Naturgeschichte, Rostock, 2, 104.

Linnaeus, C. 1758. Systema Natura, $10^{\text {th }}$ Edition.

Luckett, P. \& Hong, N. 1998. Phylogenetic relationships between the orders Artiodactyla and Cetacea: a combined assessment of morphological and molecular evidence. Journal of Mammalian Evolution, 5, 127-182.
Lydekker, R. 1876. Notes on the osteology of Merycopotamus dissimilis. Records of the Geological Survey of India, 9, 144-153.

Lydekker, R. 1877. Notices of new and rare mammals from the Siwaliks. Records of the Geological Survey of India, 10, 76-83.

Lydekker, R. 1883. Indian Tertiary and Post-Tertiary Vertebrata: Siwalik Selenodont Suina. Palaeontologica indica, 10, 143-177.

Lydekker, R., 1885. Catalogue of the Fossil Mammalia in the British Museum, Part 2. Taylor \& Francis, London, 323 pp.

Lydekker, R. 1886. Indian Tertiary and Post-Tertiary Vertebrata: Siwalik Mammalia - Supplement 1. Palaeontologica indica, 4, 16-18, Pl. 5, 6.

MacInnes, D.G. 1951. Miocene Anthracotheriidae from East Africa. Fossil Mammals of Africa, 4, 1-24.

Marsh, O.C. 1875. Notice of new Tertiary mammals, IV. American Journal of Science, 3, 239-250.

Matthew, W.D. 1907. A lower Miocene fauna from South Dakota. Bulletin of the American Museum of Natural History, 23, 169-219.

Matthew, W.D. 1924. Third contribution to the Snake Creek fauna. Bulletin of the American Museum of Natural History, 50, 59-210.

Matthew, W.D. 1929a. Reclassification of the artiodactyl families. Bulletin of the Geological Society of America, 40, 403-408.

Matthew, W.D. 1929b. Critical observations upon Siwalik Mammals. Bulletin of the American Museum of Natural History, 56, 437-560.

Matthew, W.D. 1934. A phylogenetic chart of the Artiodactyla. Journal of Mammalogy, 15, 207-209.

Meisner, A., Klaus, A. \& O’Leary, M. 2005. Sperm head morphology in 36 species of Artiodactylans, Perissodactylans and Cetaceans (Mammalia). Journal of Morphology, 263, 179-202.

Milinkovitch, M.C., Bérubé, C. \& Palsboll, P. 1998. Cetaceans are highly derived artiodactyls. In: The Emergence of Whales (Ed. J.G.M. Thewissen). Plenum Press, New York, 113-131.

Milinkovitch, M.C. \& Thewissen, J.G.M. 1997. Even-toed fingerprints on whale ancestry. Nature, 388, 622-624.

Miyamoto, M. 1999. Molecular systematics: Perfect SINEs of evolutionary history? Current Biology, 9, 816-819.

Montgelard, C., Catzeflis, F.M. \& Douzery, E. 1997a. Phylogenetic relationships of artiodactyls and cetaceans as deduced from the comparison of cytochrome $\mathrm{b}$ and $12 \mathrm{~s}$ rRNA mitochondrial sequences. Molecular Biology and Evolution, 14, 550-559.

Montgelard, C., Ducrocq, S. \& Douzery, E. 1997b. What is a suiforme (Artiodactyla)? Contribution of cranioskeletal and mitochondrial DNA data. Molecular Phylogenetics and Evolution, 9, 528-532.

Morton, S.G. 1849. Additional observations on a new living species of hippopotamus. Journal of the National Academy of Sciences of Philadelphia, 1 (4), 231-239.

Nakaya, H., Pickford, M., Yasui, K. \& Nakano, Y. 1987. Additional large mammalian fauna from the Namurungule 
Formation, Samburu Hills, Northern Kenya. African Study Monographs, Supplementary Issue, 5, 79-130.

Naylor, G. \& Adams, D.C. 2001. Are the fossil data really at odds with the molecular data? Morphological evidence for Cetartiodactyla phylogeny reexamined. Systematic Biology, 50, 444-453.

Naylor, G. \& Adams, D.C. 2003. Total evidence versus relevant evidence: a response O'Leary et al. (2003). Systematic Biology, 52, 864-865.

Nikaido, M., Rooney, A.P. \& Okada, N. 1999. Phylogenetic relationships among cetartiodactyls based on insertions of short and long interspersed elements: hippopotamuses are the closest extant relatives of whales. Proceedings of the National Academy of Sciences of the United States of America, 96, 10261-10266.

Nomura, O. \& Yasue, H. 1999. Phylogenetic relationships among hippopotamus, whales, and bovine based on SINE insertion analysis. Mammalian Genome, 10, 526-527.

Nomura, O., Lin, Z-H., Muladno, Wada, Y. \& Yasue, H. 1998. A SINE species from Hippopotamus and its distribution among animal species. Mammalian Genome, 9, 550-555.

Ogilby, W. 1840. Proceedings of the Zoological Society of London, 8 (88 \& 89), 35.

O'Leary, M. 1998. Phylogenetic and morphometric reassessment of the dental evidence for a mesonychian and cetacean clade. In: The Emergence of Whales (Ed. J.G.M. Thewissen). Plenum Press, New York, 133-161.

O'Leary, M. 1999. Parsimony analysis of total evidence from extinct and extant taxa and the cetacean - artiodactyl question (Mammalia, Ungulata). Cladistics, 15, 315-330.

O'Leary, M. 2001. The phylogenetic position of cetaceans: further combined data analyses, comparisons with the stratigraphic record and a discussion of character optimization. American Zoologist, 41, 487-506.

O’Leary, M. \& Geisler, J.H. 1999. The position of Cetacea within Mammalia: phylogenetic analysis of morphological data from extinct and extant taxa. Systematic Biology, 48, 455-490.

O'Leary, M., Geisler, J.H. \& Novacek, M. 2003. Are the dental data really at odds with the molecular data? Morphological evidence for Whale phylogeny $(\mathrm{Re})$ Reexamined. Systematic Biology, 52, 853-864.

O'Leary, M. \& Uhen, M.D. 1999. The time of origin of whales and the role of behavioral changes in the terrestrialaquatic transition. Paleobiology, 25, 534-556.

Owen, R. 1845. Odontography. London, H. Bailliere, 655 pp.

Palmer, T.S. 1897. Notes on the nomenclature of four genera of tropical American mammals. Proceedings of the Biological Society of Washington, 11, 173-174.

Pearson, H.S. 1927. On the skulls of early Tertiary Suidae together with an account of the otic region in some other primitive Artiodactyla. Philosophical Transactions of the Royal Society of London, B215, 389-460.

Pearson, H.S. 1929. The hinder end of the skull in Merycopotamus and in Hippopotamus minutus. Journal of Anatomy, 63, 237-241.
Pickford, M. 1983. On the origins of the Hippopotamidae together with a description of two new species, a new genus and a new subfamily from the Miocene of Kenya. Geobios, 16, 193-217.

Pickford, M. 1989. Update on hippo origins. Comptes Rendus de l'Académie des Sciences, Paris, 309, 163-168.

Pickford, M. 1990. The discovery of Kenyapotamus in Tunisia. Annales de Paléontologie, 76, 277-283.

Pickford, M. 1991. Revision of the Neogene Anthracotheriidae of Africa. In: The Geology of Libya (Ed. M.J. Salem). Elsevier, Amsterdam, 4, 1491-1525.

Pickford, M. 1993. Old World Suoid systematics, phylogeny, biogeography and biostratigraphy. Paleontologia i Evolucio, 26-27, 237-269.

Pickford, M. 1998. A new genus of Tayassuidae (Mammalia) from the middle Miocene of Uganda and Kenya. Annales de Paléontologie, 84, 275-285.

Pickford, M. 2001. Afrochoerodon nov. gen. kisumuensis (MacInnes) (Proboscidea, Mammalia) from Cheparawa, Middle Miocene, Kenya. Annales de Paléontologie, 87, 99-117.

Pickford, M. 2003. Early and Middle Miocene Anthracotheriidae (Mammalia, Artiodactyla) from the Sperrgebiet, Namibia. Memoirs of the Geological Survey of Namibia, 19, 283-290.

Pickford, M. 2006. Sexual and individual morphometric variation in Libycosaurus (Mammalia, Anthracotheriidae) from the Maghreb and Libya. Geobios, 39, 267-310.

Pickford, M. 2007. Suidae and Hippopotamidae from the Middle Miocene of Kipsaraman, Kenya, and other sites in East Africa. Paleontological Research, 11, 85-105.

Pickford, M., 2008. Libycosaurus petrocchii Bonarelli, 1947, and Libycosaurus anisae (Black, 1972) (Anthracotheriidae, Mammalia): nomenclatural and geochronological implications. Annales de Paléontologie, 94, 39-55.

Pickford, M. (in press). The anterior dentition of Libycosaurus anisae and Kenyapotamus coryndoni from Beglia, Tunisia: implications for the affinities of anthracotheres and hippopotamids. Notes du Service Géologique de Tunisie (in press).

Pickford, M. \& Morales, J. 1989. On the tayassuid affinities of Xenohyus, Ginsburg, 1980, and the description of new fossils from Spain. Estudios Geológicos, 45, 233-237.

Pickford, M., \& Morales, J. 1998. A tubulidentate suiform lineage (Tayassuidae, Mammalia) from the early Miocene of Spain. Comptes Rendus de l'Académie des Sciences de Paris, 327, 285-290.

Pilgrim, G.E. 1925. Presidential address to the geological section of the 12th Indian Science Congress. Proceedings of the 12th Indian Science Congress, 200-218.

Pomel, A. 1847. Note sur des animaux fossiles découvertes dans le département de l'Allier. Bulletin de la Société Géologique de France, $2^{\text {ème }}$ ser., 4, 378-385.

Randi, E., Lucchini, V. \& Cheong Hoong Diong, 1996. Evolutionary genetics of the Suiformes as reconstructed using mtDNA sequencing. Journal of Mammalian Evolution, 3, 163-194.

Shimamura, M., Yasue, H., Ohshima, K., Abe, H., Kato, H., Kishiro, T., Goto, M., Munechika, I. \& Okada, N. 1997. 
Molecular evidence from retroposons that whales form a clade within even-toed ungulates. Nature, 388, 666-670.

Shimamura, M., Abe, H., Nikaido, M., Ohshima, K. \& Okada, N. 1999. Genealogy of families of SINEs in cetaceans and artiodactyls: the presence of a huge superfamily of

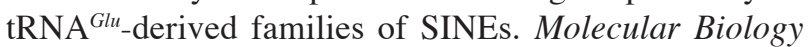
and Evolution, 16, 1046-1060.

Simpson, G.G. 1945. The principals of classification and a classification of mammals. Bulletin of the American Museum of Natural History, 85, 1-350.

Sisson, S. \& Grossman, J. 1953. The Anatomy of the Domestic Animals, 4th Edition, W.B. Saunders, Philadelphia and London, 972 pp.

Shedlock, A., Milinkovitch, M. \& Okada, N. 2000. SINE evolution, missing data, and the origins of whales. Systematic Biology, 49, 808-817.

Spaan, A. 1996. Hippopotamus creutzbergi; the case of the Cretan hippopotamus. In: Pleistocene and Holocene fauna of Crete and its first settlers (Ed. D.S. Reece). Monographs in World Archaeology, Prehistory Press, 28, 99-110.

Speke, J.H. 1863. Journal of the Discovery of the Source of the Nile. J. M. Dent and Sons, Limited (No. 50 of the Everyman's Library) p. 223.

Stehlin, H.G. 1899-1900. Über die Geschichte des SuidenGebisses. Abhandlungen der Schweizerische Paläontologische Gesellschaften, 26-27, 1-527.

Stehlin, H.G. 1908. Die Säugetiere des Schweizerischen Eocäns. 5 teil (Suidae). Abhandlungen der Schweizerische Paläontologische Gesellschaften, 35, 1-696.

Sudre, J. 1995. La Garouillas et les sites contemporains (Oligocène, MP 25) des phosphorites du Quercy (Lot, Tarn-et-Garonne, France) et leurs faunes de vertébrés. Palaeontographica Abteilung A, 236, 205-256.

Swinhoe, R. 1870. On a new deer from China. Proceedings of the Zoological Society of London, 1870, 88-92.

Thenius, E. 1969. Phylogenie der Mammalia, Stammesgeschichte der Säugetiere. Berlin, Walter de Gruyter and Co.

Theodor, J.M. \& Foss, S.E. 2006. Deciduous dentitions of Eocene Cebochoerid artiodactyls and cetartiodactyl relationships. Journal of Mammalian Evolution, 12,161181.

Thewissen, J.G.M., Russel, D., Gingerich, P. \& Hussain, S.T. 1983. A new dichobunid artiodactyl (Mammalia) from the Eocene of north-west Pakistan. Dentition and Classsification. Proceedings of the Koninklijke Nederlandse Akademie van Wetenschappen, 86, 153-180.

Thewissen, J.G.M., Madar, S.I. \& Hussain, S.T. 1998. Whale ankles and evolutionary relationships. Nature, 395, 452.

Thewissen, J.G.M., Williams, E.M., Roe, L.J. \& Hussain, S.T. 2001. Skeletons of terrestrial cetaceans and the relationship of whales to artiodactyls. Nature, 413, 277-281.

Thewissen, J.G.M., Cooper, L.N., Clementz, M.T., Bajpai, S. \& Tiwari, B.N. 2007. Whales originated from aquatic artiodactyls in the Eocene epoch in India. Nature, 450, 1190-1194.
Trouessart, E. 1904. Catalogus mammalium, Quinquennale I Supplementum.

Tsubamoto, T., Takai, M., Egi, N., Nobuo, S., Soe, T.T., Aye, K.A., Aung, N.S. \& Tin, T. 2002. The Anthracotheriidae (Mammalia; Artiodactyla) from the Eocene Pondaung Formation (Myanmar) and comments on some other anthracotheres from the Eocene of Asia. Palaeontological Research, 6, 363-384.

Tsujikawa, H. 2005. The updated Late Miocene large mammal fauna from Samburu Hills, northern Kenya. African Study Monographs, Supplement, 32, 1-50.

Ursing, B.M. \& Arnason, U. 1998. Analyses of mitochondrial genomes strongly support a hippopotamus-whale clade. Proceedings of the Royal Society of London, B265, 2251-2255.

Ursing, B.M., Slack, K. \& Arnason, U. 2000. Subordinal artiodactyl relationships in the light of phylogenetic analysis of 12 mitochondrial protein-coding genes. Zoologica Scripta, 29, 83-88.

Weston, E.M. 2003. Fossil Hippopotamidae from Lothagam. In: Lothagam: The Dawn of Humanity in Eastern Africa (Eds. M.G. Leakey \& J.M. Harris). Columbia University Press, New York, 441-483.

Van der Made, J. 1996. Albanohyus, a small Miocene pig. Acta zoologica cracoviana, 39, 293-303.

Van der Made, J. 1997. Systematics and stratigraphy of the genera Taucanamo and Schizochoerus and a classification of the Palaeochoeridae (Suoidea, Mammalia). Proceedings of the Koninklijke Nederlandse Akademie van Wetenschappen, 100, 127-139.

Van der Made, J. 1999. Superfamily Hippopotamoidea. In: Miocene Land Mammals of Europe (Eds. G.E. Rössner \& K. Heissig). Pfeil Verlag, München, 203-208.

Van der Made, J., \& Han Defen, 1994. The Suiodea from the hominoid locality Lufeng (Yunnan, China). Proceedings of the Koninklijke Nederlandse Akademie van Wetenschappen, 97, 27-82.

Viret, J. 1961. Artiodactyla. In: Traité de Paléontologie, (Ed. J. Piveteau) Masson et Cie, Paris, 6 (1), 887-1021, 1038-1084.

Von Meyer, H. 1834. Die fossilen Zähne und knocken und ihre Ablagerung in der Gegend von Georgensmund in Bayern. Museum Senckenbergianum, 1, Supplement 4, i-viii, 1-126.

Xu, X., Janke, A. \& Arnason, U. 1996. The complete mitochondrial DNA sequence of the greater Indian Rhinoceros unicornis, and the phylogenetic relationship among Carnivora, Perissodactyla, and Artiodactyla (+ Cetacea). Molecular Biology and Evolution, 13, 1167-1173.

Zbyszewski, G. 1949. Les vertébrés du Burdigalien supérieur de Lisbonne, Service Géologique du Portugal, Lisbon, 1949, 1-77.

Manuscrito recibido: 28 de Septiembre, 2007 Manuscrito aceptado: 22 de Febrero, 2008 